

\section{वंरां सहं हैं है}

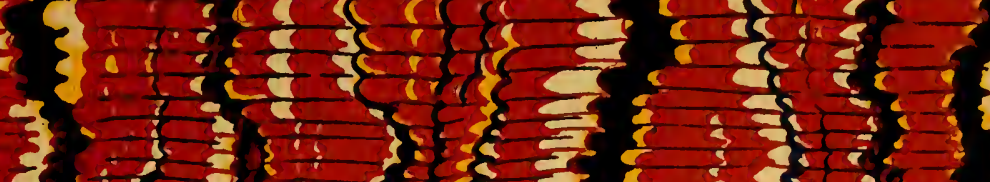
the

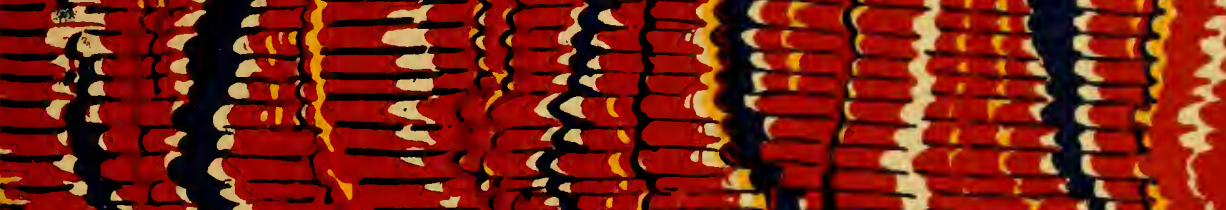
$=3: 52$ iर्धि दो

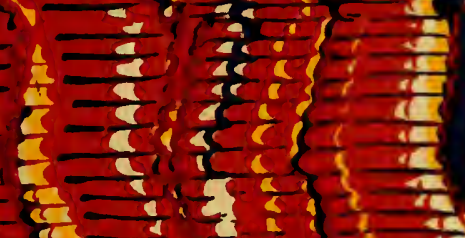

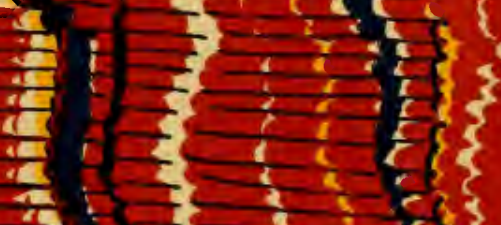
Iै।

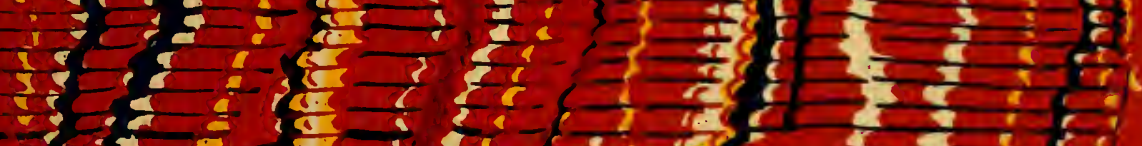

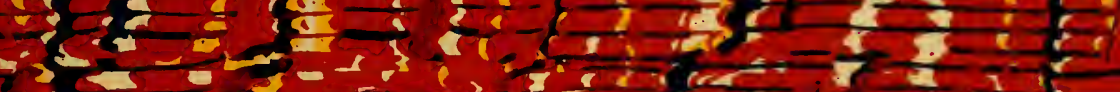

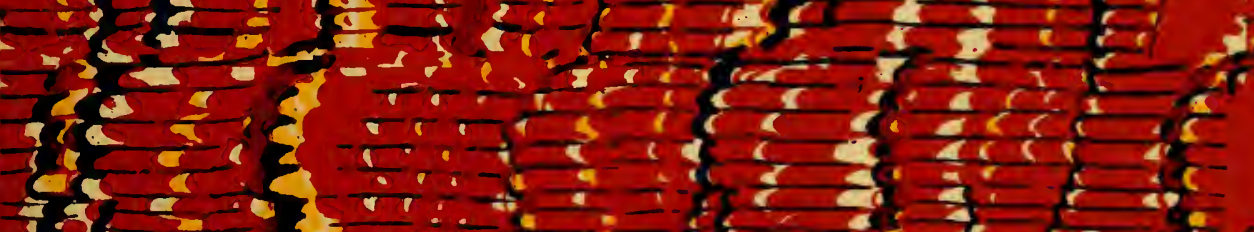
$\frac{3}{3}=2$ $5 x$ $\frac{1}{2}=$ $\frac{5}{3}=\frac{2}{3}$

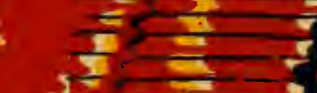

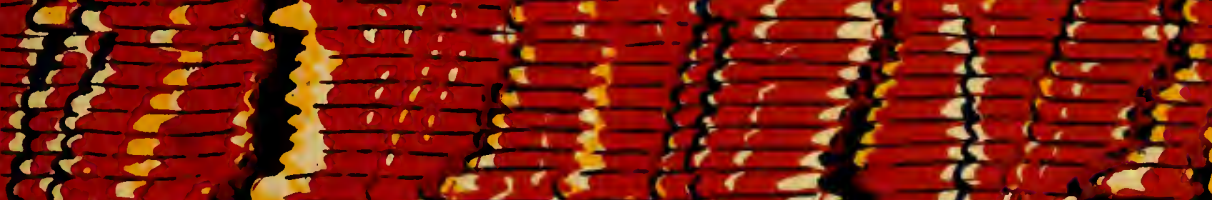

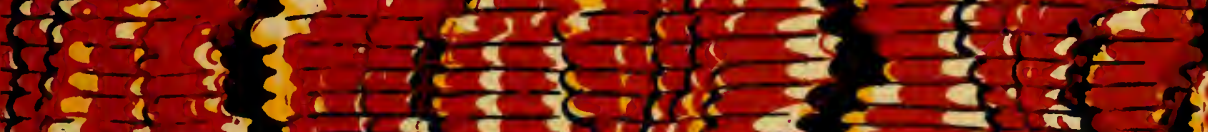

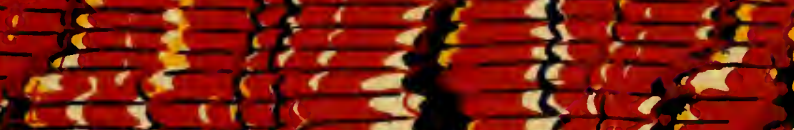

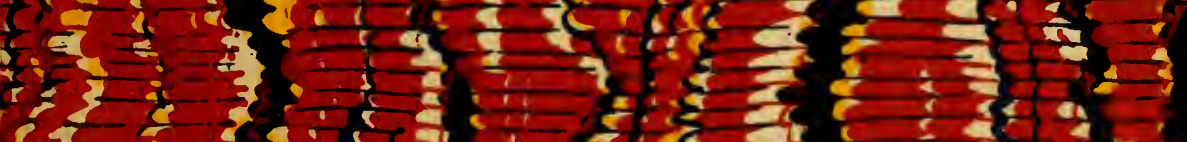
$2-\frac{1}{2}$ द 5 s.ics

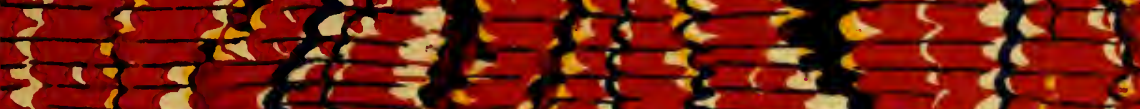

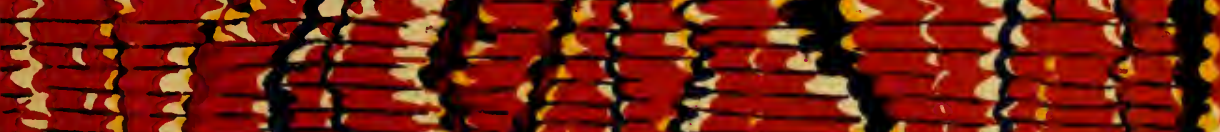

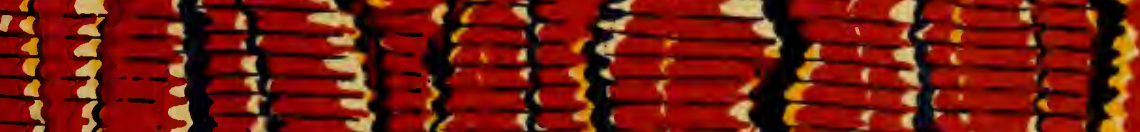
है
t

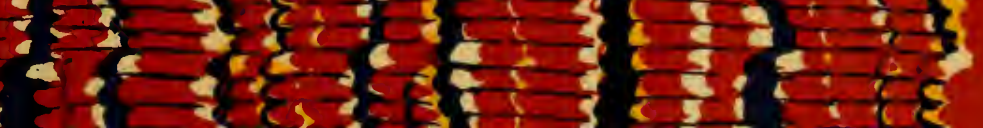







LELAND STANFORD JUNIOR UNIVERSITY PUBLICATIONS UNIVERSITY SERIES

No. 4

\section{Synopsis}

of the

\section{True Crabs (Brachyura) \\ of Monterey Bay \\ California}

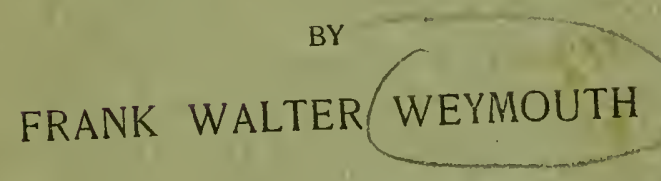

WITH PLATES I-XIV

[Published November 12, 1910]

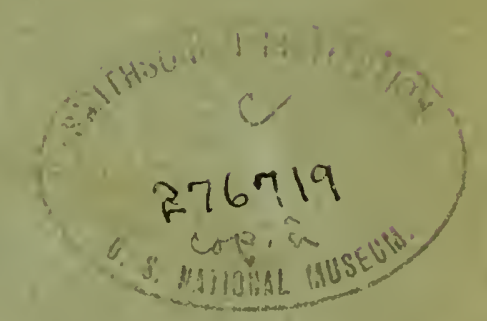

STANFORD UNIVERSITY, CALIFORNIA

PUBLISHED BY THE UNIVERSITY

I9IO 


\section{UNIVERSITY SERIES}

No. 1. Inheritance in Silkworms, I. Vernon L. Kellogg, Professor of Entomology. 89 pp., 4 plates. 1908. Price, $\$$ r.00.

No. 2. The Opisthobranchiate Mollusca of the Branner-Agassiz Expedition to Brazil. Frank Mace MacFarland, Professor of Histology. 105 pp., I9 plates. 1909. Price, \$1.00.

No. 3. A Study of the Normal Constituents of the Potable Water of the San Francisco Peninsula. John Pearce Mitchell, Assistant Professor of Chemistry. 70 pp., I map. 1910. Price, 50c. 


\title{
LELAND STANFORD JUNIOR UNIVERSITY PUBLICATIONS
} UNIVERSITY SERIES

$$
\text { No. } 4
$$

\section{Synopsis}

\author{
of the
}

\section{True Crabs (Brachyura) of Monterey Bay \\ California}

BY

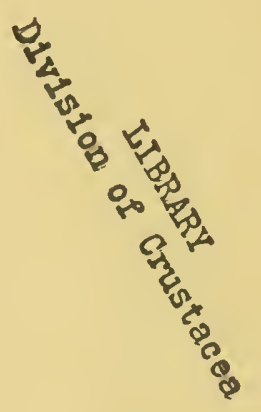

FRANK WALTER WEYMOUTH

WITH PLATES I-XIV

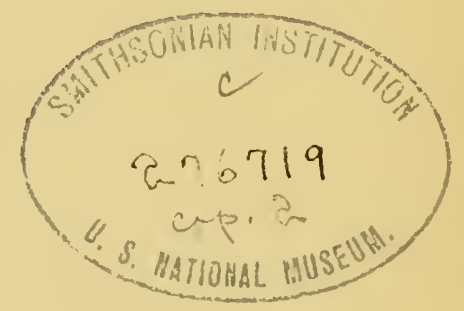




\section{TABLE OF CONTENTS.}

PAGE

Introduction . . . . . . . . . . . . . . . . . . . 5

Scope and purpose of paper . . . . . . . . . . 5

New species . . . . . . . . . . . . . . . . . 7

Species not previously reported from Monterey Bay . . . . 7 List of species treated . . . . . . . . . . . . . . . . 8

Key to the suborders of the order Decapoda . . . . . . . . II

Key to the tribes of the suborder Reptantia . . . . . . . . . II

Key to the families of the tribe Brachyura . . . . . . . . . I2

Brachyura of Monterey Bay . . . . . . . . . . . . . I4

Subtribe Dromiacea . . . . . . . . . . . . . . . I4

Superfamily Dromiidea . . . . . . . . . . . . . I4

Family Dromiidae . . . . . . . . . . . . 14

Subtribe Oxystomata . . . . . . . . . . . . . . . I8

Family Dorippidae . . . . . . . . . . I8

Family Leucosiidae . . . . . . . . . . 18

Family Calappidae . . . . . . . . . . . . . 19

Subtribe Brachygnatha . . . . . . . . . . . . . 2I

Superfamily Oxyrhyncha . . . . . . . . . . . . 2I

Family Parthenopidae . . . . . . . . . . . 2I

Family Inachidae . . . . . . . . . . . 21

Superfamily Brachyrhyncha . . . . . . . . . . 35

Family Cancridae . . . . . . . . . . . 35

Family Portunidae . . . . . . . . . . . . . 49

Family Pilumnidae . . . . . . . . . . . . . 50

Family Pinnotheridae . . . . . . . . . . 53

Bibliography . . . . . . . . . . . . 64

Explanation of plates . . . . . . . . . . . . . . 65 



\section{SYNOPSIS OF THE TRUE CRABS (BRACHYURA) OF MONTEREY BAY, CALIFORNIA}

In this paper are included all of the Brachyura or true crabs known from Monterey Bay or from points near enough to make their occurrence there probable, and it is hoped that the keys and figures here given will render easy their identification. It is intended that this shall be one of a series of papers of similar scope dealing with the fauna of Monterey Bay, with a view toward placing at the disposal of workers at the Marine Biological Laboratory an easy means of becoming acquainted with the invertebrates of that region. Preliminary work has been done in several groups, and in the case of the Anomura and the Macrura, the writer hopes to present reports in the near future.

Monterey Bay occupies an open semicircular indentation of the coast line, a little over one hundred miles south of San Francisco, measuring about twenty-five miles from Santa Cruz on the north to Point Pinos on the south, and perhaps ten miles from a line drawn between these two points to the mouth of the Salinas River on the east. The northern and eastern shores of the bay are low and sandy, but from a point near the town of Monterey to Point Pinos and thence south nearly to the town of Carmel, some ten miles, the coast is, with the exception of a few small sandy beaches, extremely rugged, furnishing innumerable rocky tide-pools that form an unusually rich collecting ground, not only for crustacea but for all kinds of invertebrates.

The Stanford Marine Biological Laboratory is located at Pacific Grove, about midway of the southern shore of the bay, and as this has been the central point for shore collecting, the greater part of the work has been confined to four or five miles of the coast, reaching from near Monterey to some distance south of Point Pinos, though a few trips have been made to points north or south of these limits.

Considerable dredging has been done at moderate depths, thirty fathoms and under, from a small launch. Off the eastern shore the bottom is sandy; this has been little worked, but has yielded some valuable specimens. Off the town of Monterey in the southeastern corner of the bay there is a large area of hard blue clay, rich in burrowing mollusks, which has proved a good field for crustacea, and here most of the dredging has been done. Near Point Pinos the bottom is rocky, and would undoubted- 
ly yield much to a more thorough use of the tangle than has yet been attempted.

The present work was begun at the Marine Laboratory during the summer session of 1906, when J. N. Procter and the writer, working under the direction of Dr. G. C. Price, made and indentified a considerable collection of crustacea. It has been finished at Stanford University under the guidance of Dr. H. Heath and Dr. W. K. Fisher, to whom as well as to Dr. G. C. Price, the writer is greatly indebted. The material upon which the work is based has been collected for the greater part by the writer during the three summers of 1906, 1907 and 1908, but includes as well the results of the collecting of numerous students at the Marine Laboratory, among whom the manuscript of the keys has been in use during the session of 1908 , and all specimens in the University collection known to have come from Monterey Bay.

The writer wishes to express his obligations to W. F. Allen of Pacific Grove for material, and especially to Miss M. J. Rathbun of the United States National Museum for much kind assistance in determining specimens and for the loan of material.

There has been much excellent work done on the west American crustacea, and the writer is particularly indebted to the papers of S. J. Holmes and Miss M. J. Rathbun. No attempt has been made to duplicate the full descriptions of Holmes, attention being confined to the noting of variations or other points of interest except in the case of a few species, whose descriptions are incomplete or not easily accessible, and which have been treated at some length.

The writer has followed Borradaile (Annals and Magazine of Natural History, Seventh series, vol. I9, p. 457) in the use of the suborders Natantia and Reptantia instead of Macrura and Brachyura (or Macrura, Anomura and Brachyura) and in the inclusion of the Dromiidae with the Brachyura instead of with the Anomura. The keys to suborders and tribes are taken from his paper with some modifications. In the arrangement of families, though not of species, Miss Rathbun (Decapod Crustaceans of the Northwest Coast of North America, Harriman Alaska Expedition, vol. Io) has been followed.

Fifty-two species are here treated. Of these, the occurence of fortythree is well established, six rest on doubtful records and three more are included because found in adjacent regions or for completeness. Of the forty-three species thirty-six are represented in the collection at hand. One new species is here described. The following lists set forth these facts more clearly. 
New species:

Dromidia segnipes.

Species not previously reported from Monterey Bay:

Randallia bulligera

Podochela hemphillii

Dasygyius tuberculatus

Rhodia parvifrons

Cycloxanthops novemdentatus

Lophopanopeus diegensis

? Pinnixa occidentalis 


\section{LIST OF SPECIES TREATED IN THE PRESENT PAPER}

Order Decapoda.

Suborder Reptantia.

Tribe Brachyura.

Subtribe Dromiacea.

Superfamily Dromiidea.

Family Dromiidæ.

I. Genus Dromidia

COLLECTED REPORTED

Subtribe Oxystomata.

I. D. segn
Oxystomata.
y Dorippidx.

Family Dorippidæ.

2. Genus Clythrocerus.

2. C. planus (Rathbun)................?

Family Leucosiidæ.

3. Genus Randallia.

3. R. ornata (Randall) .................

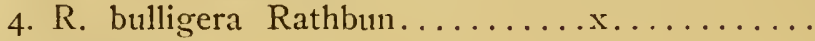

Family Calappidæ.

4. Genus Mursia.

5. M. gaudichaudii (Milne Edwards) x....... Subtribe Brachygnatha.

Superfamily Oxyrhyncha.

Fanily Parthenopidæ.

5. Genus Heterocrypta.

6. H. occidentalis (Dana) ................ Family Inachidæ.

6. Genus Podochela.

7. P. hemphillii (Lockington)

7. Genus Erileptus.

8. E. spinosus Rathbun..................?

8. Genus Anasimus.

9. A. rostratus Rathbun................. ?

9. Genus Dasygyius.

Io. D. tuberculatus (Lockington) ...x.........

Io. Genus Epialtus.

I I. E. bituberculatus Milne Edwards. ......... ?

I2. E. productus Randall............... 
I I. Genus Pugettia.

I3. P. gracilis Dana................

14. P. richii Dana..................

I2. Genus Mimulus.

I5. M. foliatus Stimpson...............

I3. Genus Lo.rorhynchus.

I6. L. grandis Stimpson.................

17. L. crispatus Stimpson................

I4. Genus Chorilia.

I8. C. longipes Dana..................

15. Genus Scyra.

I9. S. acutifrons Dana..................

16. Genus Rhodia.

20. R. parvifrons (Randall)

I7. Genus Chionoecetes.

2I. C. tanneri Rathbun................... Superfamily Brachyrhyncha.

Family Cancridæ.

18. Genus Cancer.

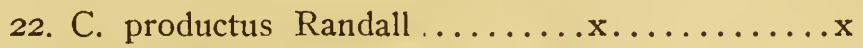

23. C. magister Dana......................

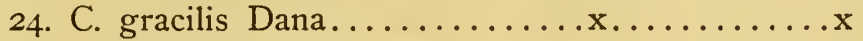

25. C. gibbosulus (de Haan) ................

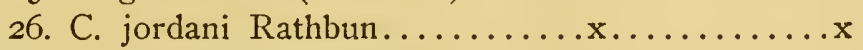

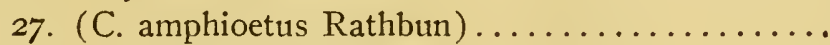

28. C. antennarius Stimpson.................

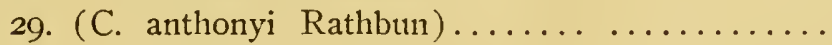

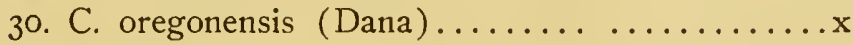

Family Portunidæ.

19. Genus Portunus.

31. (P. xantusii (Stimpson) )............?

Family Pilumnidæ.

20. Genus Cycloxanthops.

32. C. novemdentatus (Lock.)...............

21. Genus Lophopanopeus.

33. L. bellus (Stimpson) ..................

34. L. heathii Rathbun...................

35. L. leucomanus (Lock.)................

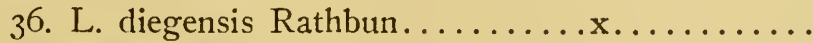

22. Genus Xanthias.

37. X. taylori (Stimpson) ................. 
Family Pinnotheridæ.

23. Genus Pinnotheres.

38. P. nudus Holmes.................. .

24. Genus Raphonotus.

39. R. subquadratus (Dana) ...............

25. Genus Pinnixa.

40. P. occidentalis Rathbun....... ?..........

4I. P. californiensis Rathbun.................

42. P. tubicola Holmes.......... ........ . .

43. P. littoralis Holmes................ .

44. P. longipes (Lock.).................. .

45. P. faba (Dana)......................

26. Genus Scleroplax.

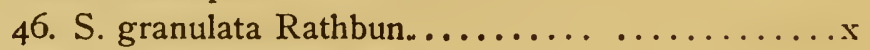

27. Genus Cryptophrys.

47. C. concharum Rathbun................ x

28. Genus Opisthopus.

48. O. transversus Rathbun................ Family Grapsidæ.

29. Genus Pachygrapsus.

49. P. crassipes Randall..................

30. Genus Hemigrapsus.

50. H. nudus (Dana) ......................

51. H. oregonsis (Dana) .................

31. Genus Planus.

52. (P. minutus (Linnæus) ) .............. ? 


\section{Key to the Suborders of The Order Decapoda.}

a. Rostrum seldom reduced or absent, if well developed almost invariably compressed. Body always compressed. First abdominal segment not much smaller than the rest. First antenna generally bears a scale at base; second antennal scale generally large. Legs slender (except sometimes a stout chelate limb or pair of limbs which may be any one of first three) with basipodite and ischiopodite never fused, only one fixed point in the carpo-propodal articulation. Abdominal limbs $x-5$ always present in full number, well developed, and used for swimming. Natantia

aa. Rostrum often reduced or absent, depressed if present. Body not compressed, generally depressed. First abdominal segment distinctly smaller than the rest. No scale on first antenna; that on second antenna never large, generally small or absent. Legs stout, the first usually, the others never, stouter than their fellows; basipodite and ischiopodite alinost always fused in the first pair, generally in others, two fixed points in the carpo-propodal articulation. Abdominal limbs I-5 often reduced or absent, not used for swimming.

Reptantia

\section{Key to the Tribes of the Suborder Reptantia.}

a. Carapace not fused with epistome; last thoracic sternum free, its legs reduced, often chelate, always differing from the third pair. Abdomen large and extended or reduced and loosely folded under carapace, generally (except in Lithodidæ) with biramous appendages on the sixth segment. Antennæ (second) well developed, situated external to eye, with long flagella and often a movable scale.

Anomura

aa. Carapace fused with epistome at sides and nearly always also in middle; last thoracic sternum fused with others, its legs never chelate, seldom markedly different from the others. Abdomen much reduced, symmetrical, closely folded beneath thorax, never with biramous appendages on sixth segment (only in Dromidæ is the sixth pair present even in a rudimentary condition). Antennæ (second) situated internal to eye seldom with long flagella, never with movable scale.

Brachyura 


\section{Key to the Families of the Tribe Brachyura.}

a. Second antennæ long (flagellum equal to more than half the width of the carapace); first antennæ without special fossettes, first abdominal legs of female present, uropods rudimentary or absent, female openings in coxæ of legs, gills numerous.

Subtribe DROMIACEA, Fam. Dromiidae

$a a$. Second antennæ short (never equal to half the width of the carapace)

first antennæ usually lodged in special fossettes, first abdominal legs of female wanting, uropods never present, female openings in sternum (rarely in coxæ), gills few.

b. Buccal frame triangular, narrowed forward; efferent branchial channels opening at middle of endostome.

Subtribe OXYSTOMATA

c. Last I or 2 pairs of legs reduced in size and articulated higher than preceding pairs, so as to lie on dorsal surface of body.

Fam. Dorippidae

cc. Legs normal in size and position.

d. Maxillipeds closing the buccal cavern; the palp hidden by the triangular merus.

Fam. Leucosiidae

dd. Maxillipeds not completely closing the buccal cavern; the palp always exposed.

Fam. Calappidac

$b b$. Buccal frame quadrate; efferent branchial channels opening at sides of endostome.

Subtribe BRACHYGNATHA

c. Carapace usually triangular, with pointed or spined rostrum;

the branchial region inflated, the hepatic region small; orbits usually incomplete. Superfam. Oxyrhyncha

d. Basal antennal joint very small and short, not reaching farther forward than posterior margin of orbit; hard basal joint of antennule reaching orbit and forming part of inferior margin. Chelipeds much longer and more massive than other legs.

Fam. Parthenopidac

dd. Basal antennal joint well developed, reaching at least to anterior margin of orbit, of the lower margin of which it forms the greater part; basal antennular joint usually soft and concealed in fossette, never reaching orbit. Chelipeds not markedly longer or more massive than other legs. Fam. Inachidae 
cc. Carapace without rostrum, usually broad, never with the hepatic region greatly reduced; orbits generally well enclosed.

Superfam. Brachyrhyncha

d. Carapace generally broader than long, wide and regularly arcuated in front; lateral margins markedly convergent behind. Frontal region not markedly broad, generally produced horizontally in lobes or teeth.

e. Antennules folded longitudinally, front with several teeth one of which is median; outer maxillipeds overlapping the endostome.

Fam. Cancridae

$e e$. Antennules folded transversely or obliquely transversely, front with or without median tooth; outer maxillipeds not overlapping endostome.

$f$. Last pair of legs usually modified for swimming, with the last two joints very broad and paddle-like. Anterolateral border sharply marked off from postero-lateral. Front with or without median tooth. Fam. Portunidae

$f f$. Last pair of legs not modified for swimming. Antero-lateral border of carapace not sharply marked off from postero-lateral. Front generally divided by a median notch.

Fam. Piluminiae

$d d$. Carapace usually quadrilateral; lateral margins nearly parallel. Frontail region usually broad, bent downwards and without teeth or sharp lobes.

e. Carapace often more or less membranaceous; front, orbits and eye-stalks usually very small; buccal frame arcuate in front. Species small, generally commensal. Fam. Pinnothcridae

$e e$. Carapace hard and firm; front, orbits and eye-stalks not markedly small; buccal frame quadrate in front.

f. Front usually markedly broad; eye-stalks of moderate size. Fam. Grapsidae

$f f$. Front of moderate width or very narrow; eyestalks often greatly elongated.

Fam. Ocypodidae 


\section{Tribe BRACHYURA.}

Subtribe Dromiacea.

Superfamily Drom HDEA.

Family DROMIIDÆ.

No representative of this family has been recorded, as far as I am aware, from the west coast of North America north of the Mexican boundary. Hypochoncha panamensis is recorded by Faxon* from the west coast of Panama, but beyond this I do not know that any of the Dromiidæ have been reported from Mexico or Central America. It is therefore no inconsiderable addition to our western crustacean fauna to record a new Dromid from Monterey Bay. Two specimens were obtained in the summer of 1906 while dredging in shallow water, and although special effort was made during the two following summers to obtain more material these remain the only examples. The species proves to be a very close relative of Dromidia antillensis Stimpson, and further knowledge of its distribution may show it to be one of the numerous pairs of species found on opposite sides of the isthmus.

\section{Genus DROMIDIA Stimpson.}

Dromidia Stimpson, Proc. Acad. Nat. Sci. Phila., p. 63, I858 (Type-Dromidia hirsutissima (Lamark)).

Stimpson in defining this genus says, $\dagger$ "In the sternum of the female the copulatory sulci are produced, and approximated at their extremities in a more or less tuberculiform projection situated between the bases of the chelipeds." According to Miss Rathbun this description should be modified, as the sulci do not always end in a single tubercle. In the specimen here described the sulci end in distinct tubercles, and it interesting to observe that in the most closely related form, $D$. antillensis, the single

* Faxon, Memoirs Harvard Mus. Comp. Zool., xviii, 237.

† Stimpson, Proc. Acad. Nat. Sci. Phila., 1858, 225.-Report on the Crustacea collected by the North Pacific Exploring Expedition, Smithsonian Miscellaneous Collections, No. I717, I70. 
tubercle there present shows, according to Henderson,* "a slight trace of bifurcation in front."

\section{Dromidia segnipes sp. nov.}

Plate I, figs. I-2.

Carapace pubescent, markedly convex, and about as long as wide. Stimpson describes Dromidia antillensis, the most closely related form, as "somewhat longer than broad" and gives the following measurements: "length of carapax, I.30; breadth, 1.28 inch." The specimen at hand is considerably smaller and is broader than long, measuring i 5 by $15.7 \mathrm{~mm}$., but these relative proportions may be found to vary with age, as Henderson * gives the measurements of an immature $D$. antillensis 13.5 long by $13.8 \mathrm{~mm}$. wide. Front tridentate, the inner angles of the orbits more prominent than the rostral point, so that the front seems divided by a deep rounded notch when seen from above. In $D$. antillensis these teeth are stated to be subequal. Supraorbital teeth considerably smaller and more acute than those of front. External angle of orbit prominent and bounded by a marked fissure, as in $D$. antillensis.

The antero-lateral margin of the carapace is four-toothed as in $D$. antillensis but the teeth are obscured to superficial examination by the pubescence. The most posterior, located just behind the cervical groove, is acute and directed forward ; the next anterior to this is the most prominent and forms the greatest width of the carapace, it is also acute; the next is smaller but still acute; these alone are visible from above. The most anterior is very low and rounded, resembling more the tubercle at the angle of the buccal cavern than the preceding teeth. In $D$. antillensis the three anterior teeth are said by Stimpson to be "subspiniform," and by Benedict $\uparrow$ to be "little more than enlarged granules." The tooth posterior to the cervical groove is also stated to be less acute than the others, which is not the case in the specimen at hand.

The pubescence of the carapace is somewhat longer and more dense in the frontal region and sparser in the branchial regions. On removing the pubescence the carapace is seen to be glabrous and definitely, though not deeply areolated. The cervical groove, the most prominent of the markings, runs from a point just anterior to the last antero-lateral tooth nearly to the middle of the posterior margin of the carapace, where it be-

* Henderson, Challenger Anomura, Part lxix, I2.

$\dagger$ Benedict, U. S. Fish Commission Bull. for 1900, ii, I32. 
comes indistinct. The lateral margins of the cardiac region anterior to the cervical groove are marked by distinct sulci, external to which are low elevations, the anterior border is marked by a much less definite sulcus concave in front. In the type (male) which was carrying what was apnarently a sand-encrusted ascidian, nearly all of the carapace lateral and posterior to the cervical groove, with the exception of the intestinal region, is membranaceous; while in the second specimen, a female, only the subbranchial region is uncalcified.

Antennæ prominent, the basal portion four-jointed, the basal joint wider than long, the green gland opening at its inner margin between two acute inwardly projecting tubercles, the second joint the longest, projecting far enough to be slightly visible from above, the last two joints small, subequal, inserted in a deep rounded notch in the antero-internal angle of the preceding joint, the flagellum sparingly ciliated, more than half the length of the carapace. Lower orbital margin ending in a prominent obtuse tooth next the basal portion of the antennæ. Basal joint of the antennule large, reaching about to insertion of last two joints of the antenna, last two joints subequal; the last with two unequal brushes of hairs at the tip; in the normal position the last two joints are almost entirely concealed.

Endostome with a low ridge on either side bounding the efferent branchial channels. External maxillipeds stout, the ischium slightly wider at the distal end and armed on the inner margin with a row of 7 or 8 conical, corneous-tipped spines, the merus rectangular, slightly shorter than the ischium, distally truncated, very slightly rounded, both corners square. Palp articulated to inner side of merus near tip, entirely visible when in normal position; exognath nearly reaching tip of merus, tapering but little.

Chelipeds hairy except tips of fingers, stout, ischium small without prominent armature, merus trigonal, all the angles denticulated, a wide transverse sulcus above paralleling the distal margin, carpus short and stout, denticulated at anterior angles, hand without any conspicuous spines or tubercles. In these characters it does not differ widely from Stimpson's description of $D$. antillensis. The tips of the fingers are calcareous, of a light flesh color, markedly excavated at the tip and armed with large triangular teeth which interlock at the tip but gape pronouncedly at the base.

Ambulatory legs hairy, less stout than chelipeds but hardly "slender" as in $D$. antillensis. The last pair are unfortunately missing in both specimens; of those remaining the first and second are the largest and differ little in size, they are unarmed with the exception of the dactyls which terminate in strong, curved, corneous spines and are further armed with three or four straight corneous spines on the lower margin. The third 
ambulatory leg is much smaller, reaching scarcely to the tip of the carpus of the preceding pair, the dactyl is more sharply curved and lacks the secondary spines, the inferior distal angle of the propodus is provided with a nearly straight spine which may be opposed to the dactyl, thus making the appendage subcheliform. The last pair were apparently entirely dorsal in position.

Abdomen of male seven-jointed, much constricted between the first and second segments and widest at distal end of second, from which it tapers evenly to the seventh, which is obtusely triangular. First segment the shortest, second, third, fourth, and fifth subequal, sixth and seventh increasingly longer. The penultimate joint is said to be long and slender in D. antillensis. The rudimentary uropods are present in a slight notch between the sixth and seventh segments, barely visible from the outside.

Abdomen of the female seven-jointed, much constricted between the first and second segments, and widest at the third, from which it tapers gradually to the seventh, which is evenly rounded. The median portion is raised, forming a rounded ridge, the whole evenly pubescent. The uropods are present as in the male. The sternal sulci extend from the base of the third pair of legs to the center of the sternum of the chelipeds, where they end in closely approximated but distinct low tubercles. Abdominal appendages present on all the segments.

Color in alcohol, yellowish tan, tips of chelipeds flesh color; color in life similar.

\section{MEASUREMENTS}

Length of carapace

Width of carapace

Length of antennal flagellum

$\begin{array}{ll}\text { MALE (TYPE) } & \text { FEMALE } \\ & \\ \text { I } 5.0 \mathrm{~mm} . & \text { I5.7 } \mathrm{mm} . \\ \text { I5.7 } & \text { I6.3 } \\ \text { I } 1.0 & 10.0\end{array}$

Type No. 478, cotype No. 479, Invertebrate Series, Leland Stanford Junior University Zoological Museum. 
Subtribe Oxystomata.

Family DORIPPID E.

Genus CLYTHROCERUS A. Milne Edwards \& Bouvier.

Clythrocerus A. Milne Edwards \& Bouvier, Bull. Mus. Hist. Nat. Paris, v, 387, 1899 (Type-Clythrocerus nitida A. Milne Edwards).

\section{Clythrocerus planus (Rathbun).}

Cyclodorippe plana Rathbun, Amer. Nat., xxxiv, 519, 1900.

Clythrocerus planus Rathbun, H. A. E., x, I68, I904.

"Catalina and possibly Monterey.... under 50 fathoms" (Rathbun). In the American Naturalist the footnote giving the type locality is erroneously attached to C. nitida A. Milne Edwards, an Atlantic form. I have seen no specimen of this species.

\section{Family LEUCOSIIDÆ.}

\section{Genus RANDALLIA Stimpson.}

Randallia Stimpson, Proc. Bost. Soc. Nat. Hist., vi, 85, 1857 ; Journ. Bost. Soc. Nat. Hist., vi, 47I, I857 (Type-Randallia ornata (Stimpson)).

Key to species.

a. Carapace of adult nearly smooth, young with unequal smooth tubercles, size large.

$R$. ornata

$a a$. Carapace of adult covered with nearly equal minutely spinous tubercles, size small.

R. bulligera

Randallia ornata (Randall).

Plate I, fig. 3 .

Ilia ornata Randall, Journ. Acad. Nat. Sci. Phila., viii, 129, 1839.

Randallia ornata Holmes, Occas. Papers Calif. Acad. Sci., vii, 100, I900, and synonymy.-Rathbun, H. A. E., x, I70, I904.

Represented in the collection by a few adults brought in by Chinese fisherman, and several immature specimens about $10 \mathrm{~mm}$. long. 


\section{Randallia bulligera Rathbun.}

Randallia bulligera Rathbun, Proc. U. S. Nat. Mus., xxi, 6r4, pl. xliv, fig. 6, 1898. -Holmes, Occas. Papers Calif. Acad. Sci., vii, Ior, I900-Rathbun, H. A. E., $\mathrm{x}, 170,1904$.

I have placed in this species two small specimens dredged from ten fathoms, measuring $8 \times 9 \mathrm{~mm}$. and $6.2 \times 7.2 \mathrm{~mm}$. respectively, which, though they do not tally in all points with the descriptions given by Holmes and Rathbun, agree in certain features and seem to be fairly distinct from specimens of $R$. ornata of the same size. The most marked difference is in the tubercles, which in these specimens are set close together and are fairly uniform in size, though with a few smaller ones interspersed, and present when dried and examined by a lens a thick coat of minute spines. When wet these spines are not noticeable and tend to give the tubercle a "pearly" appearance, so that they might easily be called "smooth" as in Holmes's description. In the young of ornata the tubercles are more scattered and of unequal sizes and show no spines. The pollex of the cheliped in ornata is about equal to the length of the palm, while in these specimens it is shorter. I can see no other prominent differences and as the specimens fail to show the prominent trilobing of the margin of the efferent branchial channels and the relative position of the posterior prominences mentioned by Rathbun and Holmes, I have felt some hesitation in calling them bulligera.

Randallia bulligera has been reported from Magdalena Bay and from off San Diego, but not previously from Monterey Bay.

Family CALAPPIDA.

\section{Genus MURSIA Desmarest.}

Mursia Desmarest, Consid. sur les Crust., I08, footnote, I825-Milne Edwards, Hist. Nat. Crust., ii, I09, 1837.

Thealia Lucas, Ann. Soc. entom. France, ser. 1, viii, 577, I839 (Type-Mursia cristamana de Haan).

\section{Mursia gaudichaudii (Milne Edwards).}

Platymera gaudichaudii Milne Edwards, Hist. Nat. Crust., t. ii, I8o, 1837.-Holmes, Occas. Papers Calif. Acad. Sci., vii, 99, 1900, and synonymy.-Rathbun, H. A. E., $x, 170,1904$. 
I have had the opportunity of examining two specimens, both males, in the possession of W. F. Allen, who said that they were obtained in considerable numbers by fishermen seining in moderately deep water on a muddy bottom off the mouth of the Salinas River. These agree well with Holmes's description, but possess a pair of very prominent tubercles on the sternum of the segment bearing the chelipeds, not mentioned by him.

I have followed Miss Rathbun* in uniting Platymera with Mursia.

*U. S. Fish Commission Bulletin for $1903,888$. 


\section{Subtribe BRACHYGNATHA.}

\section{Superfamily OXYRHYNCIIA.}

Family PARTHENOPID正.

Genus HETEROCRYPTA Stimpson.

Hetcrocrypta Stimpson, Ann. Lyc. Nat. Hist. N. Y., x, I02, I87I (Type-Hcterocrypta granulata (Gibbes)).

\section{Heterocrypta occidentalis (Dana).}

Plate II, figs. 4-5.

Cryptopodia occidcntalis Dana, Am. Journ. Sci. (2), xviii, 430, I854.-Rathbun, Am. Nat., xxxiv, 516, 1900.

Heterocrypta occidentalis Holmes, Occas. Papers Calif. Acad. Sci., vii, 44, I900, and synonymy.-Rathbun, H. A. E., x, I70, 1904.

Represented in the collection by a considerable number of specimens, all dredged from moderate depths-ten to fifteen fathoms.

The rostrum in the younger specimens is rather more acute than in the adult and there is also considerable pubesence along the angles of the chelipeds and especially in the branchial and frontal regions, sometimes covering the greater part of the carapace, while the carapace of the adult is commonly smooth. As shown in the figures, the middle of the posterior margin of the carapace is more prominently rounded in the female than in the male.

Color in life: tips of tubercles white, ridges bearing tubercles light purplish, remainder of carapace mottled with numerous minute spots of white and purplish, giving a pink effect which often closely approaches white. Ambulatory legs usually a light yellow. Color in alcohol not markedly different.

\section{Family INACHID王.}

Specimens of all the species of Inachidæ here treated, II in number, have been available for examination, and considerable pains has been 
taken in the construction of keys, as this family usually proves troublesome to the novice, chiefly, it would seem, because of the characters made use of in keys, which are commonly, and almost necessarily, inaccessible or indefinite. The degree of completeness of the orbit, though uncloubtedly one of the most obvious of certain modifications involving the greater part of the head region, is generally used in a comparative manner as "more" or "less complete," which except to the person familiar with the forms is little better than useless. When present the orbit seems to be formed by the development of the pre- and post-ocular spines and by the expansion of the basal antennal joint. Of these the post-ocular spine is the most important; absent or distant from the eye in forms like Podochela and Erileptus, it becomes, in Chionoecetes and allied species, cup-shaped, and into this cavity the eye is retracted. I have attempted to make use of this character in the generic key, which follows in part that of Miss Rathbun on this group.* A second key based on more obvious and accessible characters and including the species is given as an additional aid.

Some interesting correlations were noted in the series, which though probably not unknown, I have not seen pointed out before. The length of the rostrum is correlated, not only, as might be expected, with the length of the carapace, but also with the length of the antennæ. The flagellum is usually somewhat shorter than the rostrum and corresponds quite closely to it in length; this is especially noticeable in comparing a form with a long slender rostrum as Chorilia with one having a short rostrum, as Chionoecetes. In a few cases (Mimulus) the antennæ exceed the rostrum. As follows from the length, the antennæ correspond in stoutness with the rostrum; but in addition, those species having markedly flattened rostrums are found to have flattened antennæe (Scyra, Pugcttia) while those with long cylindrical horns forming the rostrum have cylindrical antennæ (Chorilia).

I have followed Miss Rathbun in ignoring, as in the report on the Decapods of the Harriman Expedition, the subfamilies of this group, which seem, at least on this coast, to be of little service and incapable of sharp distinction.

*Am. Nat., xxxiv, 503-520, 1900. 
Key to Genera of Inachide Found in Monterey Bay.

a. Length of basal antennal joint (measured from raised margin of endostome to insertion of free joints) greater than, or equal to, the combined width of the same joints and that portion of the epistome or antennular fossettes lying between them, measured from bases of eye-stalks (middle of lower orbital margin).

$b$. Post-ocular spine inconspicuous and distant from eye.

c. Chelipeds fairly short and stout (dactyl about equal to palm), no supraocular spine.

Podochela

cc. Chelipeds long and slender (dactyl equal to about one-third palm), a prominent supra-ocular spine.

Erileptus

$b b$. Post-ocular spine prominent and close to eye.

c. A prominent, acute supra-ocular spine.

Anasimus

cc. Upper margin of orbit prominent, but without a spine.

Dasygyius

aa. Length of basal antennal joint less than distance between lower orbital margins (usually in the proportion of 2 to 3 ).

$b$. Post-ocular spine, if present, with anterior face convex or flattened so that cornea of retracted eye is always visible from above; exognath of outer maxilliped widest in distal half, tapering abruptly.

c. Lateral margins of carapace not markedly flattened or produced.

d. Surface of carapace smooth or undulated. Epialtus $d d$. Surface of carapace with spines or tubercules. Pugettia $c c$. Lateral margins of carapace markedly flattened and produced.

Mimulus

$b b$. Post-ocular spine cupped or with dense growth of hair on anterior face so that cornea of retracted eye is partially concealed from above; exognath of outer maxilliped widest in basal half, tapering gradually.

c. Post-ocular spine flattened and densely hairy on anterior face.

Loxorhynchus

cc. Post-occular spine deeply cupped on anterior face and without hairs.

d. A supra-ocular spine present. 
$e$. Rostrum composed of two long, slender, cylindrical horns.

$e e$. Rostrum composed of two short, flattened horns.

$f$. Outer margin of basal antennal joint flattened and produced, not spiny.

Scyra

$f f$. Outer margin of basal antennal joint not produced, spiny.

Rhodia

$d d$. No supra-ocular spine.

Chionoecetes

Key to Species of Inachide Found in Monterey Bay.

a. Rostrum simple.

b. Rostrum slender; ambulatory legs slender, long (equal to at least twice the width of carapace).

c. Chelipeds long, slender; dactyl about one-fourth total length of hand.

Erileptus spinosus

$c c$. Chelipeds moderately short and stout; dactyl about one-half total length of hand.

d. Carapace much elongated in front, depressed, not spiny, rostrum long. Podochela hemphillii

dd. Carapace not elongated in front, not depressed, rostrum short.

$e$. Acute supra-ocular spine, low tubercle on first abdominal joint. Anasimus rostratus

ee. No acute supra-ocular spine, prominent spine on first abdominal joint.

Dasygyius tuberculatus

$b b$. Rostrum stout, blunt; ambulatory legs short (less than twice the width of carapace). No spines on carapace.

aa. Rostrum bifid.

Epialtus bituberculatus

$b$. Rostral horns short or moderate (never exceeding one-fourth the total length of carapace), stout, more or less flattened.

c. Surface of carapace more or less undulated, smooth.

d. Margin of carapace not markedly thin and produced.

Epialtus productus

$d d$. Entire margin of carapace thin and produced in a leaflike expansion.

Mimulus foliatus 
$c c$. Surface of carapace markedly tubercular or spiny.

$d$. Carapace sub-pyriform or lyrate, rostrum moderate or long (one-fourth to one-sixth total length of carapace).

e. Rostral horns extremely flattened and leaf-like, not markedly divergent in adult.

Scyra acutifrons

$e e$. Rostral horns never greatly flattened, more or less divergent.

$f$. Carapace undulated, with few moderate tubercles.

g. Post-ocular spine and first antero-lateral tooth united by a leaf-like expansion of the carapace. Pugettia gracilis

gg. Post-ocular spine and first antero-lateral tooth acute and distinct. Pugettia richii

$f f$. Carapace with numerous or very prominent tubercles.

g. Tubercles small and numerous, carapace markedly convex. Loxorhynchus grandis

gg. Tubercles comparatively few, large and prominent, carapace not convex.

Loxorhynchus crispatus

$d d$. Carapace sub-orbicular, rostrum very short (one-ninth or one-tenth of total length of carapace).

e. Ambulatory legs long (equal to twice the width of carapace), no supra-ocular spine.

Chionoecetes tameri

ee. Ambulatory legs moderate (about equal to once and a half the width of carapace), an acute supra-ocular spine. Rhodia parvifrons

$b b$. Rostral horns long (about one-third the total length of carapace), slender, cylindrical.

Chorilia longipes 


\title{
Genus PODOCHELA Stimpson.
}

Podochela Stimpson, Ann. Lyc. Nat. Hist. N. Y., vii, 194, 1860.

Coryrhynchus Kingsley, Pro. Acad. Nat. Sci. Phila., 384, I879 (Type-Podochela grossipes Stimpson).

\section{Podochela hemphillii (Lockington).}

\author{
Plate II, fig. 6.
}

Microrhynchus hemphillii Lockington, Proc. Calif. Acad. Sci., vii, 30, 1877.

Podochela hemphillii Holmes, Occas. Papers Calif. Acad. Sci., vii, 17, 1900, and synonymy.-Rathbun, H. A. E., I7I, 1904.

A single specimen of this genus was dredged in the summer of 1906 , and though special effort was made to obtain more, none were found during either of the following summers. The specimen at hand differs in no essential respect from Holmes's rather full description of $P$. hemphillii except in the length of the rostrum. This feature is not very definitely stated by Holmes, who says that the rostrum "varies considerably in length, being sometimes broadly and sometimes narrowly triangular." In the figure given by Miss Rathbun the length of the rostrum (measured from the tip to the supra-ocular spine) is about one-fourth of the total length of the carapace, while in the Monterey specimen the rostrum equals about two-fifths of the total length. Miss Rathbun, who has examined the specimen, thought that it might prove a new species, but I hesitate to separate it on the single character of the length of the rostrum without a considerable series for comparison, especially since a specimen from Catalina Island (the only other Podochela at hand) shows a rostrum in some degree intermediate. Further material may prove it distinct, but for the present it seems best to list it as $P$. hemphillii, a record which materially increases its range, which as given by Miss Rathbun is "from San Luis Obispo, Cal., to Gulf of California."

\section{Genus ERILEPTUS Rathbun.}

Erileptus Rathbun, Proc. U. S. Nat. Mus., vol. xvi, 227, 1893 (Type-Erileptus spinosus Rathbun). 


\section{Erileptus spinosus Rathbun.}

Plate III, fig. 7 .

Erileptus spinosus Rathbun, Proc. U. S. Nat. Mus., xvi, 277, 1893.-Holmes, Occas. Papers Calif. Acad. Sci., vii, 2I, 1900.-Rathbun, H. A. E., x, I7I, pl. x, fig. I, I904.

This and the following species are included on the range given by Miss Rathbun from specimens collected by W. H. Dall in "southern California (either at Catalina Harbor or Monterey)." I have examined a specimen kindly loaned by Miss Rathbun and one obtained at Catalina by S. S. Berry. Though I have seen no specimens from Monterey, it is not at all improbable that it may occur there, in view of the number of spider crabs previously recorded only from the south (Podochela, Rhodia parvifrons, Dasygyius tuberculatus) which have been obtained during a comparatively small amount of collecting.

\section{Genus ANASIMUS A. Milne Edwards.}

Anasimus A. Milne Edwards, Crust. Reg. Mex., 350, I880 (Type-Anasimus fuga.x A. Milne Edwards).

\section{Anasimus rostratus Rathbun.}

Anasimus rostratus Rathbun, Proc. U. S. Nat. Mus., xvi, 277, 1893-Rathbun, H. A. E., $x, 171$, pl. $x$, fig. 4 , I904.

As before stated, this species is included on Miss Rathbun's authority. I have examined a specimen from the southern part of the state which she kindly loaned.

\section{Genus DASYGYIUS Rathbun.}

Microrhynchus Bell, Proc. Zool. Soc. London, 88, I835 (Preoccupied). Neorhynchus A. Milne Edwards, Crust. Reg. Mex., 350, I880 (Preoccupied). Dasygyius Rathbun, Proc. Bio. Soc. Wash., xi, I64, 1897 (Type-Dasygyius gibbosus (Bell)).

\section{Dasygyius tuberculatus (Lockington).}

Plate III, fig. 8.

Inachus tuberculatus Lockington, Proc. Calif. Acad. Sci., vii, 30, 1877.

Dasygyius tuberculatus Holmes, Occas. Papers Calif. Acad. Sci., vii, 27, I900, and synonymy.-Rathbun, H. A. E., 172, pl. x, fig. 3, 3a, 1904. 
A single male specimen was dredged from 45 fathoms. As this species was previously reported from San Diego and Alamitos Bay, this is a material increase of range.

\section{Genus EPIALTUS Milne Edwards.}

Epialtus Milne Edwards, Hist. Nat. Crust., i, 344, I834 (Type-Epialtus bituberculatus Milne Edwards).

Key to species.

a. Rostrum entire, no post-ocular spine.

E. bituberculatus

aa. Rostrum bifid, a post-ocular spine.

E. productus

\section{Epialtus bituberculatus Milne Edwards.}

Epialtus bituberculatus Milne Edwards, Hist. Nat. Crust., i, 345, pl. I5, fig. II, I834. -Rathbun, H. A. E., x, 173, 1904, and synonymy.

"Southern California (either Catalina Harbor or Monterey)" Rathbun. Its occurrence seems very doubtful; if found it should be easily distinguished by its small size, as compared with E. productus, and its entire rostrum.

\section{Epialtus productus Randall.}

Plate III, fig. 9.

Epialtus productus Randall, Journ. Acad. Nat. Sci. Phila., viii, Iro, 1839.-Holmes, Occas. Papers Calif. Acad. Sci., vii, 22, I900, and synonymy.-Rathbun, H. A. E., $x, 173,1904$.

This species, next to Cancer antennarius and Cancer productus which probably exceed it in weight, is the largest of the common shore crabs of Monterey Bay and is one of the few on the coast which aspire to the dignity of a common name, being called the "kelp crab" because, according to Holmes it is usually found on kelp which it closely resembles in color. The young are common along shore chiefly among the seaweed, but most of the adults obtained have come from the piles of the Monterey wharves, though it is found on floating kelp and on buoys. It is often affected with a sacculina, and seems to be the only species commonly so parasitized, as I have examined many specimens of other species and have never found a sacculina. 
Color in life varies from dark brown to tan, the lighter shades being found in young and apparently in recently moulted individuals in which also the dark spots mentioned by Holmes are inconspicuous or absent. Underparts reddish, often a bright brick red, sometimes with light markings on the coxæ of the ambulatory legs and on the external maxillipeds.

The following are the measurements of a large male and female.

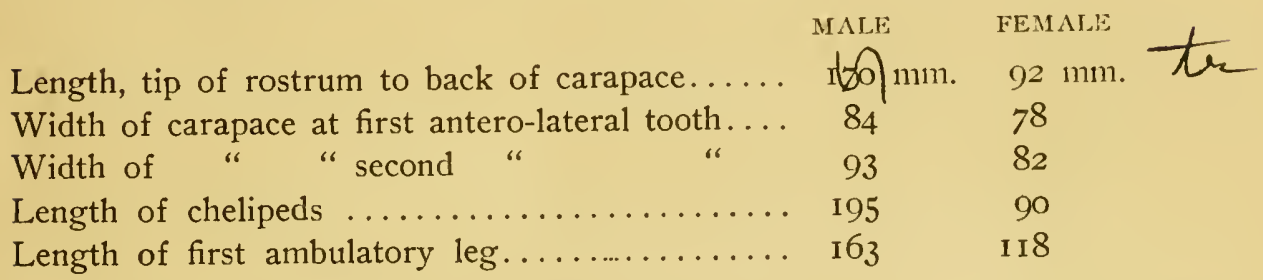

(Epialtus muttallii Randall - distinguished from E. productus by much less prominent lateral teeth and the absence of the postocular tooth -occurs at San Diego and Santa Barbara and may be found to extend as far north as Monterey.)

\section{Genus PUGETTIA Dana.}

Pugettia Dana, Amer. Journ. Sci. and Arts, ser. 2, vol. xi, 268, I851 ; U. S. Explor. Expd., Crust., xiii, 84, 1852 (Type-Pugettia gracilis Dana).

Key to species.

a. Post-ocular spine and first antero-lateral tooth united by a leaf-like expansion of the carapace.

$P$. gracilis

aa. Post-ocular spine and first antero-lateral tooth acute and distinct. P. richii

\section{Pugettia gracilis Dana.}

Plate IV, fig. Io.

Pugettia gracilis Dana, Am. Journ. Sci. (2), xi, 268, 1851--Holmes, Occas. Papers Calif. Acad. Sci., vii, 25, I900, and synonymy,-Rathbun, H. A. E., x, 173, 1904.

Aleutian Is. to southern California; Rathbun, Holmes. It seems rather surprising that among the large series of Pugettia examined this species should not appear though reported from both north and south of the Bay. I have examined specimens from Alaska. 


\title{
Pugettia richii Dana.
}

\author{
Plate IV, fig. II.
}

Pugettia richii Dana, Am. Journ. Sci. (2), xi, 268, I851.-Holmes, Occas. Papers Calif. Acad. Sci., vii, 24, 1900, and synonymy.-Rathbun, H. A. E., x, 173, 1904.

A series of about 50, though showing considerable variation, corresponds well with Holmes's description. The females differ from the males in possessing a more tumid carapace and less prominent lateral teeth though there is considerable variation among the males in these respects, and the young males often closely rescmble the females. The abdomen in young females is much narrower than in the adult form.

This species, the most common spider crab of Monterey Bay, is found abundantly between tides, usually where there is a growth of algae or coralline in company with young Epialtus productus which it resembles in habit, being slow of motion and clinging tenaciously to the seaweed when disturbed. The young, together with those of numerous other species, are found among the roots of the eel-grass often in the burrows of the pistol-crab (Crangon) which abound in these situations. Specimens were also obtained by dredging in shallow water- -5 to $I_{5}$ fathoms. It is frequently much overgrown with hydroids and coralline.

Color in life red, varying from bright to dark and often closely matching certain of the encrusting corallines. In alcohol the color fades to a dull tan.

The largest specimen in the collection is a male measuring $40 \mathrm{~mm}$. from tip of rostrum to back of carapace and $30 \mathrm{~mm}$. in width between the tips of the posterior teeth ( $25 \mathrm{~mm}$. between their bases).

Egg-bearing females were obtained in June, July and in the early part of January.

\section{Genus MIMULUS Stimpson.}

Mimulus Stimpson, Ann. N. Y. Lyc. Nat. Hist., vii, 200, 1860 (Type-Mimulus foliatus Stimpson).

\section{Mimulus foliatus Stimpson.}

Plate IV, figs. I2-I3.

Mimulus foliatus Stimpson, Ann. N. Y. Lyc. Nat. Hist., vii, 200, pl. iii, fig. I, 1860.Holmes, Occas. Papers Calif. Acad. Sci., vii, 23, I900, and synonymy.-Rathbun, H. A. E., x, 173, 1904.

Represented in the collection by numerous specimens, mostly young, 
dredged from moderate depths -5 to 12 fathoms. It is found alongshore with $P$. richii, but is less numerous.

There seems to be considerable variation in the shape of the two lateral teeth and in the relative widths at these two points.

"Color a dull purplish, the legs crossed by light bands," Holmes. The young and even mature (egg-bearing) individuals show considerable variation in color, being in general tan or light reddish with the lateral expansions and marks on the cardiac region lighter, in some cases almost white. One specimen had the entire surface of the carapace-except the rostrum-the abdomen and the chelipeds clear white, while the remainder of the legs and the rostrum were bright red. The legs in the majority show a more or less distinct banding. The adults are often partially covered by a growth of bryozoa or sponge.

\section{Genus LOXORHYNCHUS Stimpson.}

Loxorhynchus Stimpson, Proc. Bost. Soc. Nat. Hist., vi, 84, 1857, Journ. Bos. Soc. Nat. Hist., vi, 45I, 1857 (Type-Loxorhynchus grandis Stimpson).

Key to species.

a. Carapace with numerous nearly equal tubercles, sparingly hairy or smooth in adult. L. grandis aa. Carapace with 9 to 12 very prominent tubercles; covered with a short thick felt-like coat of hair.

L. crispatus

\section{Loxoryhnchus grandus Stimpson.}

\section{Plate V, fig. I4.}

Loxorynchus grandus Stimpson, Proc. Boston Soc. Nat. Hist., vi, 85, I857.-Holmes, Occas. Papers Calif. Acad. Sci., vii, 29, I900, and synonymy.-Rathbun, H. A. E., $x, 175,1904$.

Represented in the collection by two large males brought in by Monterey fishermen from "deep water." The fingers of the cheliped gape at the base, and there is a large blunt tooth on the dactyl which projects into this space. The measurements of the specimen figured are as follows :

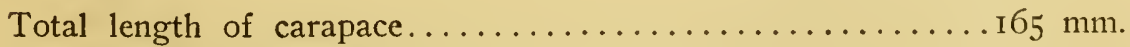

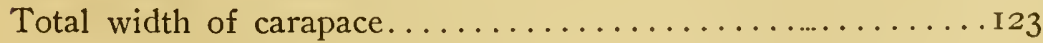

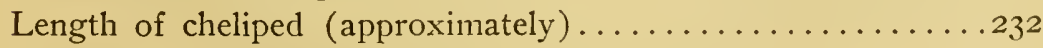

Length of first ambulatory leg (approximately)...........268 
Loxorhynchus crispatus Stimpson.

\author{
Plate V, fig. I5.
}

Lo.torhynchus crispatus Stimpson, Jour. Boston Soc. Nat. Hist., vi, 453, pl. xxii, figs. 2, 3 and 4, I857.-Rathbun, Proc. U. S. Nat. Mus., xvii, 74, I894.-Holmes, Occas. Papers Calif. Acad. Sci., vii, 30, 1900.-Rathbun, H. A. E., x, 175, 1904.

A series of 30 specimens (9 young) correspond well with Holmes's description, to which, however, the following points may be added. The anterior branchial tubercle is double, due to a smaller tubercle arising from the anterior internal flank. About midway between the posterior branchial tubercle and the cardiac-intestinal ridge, and lying nearly parallel to the latter, is a short slightly curved ridge or elongated tubercle. The tubercles of the carapace and of the legs, appearing, according to Miss Rathbun, "hemispherical with small shining points emerging," are in young or perfect specimens topped by a bunch of long clavate setæ, stouter and longer than those of the rostrum and uncurved. Similar setæ are found along the angles of the somewhat prismatic legs, along the posterior margin of the carapace, about the coxæ of the legs, and along the edge of the abdomen in the female.

The chelipeds of the male, as stated by Miss Rathbun, gape at the base and the dactyl is provided with a blunt tooth which projects into this space, while those of the female meet throughout their length.

The young ( 13 to $22 \mathrm{~mm}$.) differ considerably from the adults, the inner layer of plush-like hair being less marked, while more long hairs are scattered over the surface; the preorbital spine is more flattened at the base and directed more nearly horizontal, while the distance between their tips and the length of the rostrum in proportion to the length of the carapace is much greater than in the adult. Width between tips of preorbital spines is to length of the carapace as $I$ is to 3 in young and as I is to 5 in an old male. The tubercles in the young are less pointed and prominent than in the adult. Intermediate stages, however, connect all these characters. The horns of the rostrum are more divergent in the female than in the male.

The color of specimens in alcohol ranges from reddish brown to $\tan$; the carapace after removal of the hair often shows red markings, especially about the tubercles. 
Measurements of largest male in collection (the specimen figured) :

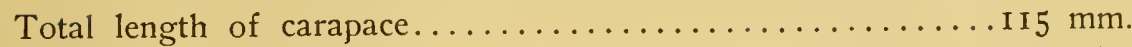

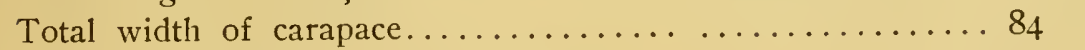

Length of cheliped (approximately)................

Length of first ambulatory leg (approximately).......... I6 “ "

This species is found from between tides to a depth of $50 \mathrm{ft}$. It is commonly known as the "moss crab" from the fact that it is generally completely covered with algæe, hydroids, bryozoa, ascidians, and the like so as to be "scarcely recognizable as a crab at all." It is, as might be expected, very sluggish in all its movements.

\section{Genus CHORILIA Dana.}

Chorilia Dana, Am. Journ. Sci., (2), xi, 269, I851 ; Crust. U. S. Expl. Expd., part I, 91, I852 (Type-Chorilia longipes Dana).

\section{Chorilia longipes Dana.}

Plate VI, fig. I6.

Chorilia longipes Dana, Am. Journ. Sci., (2), xi, 269, 1851.

Hyastenus (Chorilia) longipes Holmes, Occas. Papers Calif. Acad. Sci., vii, 33, 1900. Chorilia longipes Rathbun, H. A. E., x, I74, 1904.

No specimens of this species from a point nearer than San Diego are in the collection, although it is in all probabliity found in the bay.

\section{Genıs SCYRA Dana.}

Scyra Dana, Amer. Journ. Sci. and Arts, ser. 2, xi, 269, 1851 ; Crust. U. S. Expl. Expd., xiii (i), 80, 1852 (Type -Scyra acutifrons Dana).

\section{Scyra acutifrons Dana.}

Plate VI, fig. I7.

Scyra acutifrons Dana, Am. Journ. Sci., (2), xi, 269, I861.-Rathbun, Proc. U. S. Nat. Mus., xvi, 88, I893.--Holmes, Occas. Papers Calif. Acad. Sci., vii, 4 I, 1900.-Rathbun, H. A. E., x, 175, 1904.

This species (a series of about 30 ) shows, as stated by Holmes and Rathbun, great variation in the tuberculation of the carapace and in the form of the rostrum, as the following comparison of two large males of approximately the same size will show. 


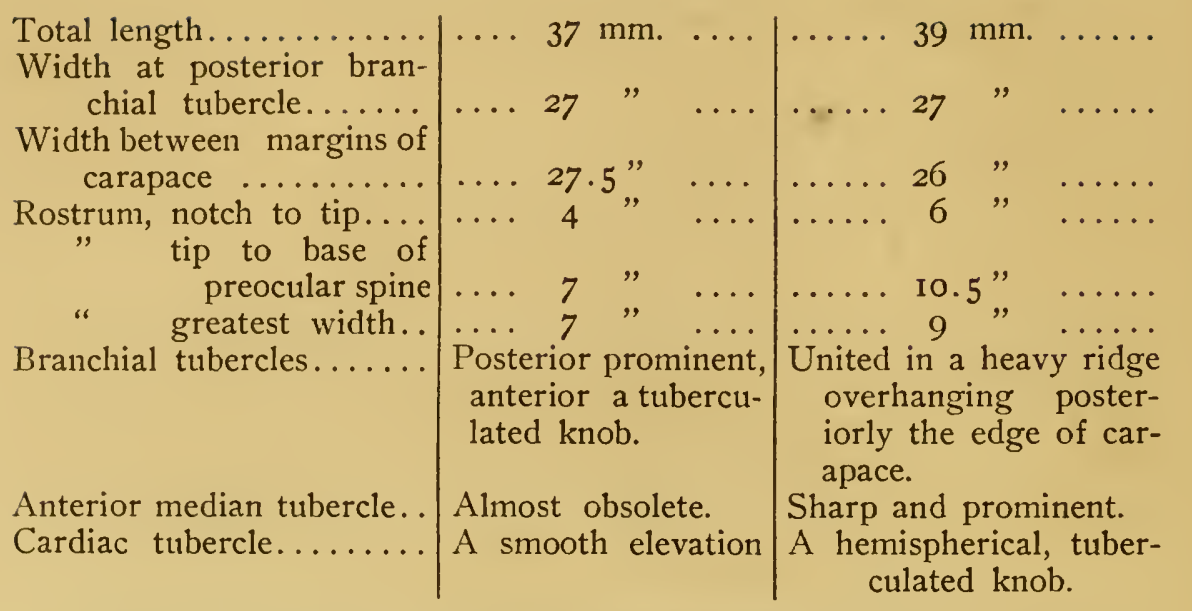

The young males are smoother than the adults and have narrower and more divergent horns to the rostrum, while the females have at times carapaces which are little more than undulated. The anterior external angle of the basal antennal joint is somewhat produced but seems hardly to form a spine as stated by Holmes. The "two spines or teeth on the outer margin" behind this are seldom prominent, the anterior being little more than an undulation of the margin.

This species is found from between tides to 20 fathoms, and like most of the spider crabs is generally so overgrown with sponges and other forms as to conceal the color.

All of the egg-bearing females are dated June.

\section{Genus RHODIA Bell.}

Rhodia Bell, Proc. Zool. Soc. Lond., I69, 1835 ; Trans. Zool. Soc. Lond., vol. ii, 43, I84I (Type-Rhodia pyriformis Bell).

\section{Rhodia parvifrons (Randall).}

Plate VII, fig. I8.

Herbstia parvifrons Randall, Journ. Acad. Nat. Sci. Phila., viii, I70, I839.-Holmes, Occas. Papers Calif. Acad. Sci., vii, 38, 1900.

Herbstia (Herbstiella) campacantha Holmes, op. cit. 37, and synonymy. Rhodia parvifrons Rathbun, H. A. E., 175, 1904, and synonymy.

Five specimens of this species have been obtained by the writer during 1908, all from a large tide-pool just south of the Point Pinos lighthouse. These agree well with Holmes's description except that the 
median tubercles are apparently less prominent, and that part of the tubercles, especially those in the posterior region, are tipped with setæ. All were much covered with sponges, of various kinds and the like. The color of the carapace is a light tan mottled with dark brown; the ambulatory legs are barred with reddish brown, and the chelipeds, with the exception of the light tips of the fingers, are a still more pronounced red.

This species has not been before recorded north of San Pedro.

\section{Genus CHIONOECETES Kröyer.}

Chionoecetcs Kröyer, Naturh. Tidskrift, (I), 2, 249, 1838 (Type-Chionoecctes opillio (Fabricius)).

\section{Chionoecetes tanneri Rathbun.}

Plate VII, fig. I9.

Chionoecetes tanneri Rathbun, Proc. U. S. Nat. Mus., xvi, 76, pl. iv, figs. I-4, I893. -Holmes, Occas. Papers Calif. Acad. Sci., vii, 40, I900.-Rathbun, H. A. E., $\mathrm{x}, \mathrm{I74}, 1904$.

Though there are no specimens in the University collection which are known definitely to have come from Monterey Bay, this species was obtained, according to Dr. Fisher, in large numbers by the "Albatross" while dredging at Monterey.

\section{Superfamily BRACHYRHYNCHA \\ Family CANCRID压.}

\section{Genus CANCER Linnæus.}

Cancer Linnaeus, Syst. Nat. ed. Io, vol. i, 625, 1758.

The genus Cancer appears to reach its highest development in the north Pacific, and on the west coast of the United States is represented, according to Miss Rathbun, by nine species. One of these-C. magisteris the common market crab of the whole coast, and with the exception of one or two other species of Cancer-C. productus, C. antcnnarius-is the only crab used as an article of food, so that the genus assumes considerable economic importance. Seven species have been reported from Monterey Bay: productus, magister, gracilis, gibbosulus, jordani, antennarius and oregonensis. I have obtained all these with the exception of oregonensis. 
As considerable interesting material was available in this genus I have included as far as possible all the species found on this coast in the keys: specimens of all of which with the exception of amphioetus have been examined. For six species-productus, jordani, gracilis, gibbosulus, antennarius, and anthonyi-sufficient young material was at hand to render possible the identification of immature specimens down to a size, in most cases, of $5 \mathrm{~mm}$. in width. A key is given for those measuring $20 \mathrm{~mm}$. and less in width, as the key to adults will not hold in many cases for the young and it is often very desirable to be able to place inmature specimens, some of which are very liable to confusion with the adults of smaller species. Satisfactory identification of small forms will not be possible in all cases without material for comparison; in fact the young of several species could be placed only through a complete growth series, a study of which disclosed some very interesting facts.

Although gracilis and gibbosulus differ so widely in the adult or even in specimens measuring $20 \mathrm{~mm}$., at a size of $5 \mathrm{~mm}$. they are almost indistinguishable, the young of gracilis showing the alternately large and small antero-lateral teeth and a well developed tenth tooth, both of which characters are absent in the adult of this species but present in the adultand young-of gibbosulus. The case of anthonyi and jordani is similar, here the young of anthonyi exhibit many of the characters of the adult jordani.

It is of course unsafe to rely too much upon the recapitulatory nature of these ontogenetic resemblances, but if even the slightest value is allowed them some very interesting light is thrown on the relationships of this group, promising much to a more extended study. The young of the six species mentioned, with the exception of productus, show many characters in common; they are pubescent, the antero-lateral teeth are alternately large and small and have spiny tips, the antennæ are large, stout and hairy, the chelipeds are more or less spiny, the carapace is long in proportion to its width,and the front is proportionally very wide. Some of these characters, such as the greater length of the carapace and the prominence of the front, are undoubtedly connected with the metamorphosis from the larval form, but others, for instance the alternately large and small teeth, which at least in gracilis appear immediately on molting from the megalops stage, seem hardly to be in any way connected with the metamorphosis or other ontogenetic changes. Of these five species only two-jordani and gibbosulus-retain the above mentioned characters in the adult, but here they are well marked. (See figures of these species.) Now gibbosulus was the type of the genus Trichocarcinus, and these 
characters, as pointed out by Miers (Proc. Zool. Soc. London, I879, p. 34) in speaking of that genus, indicate an undoubted relationship with Telmessus and Erimacrus, so that the placing of these troublesome genera in the Cancridæ, as is done by Miss Rathbun, is distinctly supported by the facts at hand. That gibbosulus is a Cancer there can be no doubt, in fact on the basis of youthful characters it might easily be considered the most typical of all the Pacific Coast species.*

It is unfortunate that no young specimens of oregonensis were available, as light might have been thrown on the relationship of this interesting form which differs so widely from other Cancers. As before mentioned, the young of productus, even in the smallest specimens at hand$6 \mathrm{~mm}$. wide-show no pubescence and no spiny tips or alternate arrangement of the antero-lateral teeth. The antennæ, though proportionally larger than in the adult, are not so large as in the other species and are not bushy; the front moreover retains its characteristic appearance and does not resemble that of any other species examined. Its relation to the other west coast Cancers would, therefore, appear to be rather distant.

\section{Key to Species of Cancer Found on West Coast.}

a. Antero-lateral and postero-lateral margins meeting at a distinct angle; carapace widest at 9 th (sometimes 8th) tooth. 9, Io or I I teeth.

$b$. Front markedly produced, formed of 5 subequal teeth.

C. productus

$b b$. Front not markedly produced, formed of 5 unequal teeth; outer teeth larger and more widely separated from the 3 median teeth than these from each other.

c. Antero-lateral teeth low (projecting less than I-3 the length of base) or irregular, not spiny-pointed; fingers of chelipeds not dark-tipped; merus of outer maxilliped elongated, rounded anteriorly. (These characters, except those of the fingers of chelipeds, do not hold in very small specimens.)

* As this paper is going to press I find an article by $\mathrm{J}$. T: Cunningham in the Proceedings of the Zoological Society of London ( 1898, p. 204) in which he figures an early stage of the common European Cancer ( $C$. pagurus) and points out the close relationship to the young of Atelecyclus which he considers should be included in the Family Cancridae. The figure of the youngest shows the alternation of large and small antero-lateral teeth mentioned above as characteristic of most species. This seems to furnish an additional proof of the wisdom of extending the genus Cancer. 
$d$. Carpus of cheliped with a single spine above at distal end; dactyls of ambulatory legs, especially those of last pair, much flattened. $\quad C$. magister $d d$. Carpus of cheliped with 2 spines, one above at distal end and a second below this on inner angle; dactyls of ambulatory legs slender, not flattened.

C. gracilis

$c c$. Antero-lateral teeth not low (projecting more than I-3 the length of base), often spiny pointed ; fingers of cheliped dark-tipped; merus of outer maxilliped not elongated, truncated anteriorly.

$d$. Carpus of cheliped with 2 spines, one above at distal end and a second below this on inner angle; hand roughened and armed above with 2 or more spines (sometimes inconspicuous).

e. Antero-lateral teeth acute, strongly produced, alternately large and small; carapace pubescent. $f$. Tenth antero-lateral tooth conspicuous, IIth present; dactyl of cheliped spiny.

C. gibbosulus

ff. Tenth antero-lateral tooth inconspicuous, I Ith not present; dactyl of cheliped not spiny. C. jordani

$e e$. Antero-lateral teeth broadly triangular, not strongly produced, subequal; carapace not pubescent.

C. amphioetus

$d d$. Carpus of cheliped with a single spine above at distal end; hand smooth or granulated, without spines.

e. Carapace widest at 8th antero-lateral tooth, IIth distinct; dark color on dactyls of cheliped reaching more than $1 / 2$ the length of outer margins; under parts spotted or blotched with reddish.

C. antennarius

$e e$. Carapace widest at 9 th antero-lateral tooth, Ioth inconspicuous; dark color on dactyls of chelipeds reaching less than $1 / 2$ the length of outer margins; under parts of uniform light color.

C. anthonyi

$a a$. Antero-lateral and postero-lateral margins not meeting at a distinct angle; carapace widest at 7 th or 8 th tooth; 12 or 13 teeth.

C. oregonensis 
Key to Species of the Genus Cancer Examined.

(Young of $20 \mathrm{~mm}$. and less in width.)

a. Front markedly produced, formed of 5 subequal teeth, of which the median is the most advanced; antero-lateral teeth never spiny pointed; carapace never pubescent. C. productus

aa. Front not markedly produced, formed of 5 unequal teeth, the outer teeth larger and more widely separated from the three median teeth than these from each other; antero-lateral teeth spinypointed; carapace generally pubescent.

b. Tenth antero-lateral tooth (counting that next the eye as one) prominent, usually spiny pointed.

c. Carpus of cheliped with 2 prominent spines (not counting that at hinge) one above at distal end, and the second below it at inner angle.

d. Tenth antero-lateral tooth projecting laterally beyond carapace as seen from above; carapace comparatively smooth.

C. gracilis

$d d$. Tenth antero-lateral tooth projecting dorsally, not reaching beyond outline of carapace as seen from above; carapace markedly areolated.

C. gibbosulus

$c c$. Carpus of cheliped with a prominent spine above at distal end; below this at inner angle an inconspicuous spine sometimes present. Under parts usually with red markings.

C. antennarius

$b b$. Tenth antero-lateral tooth absent or represented by a rudiment. c. Carapace finely pubescent, antero-lateral teeth alternately large and small; carpus of cheliped with 2 spines, one above at distal end and a second less conspicuous spine below this at inner angle.

C. jordani

$c c$. Carapace smooth or sparsely and coarsely pubescent, anterolateral teeth alternately large and small only in very young specimens ( $5 \mathrm{~mm}$. or less); carpus of cheliped with a spine above at distal end and only in very young a second minute spine below this at inner angle.

C. anthonyi 


\title{
Cancer productus Randall.
}

\author{
Plate VIII, figs. 20-24.
}

Cancer productus Randall, Journ. Acad. Nat. Sci. Phila., viii, 116, 1839.-Holmes, Occas. Papers Calif. Acad. Sci., vii, 47, 1900.-Kathbun, H. A. E., x, I75, 1904.

This species is represented by numerous specimens, as it is one of the most common of the large shore crabs of Monterey Bay. Age differences, as noted by various writers, are conspicuous. The most noteworthy are in the relative length and width of the carapace and the width of the front, and as the age differences in this species are in general similar to those of the genus and show of how little value are such specific characters as the proportion of the front to the total width of the carapace, a considerable series of measurements is given. The frontal and antero-lateral teeth in the adult are more sharply defined and have more acute tips than in the young, and on the other hand the crests on the hand of the young are more acute than those of the adult. Another age difference which I have not seen mentioned is that of the length of the external maxillipeds. In the adult they overlap the endostome to a marked degree, and this has been used as a family character. In the young, however, the maxillipeds are shorter and reach only to the endostome, as is the case with many of the Pilumnidæ-Xanthias, Cycloxanthops, and others.

The adult color of a "dark red above, below, a dirty white" or "yellowish white" is not invariable, though there are no striking differences; some adults show a light red above due to minute red spots, not so numerous as in the case of the darker color, on a yellowish ground. The longitudinal colored lines of the immature specimens as described by Holmes is not the invariable youthful coloration; various mottled patterns are also found and occasionally the red of the adult.

The chief sexual difference seemed to be the greater convexity of the female carapace, which is quite marked in large specimens.

All specimens listed in the following table, except as otherwise staterl, are from Pacific Grove.

The breadth of the carapace was measured at the eighth anterolateral tooth, the inter-orbital width was measured between the inner supra-orbital fissures; the convexity was the height of the center of the carapace above the tips of the eighth antero-lateral teeth, and this per cent is calculated on the basis of total width $=100$; all other per cents have the total length as IOO; owing to the difficulty of measurement, the convexity is less reliable than the other measurements. 
Table of Measurements of Cancer Productus.

\begin{tabular}{|c|c|c|c|c|c|c|c|c|c|c|}
\hline \multirow{3}{*}{ Sex } & \multicolumn{3}{|c|}{ Carapace } & \multirow{2}{*}{\multicolumn{2}{|c|}{$\begin{array}{l}\text { Interorbital } \\
\text { width }\end{array}$}} & \multirow{2}{*}{\multicolumn{2}{|c|}{$\begin{array}{l}\text { Width of } \\
\text { second } \\
\text { abdominal } \\
\text { segment }\end{array}$}} & \multirow{2}{*}{\multicolumn{2}{|c|}{ Convexity }} & \multirow{3}{*}{ Remarks } \\
\hline & \multirow{2}{*}{$\mid \frac{\text { Length }}{\mathrm{mm} .}$} & \multicolumn{2}{|c|}{ Breadth } & & & & & & & \\
\hline & & $\mathrm{mm}$. & $\%$ & $\mathrm{~mm}$. & $\%$ & $\mathrm{~mm}$. & $\%$ & $\mathrm{~mm}$. & $\%$ & \\
\hline immature & 4.0 & $4 \cdot 3$ & 108 & 2.4 & 60 & I.O & 25 & . & . . & color whitish \\
\hline “ & 4.0 & $4 \cdot 4$ & I 10 & 2.4 & 60 & I.O & 25 & . & . . & " \\
\hline " & $4 \cdot 3$ & $4 \cdot 5$ & 105 & 2.5 & $5^{8}$ & 1.0 & 24 & .. & .. & “ \\
\hline “ & $* 5.0$ & 5.8 & I 15 & 2.8 & 55 & 1.3 & 25 & .. & . & reddish \\
\hline “" & $5 \cdot 3$ & 6.5 & I 23 & 3.0 & 57 & I. 3 & 25 & .. & . & brown \\
\hline “" & $* 5.5$ & 6.3 & I I 4 & 2.8 & $5^{1}$ & I. 3 & 23 & . . & . & whitish \\
\hline " & $5 \cdot 6$ & 6.7 & I 20 & $3 \cdot \mathrm{I}$ & 55 & I. 6 & 29 & . & . & slate \\
\hline “ & $* 6.5$ & 8.0 & I 24 & $3 \cdot 3$ & $5^{\circ}$ & I. 5 & 24 & . & . & reddish \\
\hline “" & 6.6 & 8.3 & I 26 & $3 \cdot 5$ & 53 & I. 7 & 26 & . & . & light \\
\hline “ & 6.7 & 8.4 & I 25 & $3 \cdot 7$ & 55 & I.9 & 28 & . & . & longitudinal \\
\hline “ & $7 \cdot 9$ & 10.0 & I 26 & $4 \cdot 0$ & $5^{I}$ & 2.0 & 25 & .. & . & light \\
\hline “ & 9.0 & I 2.0 & I 33 & $4 \cdot 4$ & 49 & 2.3 & 26 & . & . & “ \\
\hline " & 9.0 & I 2.3 & I 37 & $4 \cdot 4$ & 49 & 2.3 & 26 & . & . & “" \\
\hline “" & 9. I & I 2.6 & I 39 & $4 \cdot 4$ & $4 \mathrm{~S}$ & 2.5 & 28 & . & . & white \\
\hline femiale & 17.0 & $24 \cdot 5$ & I 44 & $7 \cdot 5$ & 44 & $3 \cdot 5$ & 21 & 2.0 & 8 & light-striped \\
\hline “ & 23.0 & 34.0 & I 48 & 9.0 & 39 & $5 \cdot 0$ & 22 & 4.0 & I 2 & slate \\
\hline “" & 24.0 & 36.5 & I 52 & $9 \cdot 5$ & 40 & $5 \cdot 5$ & 2.3 & 4.0 & I I & light \\
\hline “" & 25.0 & 37.0 & I 48 & 10.0 & 40 & 6.0 & 24 & $3 \cdot 5$ & 9 & large red spot \\
\hline “ & 25.0 & 37.0 & I 48 & 10.0 & 40 & 6.0 & 24 & 4.0 & II & slate \\
\hline “" & 33.0 & .50 .0 & I $5^{2}$ & I 2.0 & 36 & 8.5 & 26 & $4 \cdot 5$ & 9 & red mottled \\
\hline “" & 37.0 & 56.0 & I 54 & I 3.5 & 36 & 9.5 & 26 & $5 \cdot 5$ & ro & reddish \\
\hline “ & 40.0 & 62.0 & I 55 & $I_{4} .0$ & 35 & 10.0 & 25 & 6.0 & Io & $\tan$ \\
\hline “ & 41.5 & 65.0 & I 57 & I $4 \cdot 5$ & 35 & 11.0 & 27 & 5.0 & I 2 & faintly striped \\
\hline “" & $54 \cdot 5$ & 86.5 & I 59 & I8.0 & 33 & 14.0 & 26 & . & .. & dark red \\
\hline 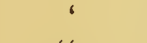 & 66.5 & 105.5 & I $5^{8}$ & 20.0 & 30 & 19.0 & 29 & $7 \cdot 5$ & 7 & " " \\
\hline “" & 78.5 & I 27.0 & 162 & $23 \cdot 5$ & 30 & $24 \cdot 5$ & $3 I$ & $15 \cdot 5$ & 20 & “” \\
\hline male & 20.0 & 28.5 & I 43 & 8.0 & 40 & 4.0 & 20 & 2.0 & 10 & \\
\hline " & 22.5 & 34.2 & I 53 & 9. I & 40 & 6.6 & 29 & . & . & slate with stripe \\
\hline " & 25.0 & 38.0 & I 52 & 10.0 & 40 & 6.0 & 25 & 4.0 & I I & faintly striped \\
\hline “ & 25.0 & 38.5 & I 54 & $9 \cdot 5$ & $3^{8}$ & 5.0 & 20 & 4.0 & IO & . \\
\hline$"$ & 26.5 & 40.5 & I 53 & I0. 5 & 40 & 6.0 & 23 & $3 \cdot 5$ & 9 & mottled \\
\hline " & $27 \cdot 5$ & 41.0 & I 50 & I I.O & 40 & 6.0 & 22 & 3.0 & 7 & faintly striped \\
\hline a & 29.0 & 44.0 & 152 & II.O & $3^{8}$ & 6.5 & 25 & 3.0 & 7 & striped \\
\hline “" & 29.0 & 44.0 & 152 & I I.O & $3^{8}$ & 6.5 & 25 & $3 \cdot 5$ & 8 & mottled, dark \\
\hline “ & 33.0 & 52.0 & I 58 & 12.5 & $3^{8}$ & $7 \cdot 5$ & 23 & 6.0 & I 2 & \\
\hline & $37 \cdot 5$ & $5^{8.0}$ & I 55 & 14.0 & 37 & 9.0 & 24 & $5 \cdot 5$ & 9 & dark red \\
\hline 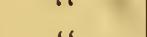 & $37 \cdot 5$ & 59.0 & I 57 & 14.0 & 37 & $9 \cdot 0$ & 24 & . & . & striped, light \\
\hline 6 & 66.0 & 108.0 & 164 & 21.0 & 32 & I6.0 & 24 & . & & dark red \\
\hline “" & $73 \cdot 5$ & 121.5 & I 65 & 22.0 & 30 & I 8.0 & 25 & $9 \cdot 5$ & 8 & “" \\
\hline 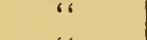 & 82.0 & 136.0 & I 66 & 25.0 & $3 I$ & 20.0 & 24 & 10.5 & 8 & “ \\
\hline "“ & 103.0 & 171.0 & I 66 & 30.0 & 29 & 25.0 & 24 & 20.0 & 12 & $“$ \\
\hline 6 & 103.0 & 173.5 & I 68 & 31.0 & 30 & 27.0 & 26 & 12.0 & 7 & " \\
\hline
\end{tabular}

* These three specimens are from Puget Sound. 


\title{
Cancer magister Dana.
}

\author{
Plate IX, fig. 25.
}

Cancer magister Dana, Proc. Acad. Nat. Sci. Phila., viii, 78, 1852.-Holmes, Occas. Papers Calif. Acad. Sci., vii, 50, 1900, and synonymy.-Rathbun, H. A. E., x, I77, 1904.

This species is common in the Monterey markets, but has not been obtained in any of the dredging done by the laboratory.

\section{Cancer gracilis Dana.}

\section{Plate IX, figs. 26-28.}

Cancer gracilis Dana, Proc. Acad. Nat. Sci. Phila., vi, 73, 1852.-Holmes, Occas. Papers Calif. Acad. Sci., vii, 52, 1900, and synonymy.-Rathbun, H. A. E., x, 177, 1904.

Cancer gracilis is represented by a considerable number of specimens, both young and adult, all obtained by dredging, though in Puget Sound it is an abundant shore crab. On several occasions the young of this species has been found in considerable numbers clinging to the subumbrella of various medusæ. These have all been of small size -5 to ro mm.-but it was not until the summer of 1908 that younger stages were found. On one occasion a number of medusæ were collected and in examining these many very young crabs were obtained and a smaller number of megalops. Some of these were kept alive until the molt to the young crab stage took place, so that there can be little doubt that the specimens were really the megalops of gracilis. Later megalops were obtained from other species of medusæ, and crabs of a slightly larger size than those found on the jelly-fish were dredged in considerable numbers; it would appear, therefore, that in the case of gracilis, at least a considerable number of individuals pass that portion of their life history from the end of the free-swimming stage, probably early megalops, until reaching a size of 15 to $20 \mathrm{~mm}$. clinging to medusæ, after which they drop to the bottom and live in the manner of the adult. I have found no other species than gracilis on medusæ though Miss Rathbun reports one specimen of jordani from the same situation. It would be interesting to know if this form of life history were universal with gracilis and if it were common in any other species.

Color in life olive overlaid with minute reddish brown spots, which are more numerous on the teeth of the antero-lateral margin and on the 
front and give to the whole a brownish tinge; edges of teeth, under parts and greater portion of legs, yellowish. There is little variation in color among individuals and but small difference between fresh and alcoholic specimens.

\section{Cancer gibbosulus (de Haan).}

Plate X, fig. 29.

Corystes (Trichocera) gibbosula de Haan, Fauna Japon., 45, pl. ii, fig. 4, pl. xiii, fig. 3,1835 .

Tricocarcinus gibbosulus Miers, Proc. Zool. Soc. London, 34, 1879.

Cancer gibbosulus Rathbun, Proc. U. S. Nat. Mus., xxi, 58I, 1898.-Rathbun, H. A.

E., $x, 176,1904$.

This species is represented in the collection by several specimens, the largest measuring 35.5 by $25.5 \mathrm{~mm}$., all obtained by dredging at moderate depths-io to 20 fathoms.

As no figures or detailed descriptions are easily available, the large male whose measurements are given above is figured and the following description given.

Carapace markedly areolated, the most conspicuous depressions running back from the outer angle of the eye nearly to the posterior margin of the carapace and enclosing between them the gastric, cardiac, and intestinal regions. Gastric region divided by a groove beginning at the median tooth of front, passing back and dividing like an inverted $\mathrm{Y}$, the arms of which form the anterior boundary of the cardiac region. The lateral margins of the cardiac region converge posteriorly; from the anterior end where they meet the arms of the $\mathrm{Y}$, a pair of rather shallow grooves run to the antero-lateral margin of the carapace, ending between the fifth and sixth teeth. Carapace sparsely pubescent, hairs rather conspictous and harsh. Antero-lateral margin, including outer angle of orbit, with 9 strongly produced and forward curving teeth, all except first two tipped with spines. Behind these on postero-lateral margin a well marked tenth tooth directed upward and not laterally and a distinct spine representing the eleventh. A conspicuous raised ridge along the posterolateral border and another across the posterior margin. Front with 5 acute teeth-not counting the supra-orbital-the three median of whicis are the smaller and are separated from the tooth at inner angle of eye by a distance rather greater than that occupied by the three. Supra-orbital tooth acute, margin of orbit prominent, eyes and stalks normal. Antennæ large, stout, and conspicuously hairy, about equaling width of front ; outer 
angle of basal joint produced, acute and plainly visible from above, reaching about as far forward as median tooth of front.

Merus of maxillipeds abruptly truncated, inner angle slightly produced, inner margin with a conspicuous tooth below the articulation of palp. Exognath stout, reaching to end of merus.

Chelipeds hairy, carpus with a conspicuous spine near hinge, another inside of this terminating a slight ridge and reaching well forward, and a third below this on the inner side. This latter tooth is more conspicuous than in any other species with the possible exception of gracilis. Upper surface of carpus with a few reddish spines, upper surface of hand with two rows of three to five spines, outer surface with 5 costæ marked with hair and small spines, upper margin of dactyl spiny. Fingers meeting along most of their length, armed with conspicuous teeth. Ambulatory legs hairy, dactyls slightly longer than the propodi, straight, tipped with nearly straight corneus spines.

Abdomen of 7 joints, regularly tapering from the third to the tip; terminal joint long and slender, reaching nearly to the anterior border of the coxæ of the chelipeds.

Color whitish marked with irregular but symmetrically disposed reddish blotches, tips of fingers of chelipeds black, ambulatory legs light banded with red.

Since writing the above description another and still larger specimen of this species, also dredged from about Io fathoms in Monterey Bay, has come into my hands. As it differs somewhat from the preceding it seemed well to add the following points. Although the proportion of width to length in the carapace is almost exactly that of the one described ( 46 by $32.5 \mathrm{~mm}$.), it appears wider, as the lateral teeth are much shorter. The areolation is distinct but rather less deep than in the former case, the pubescence is similar though a trifle more dense, and there is a tendency towards tufts of setæ and granules on the prominences of the carapace which is barely indicated in the other. The antero-lateral teeth are similar but less acute and projecting and with more pronounced secondary denticulations. The teeth of the front are less acute and prominent, especially the supra-orbital. Chelipeds similar but even more markedly spiny. General color reddish, due to light red marblings on a whitish ground.

As pointed out before, the young of this species closely resemble the young of $C$. gracilis. The large specimen at hand shows an almost equally striking resemblance to the hairy form of $C$. antcnnarius noted under that species, lending some color to the supposition that that form may repre- 
sent a hybrid. The specimen at hand and the hairy extreme of antennarius figured in plate XI, fig. 32, resemble each other very closely in the areolation and pubescence of the carapace and in the appearance of the antero-lateral teeth, differing in the two former cliaracters markedly from the typical antennarius. The frontal regions are similar. The greatest differences lie in the chelipeds and in the dactyls of the ambulatory legs. Although the hand and carpus of this specimen of antennarius is much more spiny than in the typical form, and thus approaches gibbosulus, yet it is less spiny than in the specimen of gibbosulus at hand, particularly in the case of the two at the inner angle of the carpus, which are much less prominent and acute. The dactyls of the ambulatory legs in the specimen of antennarius are of the typical form for that species, and are shorter, stouter and more curved than are those of gibbosulus. In the specimen of antennarius the dark color of the dactyl of the cheliped is less extensive than in gibbosulus. The characteristic red spotting of the under surface of antennarius is also absent in the specimen of gibbosulus.

Cancer jordani Rathbun.

Plate X, fig. 30 .

Cancer jordani Rathbun, American Nat., xxxiv, 133, 1900.-Rathbun, H. A. E., x, I76, 1904 .

This species is represented by over 25 specimens, mostly collected along shore, though a few were dredged. They range in size from 5 to $25 \mathrm{~mm}$. in length, and as the largest specimen recorded by Miss Rathbun is $20 \mathrm{~mm}$. in length, a figure is given of the largest individual and a description partly in the words of Miss Rathbun (H. A. E., x, I76). The series includes two egg-bearing females, the only ones which I have seen; their size, as seen from the table of measurements, is below that of many of the other specimens, both male and female.

Carapace more than one and one-fourth times as wide as long. The proportion in the large male here described is $I .33$ to $I$, but this varies with age: see table of measurements. (The statement "Length of carapace one and a fourth times width" is obviously a misprint, as the length is later given as 15.5 and the width as $19.5 \mathrm{~mm}$.) "Surface hairy and "covered with small crowded scabrous granules. Regions indicated by "narrow and shallow depressions. Teeth of front and lateral border not "thickened as in antennarius; inner orbital tooth very slightly produced; 
"margin of upper orbital tooth almost transverse, scarcely dentiform. "Lateral teeth separated to their bases, tips spiniform and curved for"ward; second, fourth, sixth, and eighth smaller than the others (the "outer orbital tooth reckoned as the first); ninth tooth scarcely more "prominent than eighth. No postero-lateral tooth." The alternation in size of the antero-lateral teeth varies with age, being very noticcable in the small specimens and hardly evident in this the largest of the series. It also appears, as stated elsewhere, in the young of other species. The tenth (postero-lateral) tooth is indicated in the present specimen, and less conspicuously in other younger ones, by a slight gap in the small spines marking the raised postero-lateral margin. "Basal antennal tooth and that of adjoining margin acute," but less produced than in gibbosulus. "Movable part of antennæ [nearly] half as long as carapace." In many of the other specimens the antennæ fall considerably short of this length. "The outer maxillipeds overlap considerably the basal joint of the antennæ; merus longer than wide;" obliquely truncated, the inrer angle the more advanced, corners rounded. "The palms of the chelipeds have two superior and five external carinæ fringed with hair." The superior carinæ are marked with several small spines besides the hairs. " $O_{11}$ the prehensile edges of the fingers the dark color runs from the proximal end of the fingers nearly to the tips, but on the outer edges the dark color begins near the middle of the fingers." In the key given by Miss Rathbun in the American Naturalist, jordani falls under the division, "Color on the fingers extending from the tip not more than half the length of the fingers." In the specimen before me and in most of the collection the color extends from the tip of the dactyl distinctly more than half way to its base on the outer edge.

The measurements of this the largest of the collection and of a series of smaller specimens are here given:

\begin{tabular}{|c|c|c|c|c|}
\hline SEX & LENGTII & WIDTH IN & $\begin{array}{l}\text { TER-ORBITAL } \\
\text { WIDTH }\end{array}$ & $\begin{array}{l}\text { ANTENNAL } \\
\text { LENGTH }\end{array}$ \\
\hline male & $\begin{array}{l}25.4 \mathrm{~mm} . \\
22.0\end{array}$ & $\begin{array}{l}33.4 \mathrm{~mm} . \\
28.5\end{array}$ & $\begin{array}{l}\text { IO. } 3 \mathrm{~mm} . \\
9.0\end{array}$ & $\begin{array}{l}\text { I3.0 mm. } \\
8.0\end{array}$ \\
\hline$"$ & 19.0 & 24.6 & 8.0 & 8.0 \\
\hline$"$ & 14.0 & 17.0 & 6.0 & 6.5 \\
\hline female & I 8.5 & $23 \cdot 7$ & 8.0 & 8.0 \\
\hline & I6.0 & 20.0 & $7 \cdot 3$ & $7 \cdot 5$ \\
\hline$"$ & II. 2 & $\mathrm{I} 4 \cdot 3$ & 5.0 & 5.0 (carrying eggs) \\
\hline$"$ & 10.2 & I2. 5 & 5.0 & 5.0 \\
\hline$"$ & IO. 5 & 12.5 & 5.0 & 5.0 (carrying eggs) \\
\hline
\end{tabular}




\section{(Cancer amphioetus Rathbun.)}

Trichocarcinus dentatus Miers, Proc. Zool. Soc. London, 34, 1879.

Cancer amphioctus Rathbun, Proc. U. S. Nat. Mus., xxi, 582, 1898.-Rathbun, H. A.

E., $x, 175,1904$, and synonymy.

No specimens of this species are in the University collection. Its range on the Pacific coast-Magdalena Bay to San Diego Bay-and its occurrence in Japan, make it at least possible that it will be found farther north, as has proved the case with gibbosulus, and I have included it in the keys for completeness.

Cancer antennarius Stimpson.

Plate X, fig. 3I. Plate XI, fig. 32 .

Cancer antennarius Stimpson, Proc. Calif. Acad. Sci., I, 88, I856.-Holmes, Occas. Papers Calif. Acad. Sci., vii, 49, 1900, and synonymy.-Rathbun, H. A. E., x, 176, 1904.

This is one of the largest and most common crabs along shore at Pacific Grove and is represented by numerous specimens ranging in width from less than $10 \mathrm{~mm}$. to $120 \mathrm{~mm}$.

There is considerable variation in this species and apparently a tendency toward two types, the extremes of which might readily be taken as separate species. By far the greater number-which I would consider typical antennarius - have a smooth carapace devoid of hair except in the very young- $5 \mathrm{~mm}$. and less in width-where there are a few coarse hairs. A small number show a tendency toward hairiness and roughness of the hand, the extreme type of which, represented by a young female measuring 46 by $50 \mathrm{~mm}$., is shown in figure $32, \mathrm{Pl}$. XI. In this the whole carapace is densely pubescent (typical specimens of half the size show a perfectly bare carapace) and on the summits of the areolations, which are more marked than in the typical form, there are bunches of larger and stouter hairs. The granulations on these elevations are coarser than on the rest of the carapace and in some cases pass into small spines. The antero-lateral teeth do not differ markedly from the typical form except in being more thickened and in having the teeth spiny pointed. The frontal teeth are more acute and thicker than is common in antennarius, especially those lying on either side of the median tooth. The tips of the basal joint and of the adjoining tooth on the lower orbital margin are more acute than in typical antennarius of the same size. 
The chelipeds and ambulatory legs are pubescent, as is the case with the carapace. The carpus of the chelipeds is marked with several costæ bearing low spines and rows of hairs; these costæ are generally indicated in the typical form by a line of slightly coarser granulations. There is an acute tubercle above the hinge, a strong spine at the inner angle and a well marked spine below this. These spines are present in some typical antennarius of the same size, but the lower spine is more generally lacking and never of as great size. The hand is marked with two superior and five external carinæ, all formed of rows of hairs and spines, the spines in the upper carinæ being much longer and more pronounced. In typical antennarius of the same size these carinæ are more or less well marked by rows of granulations.

This specimen is, as I have said, the extreme of divergence from the typical form; other smaller individuals show the same pubescence, some have the same extreme type of areolation, notably a larger female from San Diego, the only one not from Monterey Bay here considered, many young show roughness of the hand, but no other specimen combines as many of these characters.

The total of these variations from the typical form of antennarius might merit specific distinction were it not for certain other facts. All specimens in which $I$ have noticed these characters in any marked degree are immature females. Though they differ from typical forms of the same size, and therefore presumably of similar age, yet certain of the characters, chiefly the roughness of the hand and the pubescence of the carapace, vary with age in the typical form, being more apparent in the young, so that these differences though apparently much greater than those due to age, cannot be said to be of a dissimilar kind. Again, in the typical adult. the female has a more convex and deeply areolated carapace than the male, which gives rise to a suspicion that the difference in this character may be, in part, sexual.

Miss Rathbun has informed me that she has examined very hairy specimens of about the size described-40 and $50 \mathrm{~mm}$.- from La Jolla and San Diego which she considered as a variety of antennarius. Sufficient material may establish this variety, but the collection at hand does not seem to warrant it.

The color of live specimens is fairly uniform and undergoes little change in alcohol. The general shade is a dark red usually more or less mottled with a lighter, more yellowish tinge; the under parts are yellowish white spotted with red, a coloration not found in any other species of Cancer examined. 


\section{(Cancer anthonyi Rathbun.)}

Plate XI, fig. 33 .

Cancer anthonyi Rathbun, Proc. Biol. Soc. Wash., xi, II I, I897.-Rathbun, Am. Nat. xxxiv, 134, 1900.-Rathbun, H. A. E., x, 176, 1904.

I have examined a series of four specimens from San Diego. The species is not recorded north of Long Beach, Cal., and I have included it merely for completeness.

\section{Cancer oregonensis (Dana).}

Plate XI, fig. 34 .

Trichocera oregonensis Dana, Proc. Acad. Nat. Sci. Phila., vi, 86, 1852.-Dana, Crus.

U. S. Exp. Exped., I, 299, 1852.

Trichocarcinus oregonensis Holmes, Occas. Papers Calif. Acad. Sci., vii, 54, Igoo. Trichocarcinus walkeri Holmes, op. cit. 53.

Cancer oregonensis Rathbun, H. A. E., x, 178, I904, and synonymy.

"Aleutian Islands to Lower California" Holmes. I have examined specimens of this species, but none which I know to have come from Monterey Bay.

\section{Family PORTUNIDÆ.}

\section{Genus PORTUNUS Fabricius.}

Portunus Fabricius, Entom. Sys. Suppl., 325, I798.

Lupa Leach, Edin. Encyc., vii, 390, 1814.

Lupania Rafinesque, Amer. Monthly Mag., iii, 272, Aug. 1818.

Neptunus de Haan, Fauna Japon., 3 and 7,1833 (Type-Portunus pelagicus(Linn.)).

\section{Portunus xantusii (Stimpson).}

Plate XII, fig. 35 .

Achclous xantusii Stimpson, Ann. N. Y. Lyc. Nat. His., vii, 222, I86o.

Portunus xantusii Holmes, Occas. Papers Calif. Acad. Sci., vii, 71,1900 and synonymy.-Rathbun, H. A. E., x, 179, 1904.

"Except for a single specimen taken by the Albatross in Puget Sound, this species is not known north of San Pedro, California" (Rathbun). I have seen no specimen from Monterey Bay. 


\title{
Family PILUMNIDÆ.
}

\section{Key to Genera of the Family Pilumnide.}

a. General shape of carapace transversely oval, division between anterolateral and postero-lateral margins not sharp, latter curved; front not markedly deflexed.

Cycloxanthops

$a a$. General shape of carapace not oval, antero-lateral and postero-lateral margins meeting at an angle, latter nearly straight; front much deflexed.

$b$. Front divided by a closed fissure.

$b b$. Front divided by an open rounded notch.

\section{Genus CYCLOXANTHOPS Rathbun.}

Cycloxanthus A. Milne Edwards, Ann. Sci. Nat. (4), xx, 278, I863.

Cycloxanthops Rathbun, Proc. Biol. Soc. Washington, xi, 164, I897 (Type-Cycloxanthops sexdecimdentatus (Edwards \& Lucas)).

\section{Cycloxanthops novemdentatus (Lockington).}

\author{
Plate XII, fig. 36.
}

Xanthodes? novem-dentatus Lockington, Proc. Calif. Acad. Sci., vii, 32, 1877.

Cycloxanthops novem-dentatus Holmes, Occas. Papers Calif. Acad. Sci., vii, 56, 1900. Cycloxanthops novemdentatus Rathbun, H. A. E., x, I80, 1904.

Represented in the collection by several specimens one of which was obtained by W. F. Allen. The general color in life is a dull reddish brown showing traces of purple at the posterior part of the carapace and still more strongly on the ambulatory legs and below, thus somewhat resembling Xanthias taylori; fingers of chelipeds black with teeth along inner margins white. One young specimen shows the tendency to white markings so common in the young of Lophopanopeus heathii.

This species has not previously been reported north of San Pedro.

\section{Genus LOPHOPANOPEUS Rathbun.}

Lophopanopeus Rathbun, Bull. Lab. Nat. Hist. State Univ. Iowa, 272, I898 (TypeLophopanopeus bcllus (Stimpson)). 
The following key to the species of this genus is taken from Miss Rathbun-Am. Nat. xxxiv, I36.

Key to species.

a. Hands smooth, without lobes or teeth on upper margin.

L. bellus

aa. Hands with one or more lobes or teeth on upper margin.

$b$. Carpus of chelipeds smooth or nearly so.

L. heathii

$b b$. Carpus of chelipeds very rough.

c. Carpus of chelipeds covered with reticulating ridges enclosing pits of irregular shape.

L. leucomanus

cc. Carpus of chelipeds covered with tubercles. L. diegensis

\section{Lophopanopeus bellus (Stimpson).}

Plate XII, fig. 37 .

Xantho bella Stimpson, Ann. Lyc. Nat. His. N. Y., vii, 204, pl. v, fig. 2, I860.

Lophoxanthops bellus Holmes, Occas. Papers Calif. Acad. Sci., vii, 60, 1900, and synonymy.

Lophopanopeus bellus Rathbun, H. A. E., x, I80, 1904, and synonymy.

Lophopanopeus bcllus is recorded from Monterey Bay, but it is with some hesitation that I place here some of the specimens which I have examined. In size, proportions of carapace and ornamentation of hand they correspond very closely with Miss Rathbun's description, but the carpus is exactly that given for L. lockingtoni; the granulated ridge at the distal margin and the sulcus behind this being the most obvious difference between these specimens and the more numerous $L$. heathii.

The color in life of this, as of Lophopanopeus heathii, is very variable, more so than any other crab found in the bay. Some specimens are almost pure white, while others show various irregular patterns of bluish and dark red or are wholly of the latter color.

\section{Lophopanopeus heathii (Rathbun).}

Plate XII, fig. 38 .

Lophopanopcus heathii Rathbun, H. A. E., x, I82, I904, and synonymy.

This is by far the most common species of this genus in Monterey Bay, and is represented in the collection by numerous specimens, all of which agree in having a smooth carpus. The color as before stated is very variable. 


\section{Lophopanopeus leucomanus (Lockington).}

Lophopanopeus leucomanus Rathbun, H. A. E., x, 182, 1904, and synonymy.

Though recorded from the bay, I am unable to find among a large number of specimens of this genus any corresponding to the description of leucomanus. A specimen from San Diego has been examined.

\section{Lophopanopeus diegensis Rathbun.}

Plate XII, fig. 39 .

Lophopanopeus diegensis Rathbun, Am. Nat., xxxiv, I37, I900.-Rathbun, H. A. E., $x, 184,1904$.

There are ${ }_{5} 5$ specimens of this species in the collection all dredged from moderate depths, Io to I 5 fathoms. Many of the series, including some of the smallest, are egg-bearing females, indicating that the adult size is much less than that of $L$. heathii. All agree well with Miss Rathbun's description and figure though the carpal crests of the ambulatory legs are in some cases longer and more acute than represented. Color in life, dull brown or blackish occasionally tinged with red, but never conspicuously marked as in L. heathii.

This species has not been previously reported from north of San Diego and off Pt. Conception.

\section{Genus XANTHIAS Rathbun.}

Xanthodes Dana, Proc. Acad. Nat. Sci. Phila., vi, 75, I852 (Name preoccupied). Xanthias Rathbun, Proc. Biol. Soc. Washington, xi, 165, 1897 (Type-Xanthias granoso-manus (Dana)).

\section{Xanthias taylori (Stimpson).}

Plate XIII, fig. 40.

Xanthodes taylori Stimpson, Ann. Lyc. Nat. Hist. N. Y., vii, 208, pl. 3, fig. 3, 1859. Xanthias taylori Holmes, Occas. Papers Calif. Acad. Sci., vii, 65, 1900, and synonymy.

-Rathbun, H. A. E., x, 185, 1904.

Quite common and represented in the collection by numerous specimens. Color in life a uniform dark red, lighter below, fingers black. In all the specimens there is a tendency towards fusion of the tubercles on the carpus of the cheliped so that a ridge is formed along the distal end of the joint, while in some specimens from San Diego these tubercles are distinct and more prominent. 


\section{Family PINNOTHERID曆.}

The material in this family is not so extensive or satisfactory as that in the case of the other families here treated, and for that reason no extended treatment is attempted. The following key to genera is in part adapted from Miss Rathbun (Am. Nat., vol. xxxiv, p. 588). No specimens of either Scleroplax or Cryptophrys were available for comparison; the key moreover is not intended to apply to other than coast forms.

\section{Key to the Genera of Pinnotheride Found in Monterey Bay.}

$a$. Ischium of outer maxilliped rudimentary.

$b$. Palp of outer maxilliped with three joints.

c. Carapace with longitudinal sulci behind the orbits enclosing the median area (legs slender, dactyls of similar length).

$c c$. Carapace without longitudinal sulci.

Raphonotus

$d$. Legs subequal, dactyls of last pair markedly longer than those of preceding pair; carapace suborbicular.

Pinnotheres

$d d$. Legs subequal or markedly unequal, dactyls of last pair always shorter than those of preceding pair; carapace markedly wider than long.

$e$. Third ambulatory leg markedly longer than others.

Pinnixa

ee. Third ambulatory leg not markedly longer than others. Scleroplax

$b b$. Palp of outer maxilliped with two joints.

Cryptophrys

$a a$. Ischium and merus of outer maxilliped separate or incompletely fused.

(Carapace suborbicular, convex, hard; legs stout.) Opisthopus

\section{Genus PINNOTHERES Latreille.}

Pinnotheres Latreille, Hist. Nat. Crust., iii, 25, 1802.

\section{Pinnotheres nudus Holmes.}

Pinnotheres nudus Holmes, Proc. Calif. Acad. Sci., 2d ser. iv, 563, pl. xx, fig. I-5, I895.-Holmes, Occas. Papers Calif. Acad. Sci., vii, 86, 1900.-Rathbun, H. A. E., $x, 185,1904$. 
A single female is in the University collection probably from Monterey Bay, from which locality this species is alone recorded.

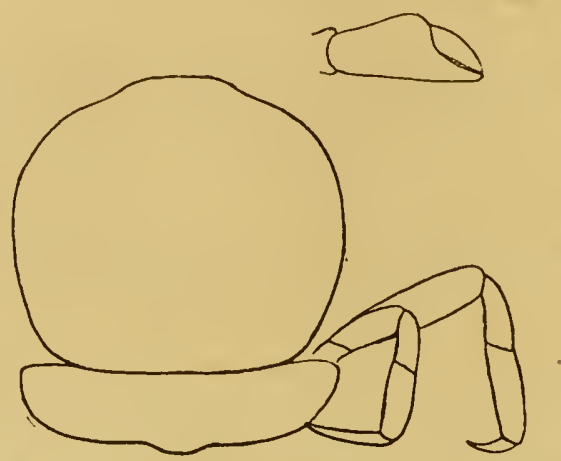

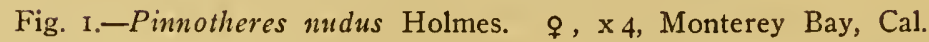

\section{Genus RAPHONOTUS Rathbun.}

Fabia Dana, Proc. Acad. Nat. Sci. Phila., 253, I85I.

Raphonotus Rathbun, Proc. Biol. Soc. Washington, xi, 166, 1897 (Type-Raphonotus subquadratus (Dana)).

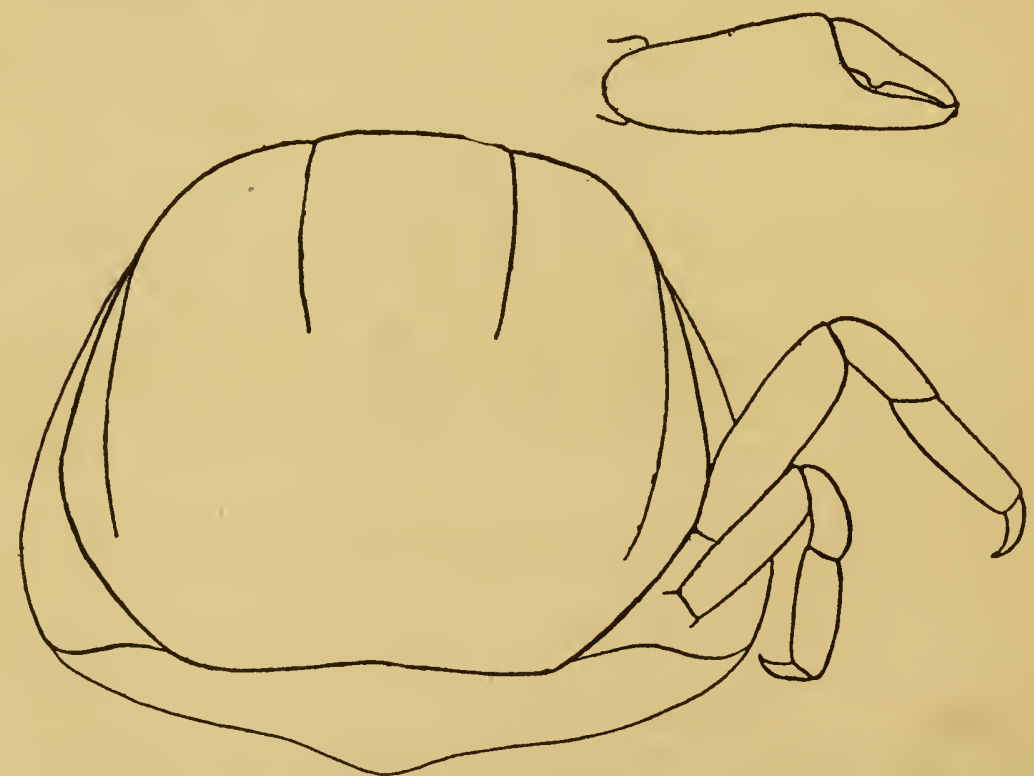

Fig. 2.-Raphonotus subquadratus (Dana). $\quad$, x $3^{1 / 2}$, Monterey Bay, Cal. 


\section{Raphonotus subquadratus (Dana).}

Fabia subquadratus Dana, Proc. Acad. Nat. Sci. Phila., 253, 1851.-Holmes, Occas.

Papers Calif. Acad. Sci., vii, 87, 1900, and synonymy (part).

Raphonotus subquadratus Rathbun, $\mathrm{H}$. Á. E., x, I86, 1904.

Numerous specimens of Raphonotus from Monterey Bay agree with Miss Rathbun's description of the portion retained as typical subquadratus, in distinction to $R$. lowei, in having a distally widened hand with two rows of hair on the lower margin although they do not all show pubescence of the frontal region. The females are very common in the mantle cavity of the mussel (Mytilus edulis.)-Miss Rathbun reports it also from folds of Lucapina crenulata-but I have seen no males.

\section{Genus PINNIXA White.}

Pinnixa White, Ann. Mag. Nat. Hist., xviii, 177, 1846 (Type-Pinnixa cylindrica Say).

The genus Pinnixa is well represented on the Pacific Coast but the material at hand is scanty. The following key to the species-taken in part from Miss Rathbun and Holmes-is not intended to apply to extralimital forms. I have examined all of the six species.

\section{Key to Species of Pinnixa Found in Monterey Bay.}

a. Dactyl of third pair of ambulatory legs straight.

$b$. Carapace about $I \frac{1}{2}$ times as wide as long.

P. faba

$b b$. Carapace twice or more than twice as wide as long.

c. Propodus of third pair of ambulatory legs largest at distal end, markedly wider than base of dactyl; pollux of cheliped not markedly shorter than dactyl and not bent downward.

P. tubicola

$c c$. Propodus of third pair of ambulatory legs largest near the proximal end, tapering to base of dactyl; pollux of cheliped shorter than dactyl and bent downward at an angle to the palm.

d. Carapace about twice as wide as long, areolations well marked.

$P$. occidentalis

$d d$. Carapace rather more than twice as wide as long, areolations less prominent.

$P$. californiensis 
aa. Dactyl of third pair of ambulatory legs distinctly curved.

$b$. Carapace considerably more than twice as wide as long; third ambulatory leg enormously developed, the distal end of the merus not being reached by dactyl of fourth. P. longipes

bb. Carapace twice or less than twice as wide as long; third ambulatory leg not enormously developed, the distal end of the merus being much over-reached by dactyl of fourth.

$P$. littoralis .

\section{(Pinnixa occidentalis Rathbun.)}

Pinnixa occidentalis Rathbun, Proc. U. S. Nat. Mus., xvi, 248, 1893.-Holmes, Occas. Papers Calif. Acad. Sci., vii, 89, 1900.-Rathbun, H. A. E., x, 187, 1904.

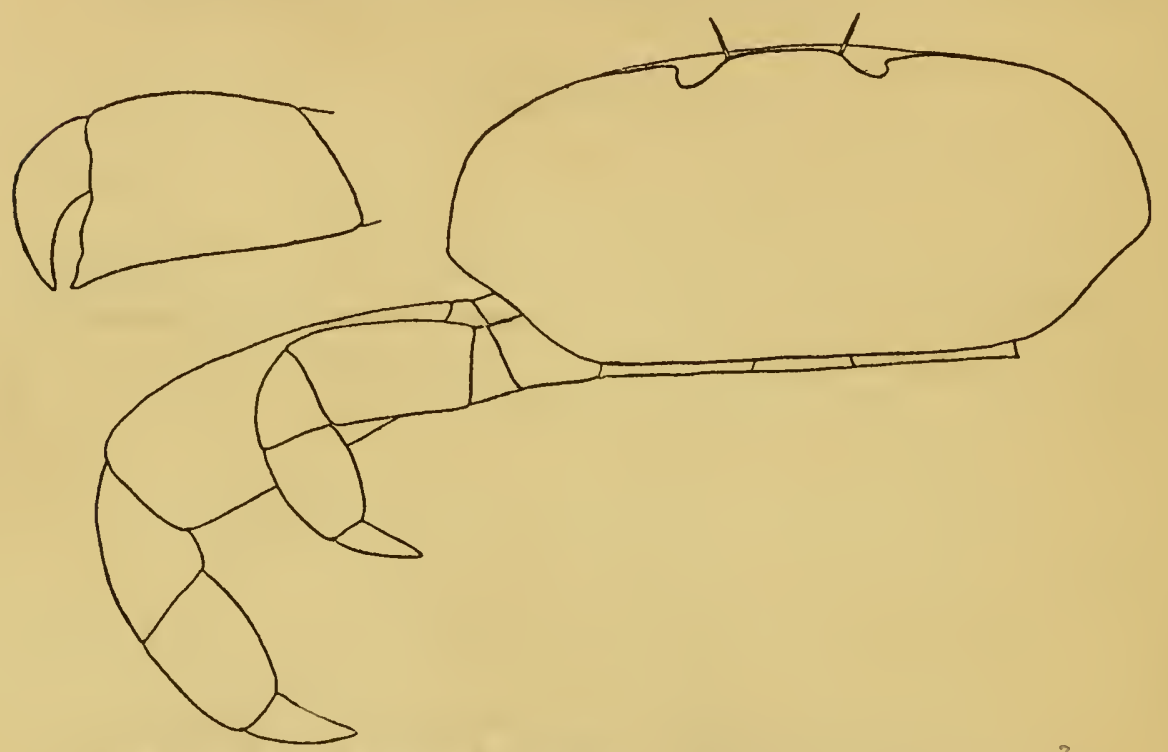

Fig. 3.-Pinnixa occidentalis Rathbun. ô, x 5, Monterey Bay, Cal. ?

There is in the University collection a bottle containing several specimens of this together with two females of the following species, apparently from Monterey Bay, but as the southern limit of this species as given by Holmes is Humboldt County, I feel some hesitation in adding it to the present list.

\section{Pinnixa californiensis Rathbun.}

Pinnixa californiensis Rathbun, Proc. U. S. Nat. Mus., xvi, 249, 1893.-Holmes, Occas. Papers Calif. Acad. Sci., vii, 90, 1900.-Rathbun, H. A. E., x, 187, 1904. 
There is beside the two females referred to above, one young female found free on the beach at Pacific Grove which I take to belong to this species as they differ from the preceding in having a smoother and slightly wider carapace. Its range is given as from off $\mathrm{Pt}$. Ano Nuevo to Lower California.

\section{Pinnixa tubicola Holmes.}

Pinnixa tubicola Holmes,Proc. Calif. Acad. Sci., 2d ser., iv, 569, pl. xx, figs. 17-18, I895; Occas. Papers Calif. Acad. Sci., vii, 9I, 1900.-Rathbun, H. A. E., x, 187, I904.

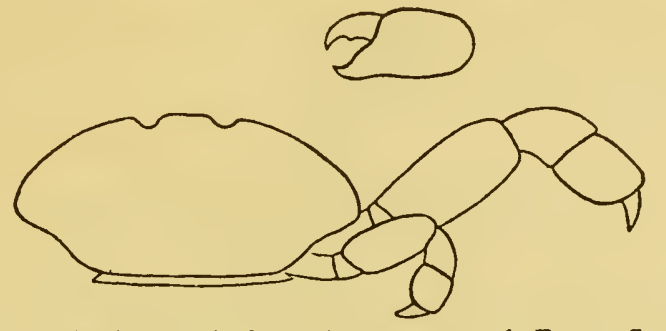

Fig. 4.-Pinnixa tubicola Holmes. ô, x6, Puget Sound.

A single female dredged from shallow water-1o to I5 fathoms- is in the collection.

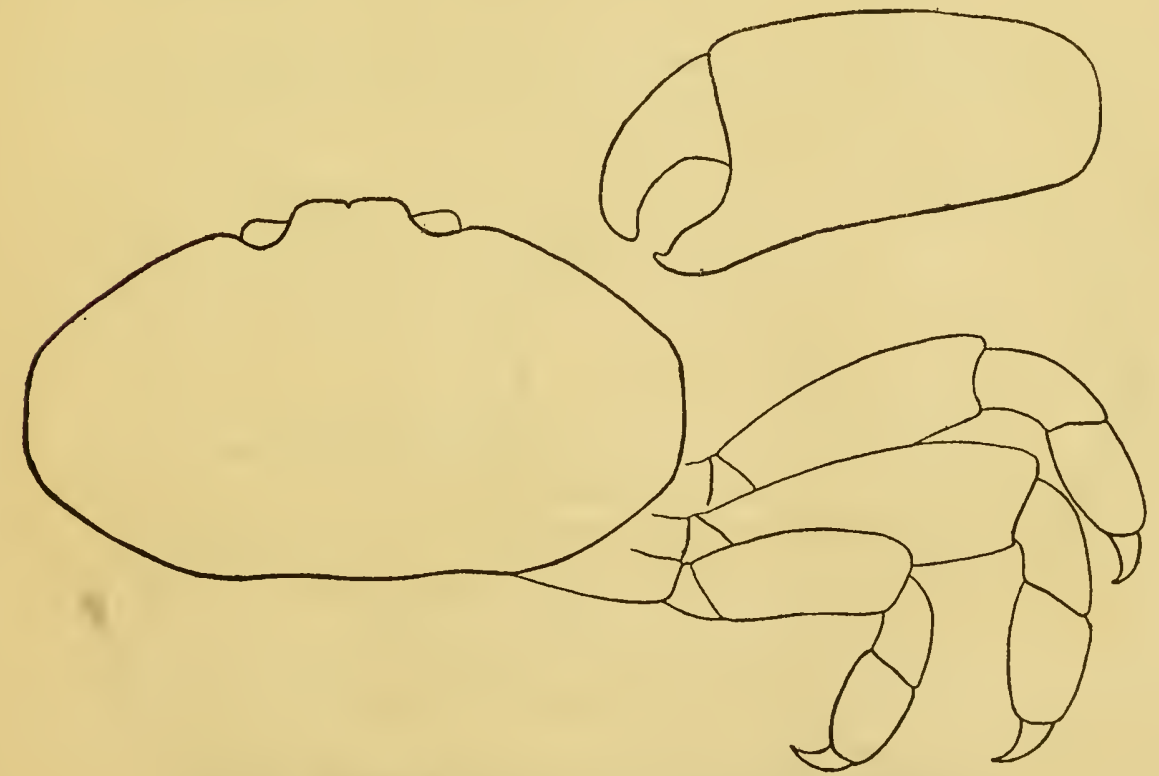

Fig. 5.-Pinnixa littoralis Holmes. $\hat{o}, \mathrm{x} 7$, Puget Sound. 


\section{Pinnixa littoralis Holmes.}

Pinnixa littoralis Holmes, Proc. Calif. Acad. Sci., 2d ser., iv, 571, pl. xx, figs. 14-16, I895; Occas. Papers Calif. Acad. Sci., vii, 91, I900.-Rathbun, H. A. E., x, $187,1904$.

"Bodega Bay to San Diego" (Rathbun). I have seen no specimen of this species from Monterey though examples are in the collection from Puget Sound.

\section{Pinnixa longipes (Lockington).}

Tubicola longipes Lockington, Proc. Calif. Acad. Sci., vii, 55, 1877.

Pinnixa longipes Holmes, Occas. Papers Calif. Acad. Sci., vii, 92, 1900, and synonymy.-Rathbun, H. A. E., x, 187, 1904.

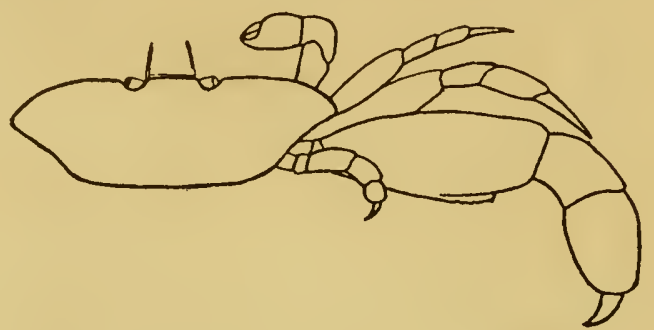

Fig. 6.-Pinnixa longipes (Lock.). From Holmes.

"Tomales Bay to San Pedro" (Rathbun). Two young specimens of this species are in the collection. $\mathrm{N}$.

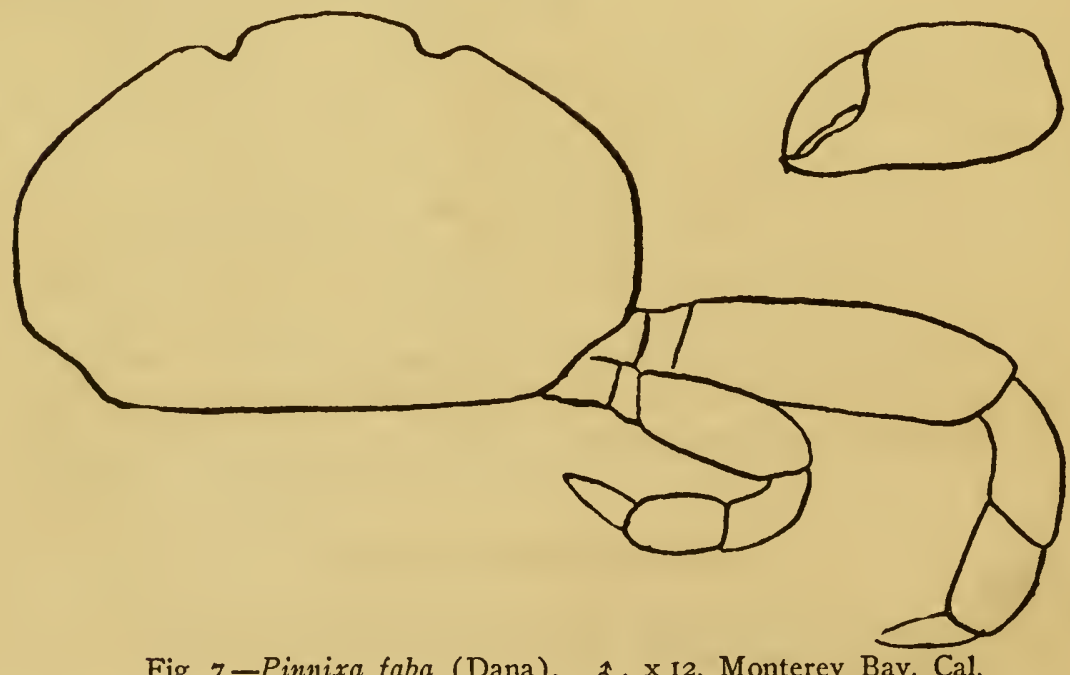

Fig. 7.-Pinnixa faba (Dana). $\hat{\jmath}, \mathrm{x} \mathbf{1} 2$, Monterey Bay, Cal. 


\section{Pinnixa faba (Dana).}

Pinnotheres faba Dana, Proc. Acad. Nat. Sci. Phila., 248, 1851.

Pinnixa faba Holmes, Occas. Papers Calif. Acad. Sci., vii, 93, 1900, and synonymy.Rathbun, H. A. E., x, 188, 1904.

There is one male of this species in the collection obtained free in shallow water -5 fathoms-in Monterey Bay.

\section{Genus SCLEROPLAX Rathbun.}

Scleroplax Rathbun, Proc. U. S. Nat. Mus., xvi, 250, 1893 (Type-Scleroplax granulata Rathbun).

\section{Scleroplax granulata Rathbun.}

Scleroplax granulata Rathbun, Proc. U. S. Nat. Mus., xvi, 25I, 1893.

Pinnixa (Scleroplax) granulata Holmes, Occas. Papers Calif. Acad. Sci., vii, 94, 1900.

Scleroplax granulata Rathbun, H. A. E., x, 188, 1904.

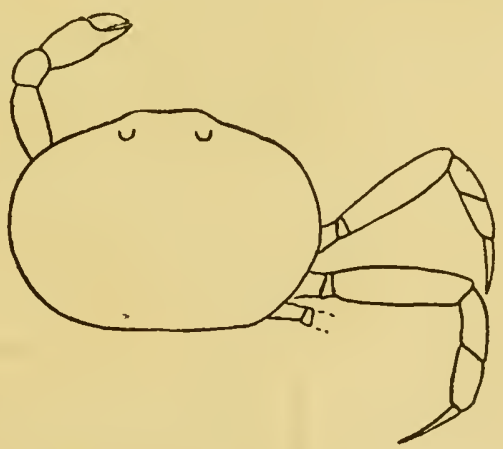

Fig. 8.-Scleroplax granulata Rathbun. $q, \times 5$, Puget Sound.

"From Bodega Bay, Cal. to Ensenada, Lower Cal." (Rathbun). I have seen no specimens of this species from Monterey, although several are in the collection from Puget Sound.

\section{Genus CRYPTOPHRYS Rathbun.}

Cryptophrys Rathbun, Proc. U. S. Nat. Mus., xvi, 250, I893. (Type-Cryptophrys concharum Rathbun). 


\section{Cryptophrys concharum Rathbun.}

Cryptophrys concharum Rathbun, Proc. U. S. Nat. Mus., xvi, 250, 1893.-Holmes,

Occas. Papers Calif. Acad. Sci., vii, 96, 1900.-Rathbun, H. A. E., x, 188, 1904.

"From Puget Sound to San Diego, Cal." (Rathbun). I have a single somewhat damaged specimen which I would place here were it not for the undoubted presence of three joints in the palp of the maxilliped. It is possibly new but on account of its condition I am unwilling to describe it.

\section{Genus OPISTHOPUS Rathbun.}

Opisthopus Rathbun, Proc. U. S. Nat. Mus., xvi, 251, 1893. (T'ype-Opisthopus transversus Rathbun).

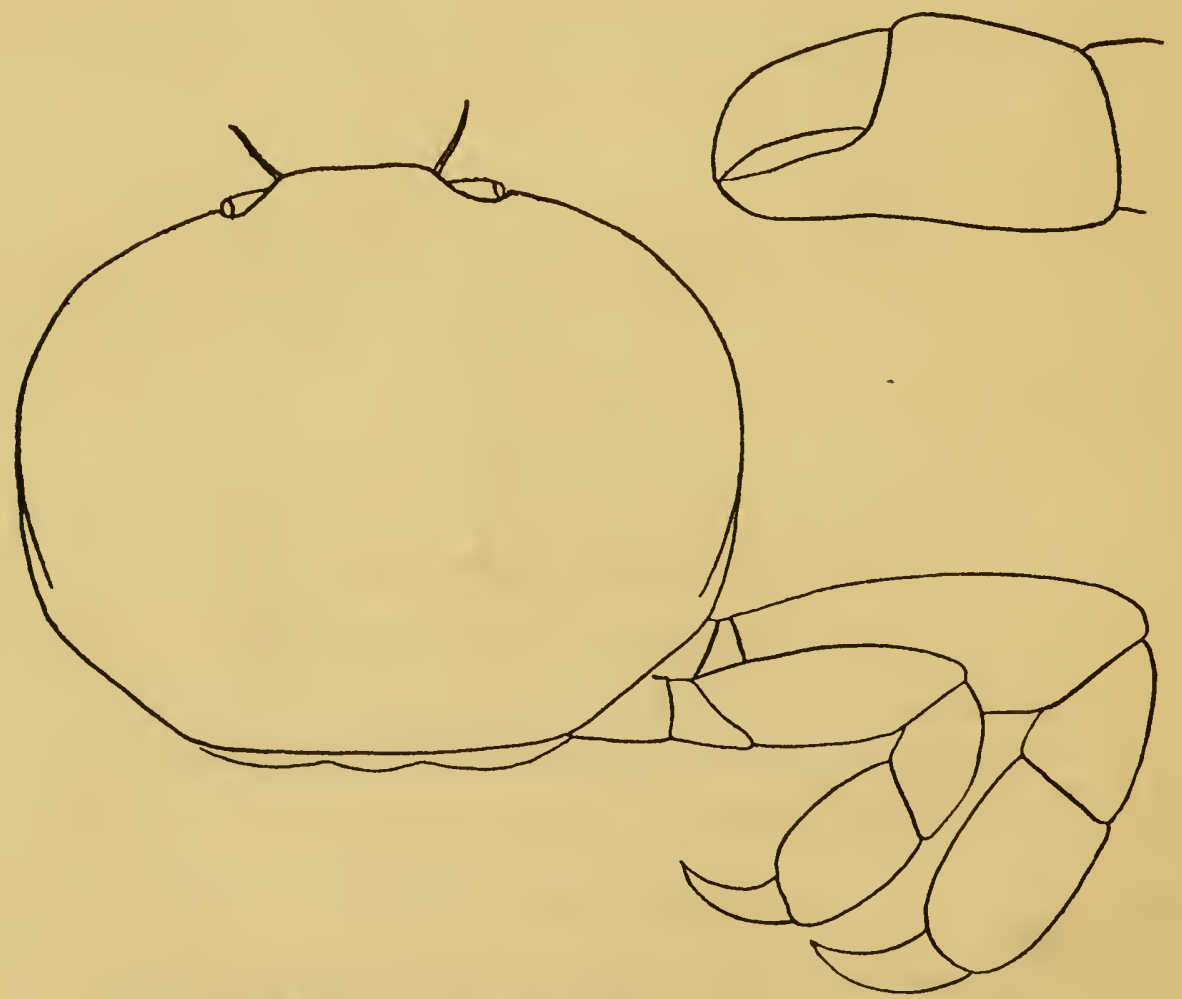

Fig. 9.-Opisthopus transversus Rathbun. \&, x6, Monterey Bay, Cal. 


\section{Opisthopus transversus Rathbun.}

Opisthopus transversus Rathbun, Proc. U. S. Nat. Mus., xvi, 252, 1893.-Holmes, Occas. Papers Calif. Acad. Sci., vii, 97, 1900.-Rathbun, H. A. E., x, I88, 1904.

There are numerous specimens of this species in the collection in part from Stichopus californicus, a common Holothurian, and Lucapina crenulata, the large key-hole limpet. The distinctness of the suture between the ischium and merus of the outer maxilliped varies considerably. All have a more or less clearly defined patch of pubesence along a portion of the antero-lateral margin. The abdomen in the females at hand varies from a width greater than that of the carapace to a size no greater than that of the male. This does not seem wholly due to immaturity as some of the females with narrow adbomens are carrying eggs. A tendency in the hand to approach in shape that of the male accompanies the narrow abdomen.

\section{Family GRAPSID平.}

Key to genera.

a. Carapace considerably broader than long.

$b$. Carapace transversely striated, external maxillipeds with a wide rhomboidal gape between them.

Pachygrapsus

$b b$. Carapace smooth, external maxillipeds closely approximated along inner edge.

aa. Carapace as long or longer than broad.

Hemigrapsus

Planes

\section{Genus PACHYGRAPSUS Randall.}

Pachygrapsus Randall, Jour. Acad. Nat. Sci. Phila., viii, 127, 1839 (Type-Pachygrapsus crassipes Randall).

\section{Pachygrapsus crassipes Randall.}

Plate XIII, fig. 4I.

Pachygrapsus crassipes Randall, Journ. Acad. Nat. Sci. Phila., viii, I26, I839.Holmes, Occas. Papers Calif. Acad. Sci., vii, 79, 1900, and synonymy.-Rathbun, H. A. E., x, 189, 1904. 
This is perhaps the most common crab on the southern part of the bay where the shores are rocky. It is never found on sandy beaches, but seems to prefer the rocks where it may be found running actively about between or above tides and feeding on cast up fish or other refuse.

General color in life a very dark red with a variable amount of whitish, which is sometimes almost entirely absent and again gives to the whole a light shade. A line of the light color is usually present in front of each of the strix of the carapace, and spots in the intestinal and cardiac regions. The ambulatory legs are similar in color to the carapace; the chelipeds are generally tan colored veined with red. The thin cuticle at the joints is a livid green.

In the series examined no marked variation was noted.

\section{Genus HEMIGRAPSUS (Dana).}

Hemigrapsus Dana, Proc. Acad. Nat. Sci. Phila., v, 247 and 250, 1851.-Dana, Am. Journ. Sci., (2) xii, 283, I85I (Type-Hemigrapsus crassimanus Dana).

Key to species.

a. Ambulatory legs smooth, hands with red spots, front sinuous.

H. nudus

aa. Ambulatory legs hairy, hands without spots, front lobed.

$H$. oregonensis

\section{Hemigrapsus nudus (Dana).}

Plate XIV, fig. 42.

Pseudograpsus nudus Dana, Proc. Acad. Nat. Sci. Phila., 249, 1851.

Brachynotus nudus Holmes, Occas. Papers Calif. Acad. Sci., vii, 8I, 1900.

Hemigrapsus nudus Rathbun, H. A. E., x, $189,1904$.

A very common crab found on rocky shores with Pachygrapsus crassipes. Color in life a very dark purple marked with more or less white or creamish. The chief of these markings occur in the $\mathrm{H}$-shaped depression in the center of the carapace and in the pits lying anterior to it. Ambulatory legs similar to carapace; chelipeds lighter, marked with numerous small spots of darker red. Under parts whitish. Color in alcohol similar, fading only after a considerable time. The color of adults is very uniform, young somewhat more variable. 


\section{Hemigrapsus oregonensis (Dana).}

Plate XIV, fig. 43.

Pseudograpsus oregonensis Dana, Proc. Acad. Nat. Sci. Phila., 248, $185 \mathrm{I}$.

Brachynotus oregonensis Holmes, Occas. Papers Calif. Acad. Sci., vii, 82, 1900.

Hemigrapsus oregonensis Rathbun, H. A. E., x, I89, 1904, and synonymy.

This species is scarce on the southern side of Monterey Bay seeming, as noted by Holmes, to prefer mud flats, where, as in San Francisco Bay, they exist in almost incredible numbers. It is considerably smaller than nudus.

Color in life a light grey marked with minute blackish or dark blue spots which are more numerous in some regions than in others. Legs lighter, marked with similar spots; hands of chelipeds whitish, without spots.

\section{Genus PLANES Bowdich.}

Planes Bowdich, Excursions in Madeira and Porto Santo, pp. xi and 15, pl. xii, figs. $2 a, 2 b, 1825$.

\section{(Planes minutus (Linnaeus).)}

Plate XIV, fig. 44.

Cancer minutes Linnaeus, Syst. Nat. Edit., xii, 1048, I766.

Nautilograpsus minutus Kingsley, Proc. Acad. Nat. Sci. Phila., 202, I880.

Planes minutes Rathbun, H. A. E., x, 189, 1904.

This widely distributed pelagic species has been reported from off the coast of California, and though I know of no record from Monterey Bay, it has been included for completeness. 


\section{BIBLIOGRAPHY.}

No extensive citation of literature has seemed necessary in view of the small number of papers appearing since the full bibliography given by Holmes. For this reason the synonymy of each species has been limited usually to the original description, a citation of Holmes and reference to such subsequent papers of importance as have been met with.

Benedict, James E.-The Anomuran Collections made by the "Fish Hawk" Expedition to Porto Rico: Bulletin U. S. Fish Commission for 1900, vol. $\mathrm{xx}$, part 2, p. 129, 1902 .

Borradaile, L. A.-On the Classification of the Decapod Crustaceans: Annals and Magazine of Nat. His., 7th series, vol. 19, p. 457, 1907.

Gerstecker, A. and Ortmann, A. E.-Crustacea: Klassen und Ordnungen des Thier-Reichs, vol. 5, parts I and 2, r866-I90I.

Holmes, S. J.-Synopsis of California Stalk-Eyed Crustacea : Occasional Papers of the California Academy of Sciences, No. 7, 1900. Full bibliography.

Rathbun, MARy J.-Synopses of North-American Invertebrates, vii, The Cyclometopous or Cancroid Crabs of North America: Am. Nat., vol. xxxiv, p. I3I, 1900; $x$, The Oxyrhynchous and Oxystomatous Crabs of North America, loc. cit., p. 503, I900; xi, The Catometopous or Grapsoid Crabs of North America, loc. cit., p. 583, 1900.

- The Brachyura and Macrura of Porto Rico: Bulletin U. S. Fish Commission for 1900, vol. xx, part 2, p. 1, 1902.

Decapod Crustaceans of the Northwest Coast of North America: Harriman Alaska Expedition, vol. x, 1904.

The Brachyura and Macrura of the Hawaiian Islands: Bulletin U. S. Fish Commission for 1903, part 3, p. 827, 1906.

Stimpson, William-Report on the Crustacea (Brachyura and Anomura) Collected by the North Pacific Exploring Expedition, 1853I856: Smithsonian Miscellaneous Collection, vol. xliv, 1907. 


\section{EXPLANATION OF PLATES}

All of the plates are from photographs taken by the author of specimens in the Leland Stanford Junior University invertebrate nuseum. As far as possible the figures are natural size and from specimens obtained in Monterey Bay; the legend of the individual plates will serve to distinguish exceptions to this general statement. 


\section{Plate I.}

Fig. I. Dromidia segnipes new species. , cotype ventral view, x 2 . Monterey Bay, Cal.

Fig. 2. Dromidia segnipes new species. Same specimen, dorsal view. The pubesence has been removed from the right half of the carapace to show the lateral teeth.

Fig. 3. Randallia ornata (Randall). ๙ิ, nat. size. Monterey Bay, Cal. 


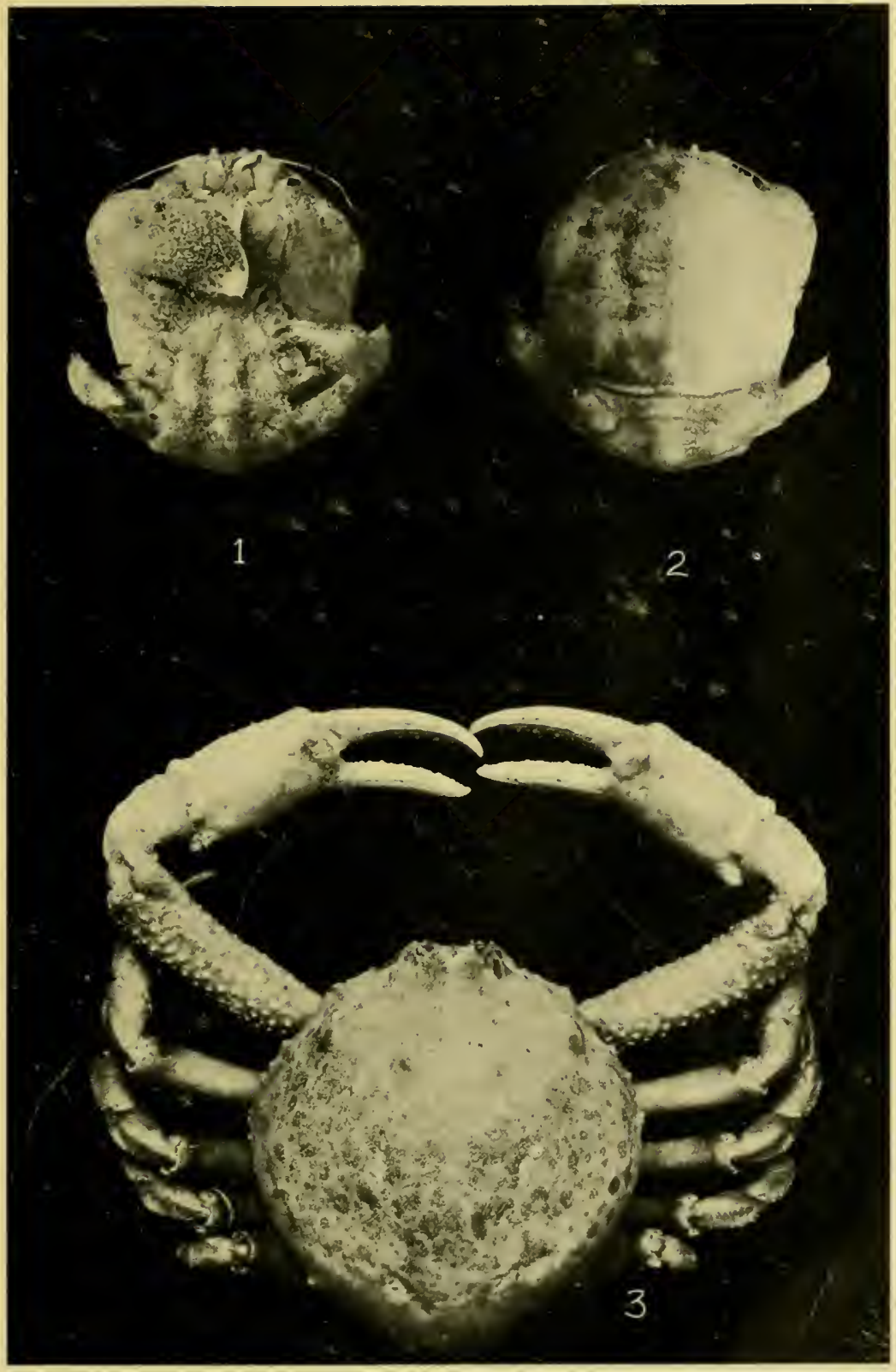



Plate II.

Fig. 4. Heterocrypta occidentalis (Dana). \&, nat. size. Monterey Bay, Cal.

Fig. 5. Heterocrypta occidentalis (Dana). o, nat. size. Monterey Bay, Cal.

Fig. 6. Podochela hemphillii (Lockington). ô, x 2. Monterey Bay, Cal. 


Plate III.

Fig. 7. Erileptus spinosus Rathbun.

$\delta$, x 3. Catalina Island, Cal.

Fig. 8. Dasygyius tuberculatus (Lockington). ô, x 2. Monterey Bay, Cal.

Fig. 9. Epialtus productus Randall.

\&, nat. size. Monterey Bay, Cal. 


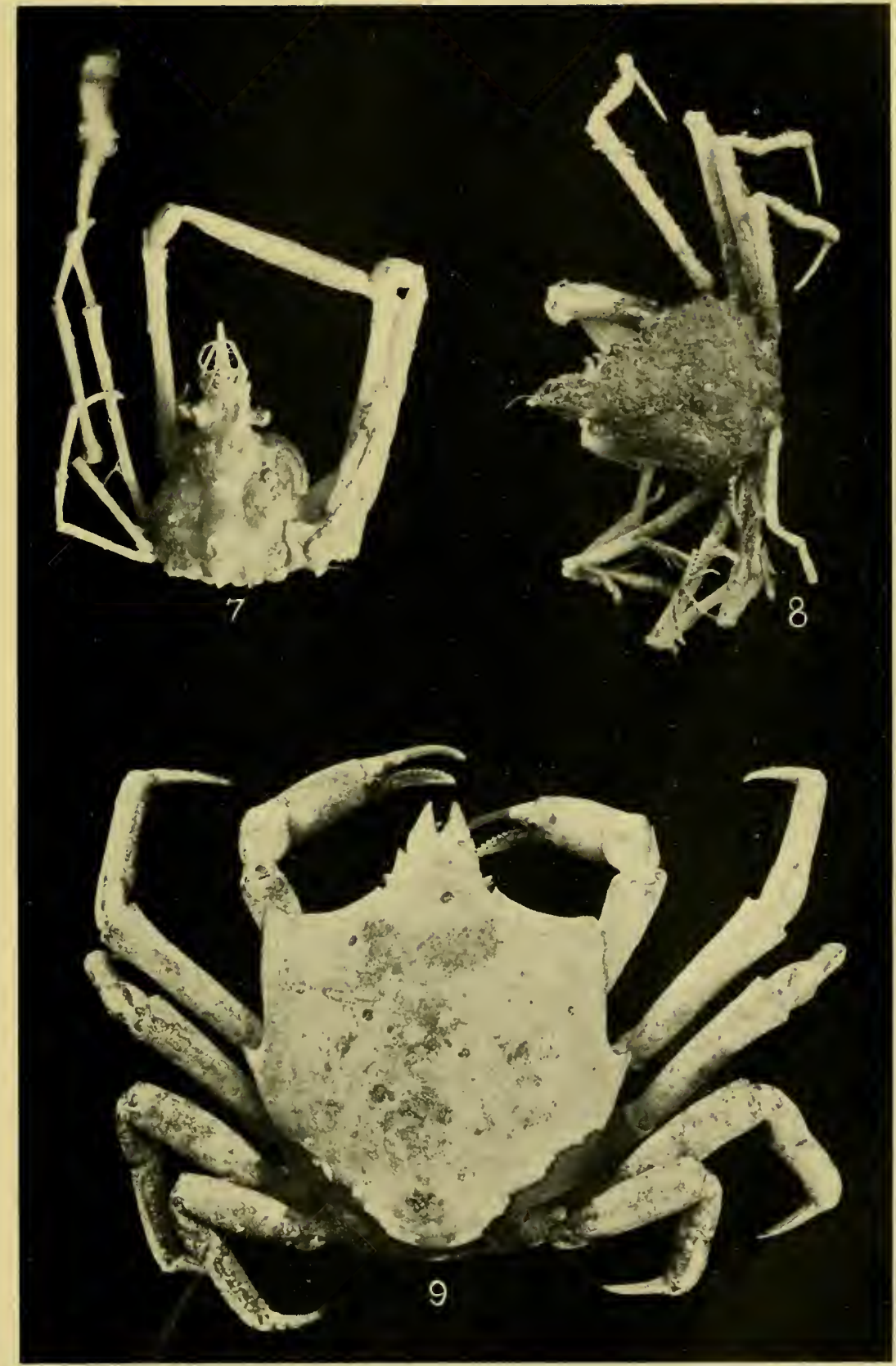





\section{Plate IV.}

Fig. 10. Pugettia gracilis Dana. $\hat{\delta}$, nat. size. Sitka, Alaska.

Fig. II. Pugettia richii Dana.

$\hat{\delta}$, nat. size. "West coast North America"

(U. S. Nat. Museum specimen).

Fig. 12. Mimulus foliatus Stimpson.

ô, nat. size. Monterey Bay, Cal.

Fig. 13. Mimulus foliatus Stimpson.

क, nat. size. Monterey Bay, Cal. 


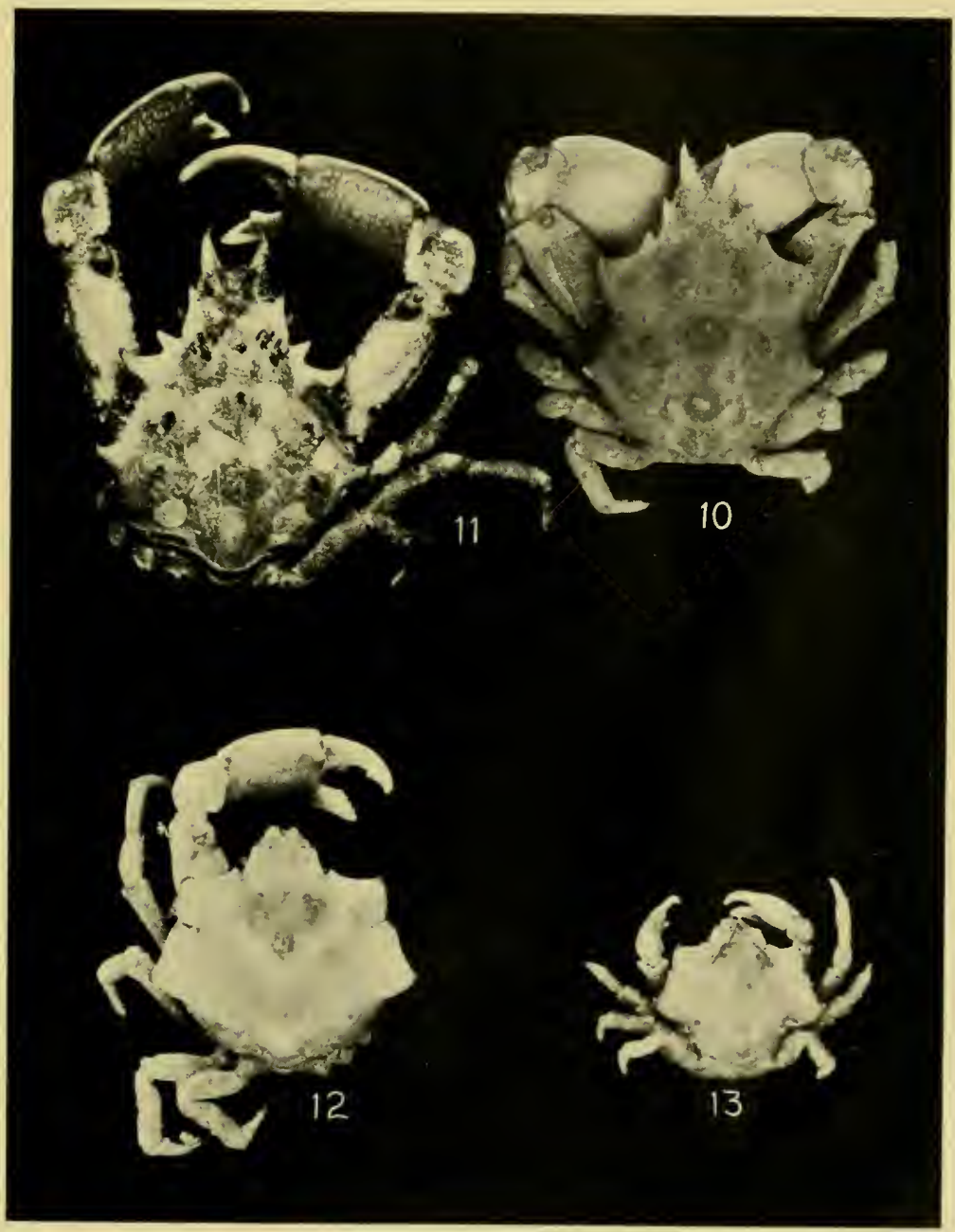





\section{Plate V.}

Fig. I4. Loxorhynchus grandis Stimpson. §, $\times$ I/3. Monterey Bay, Cal.

Fig. I5. Loxorhynchus crispatus Stimpson. o, x x 2 . Monterey Bay, Cal. 


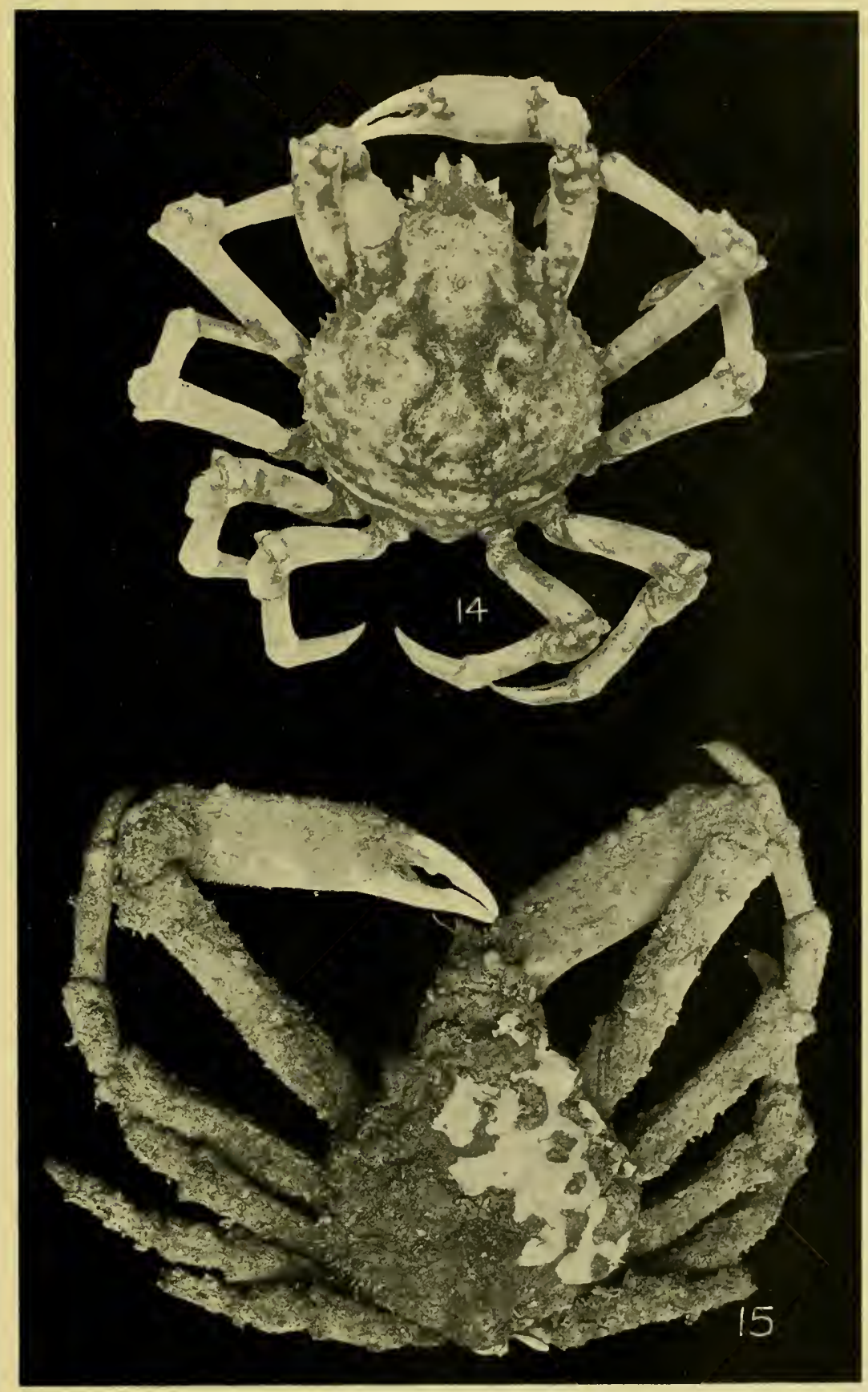






\section{Plate VI.}

Fig. 16. Chorilia longipes Dana.

o, nat. size. Albatross station No. 435I, Cal. coast off Point Loma.

Fig. 17. Scyra acutifrons Dana.

§., nat. size. Monterey Bay, Cal. 


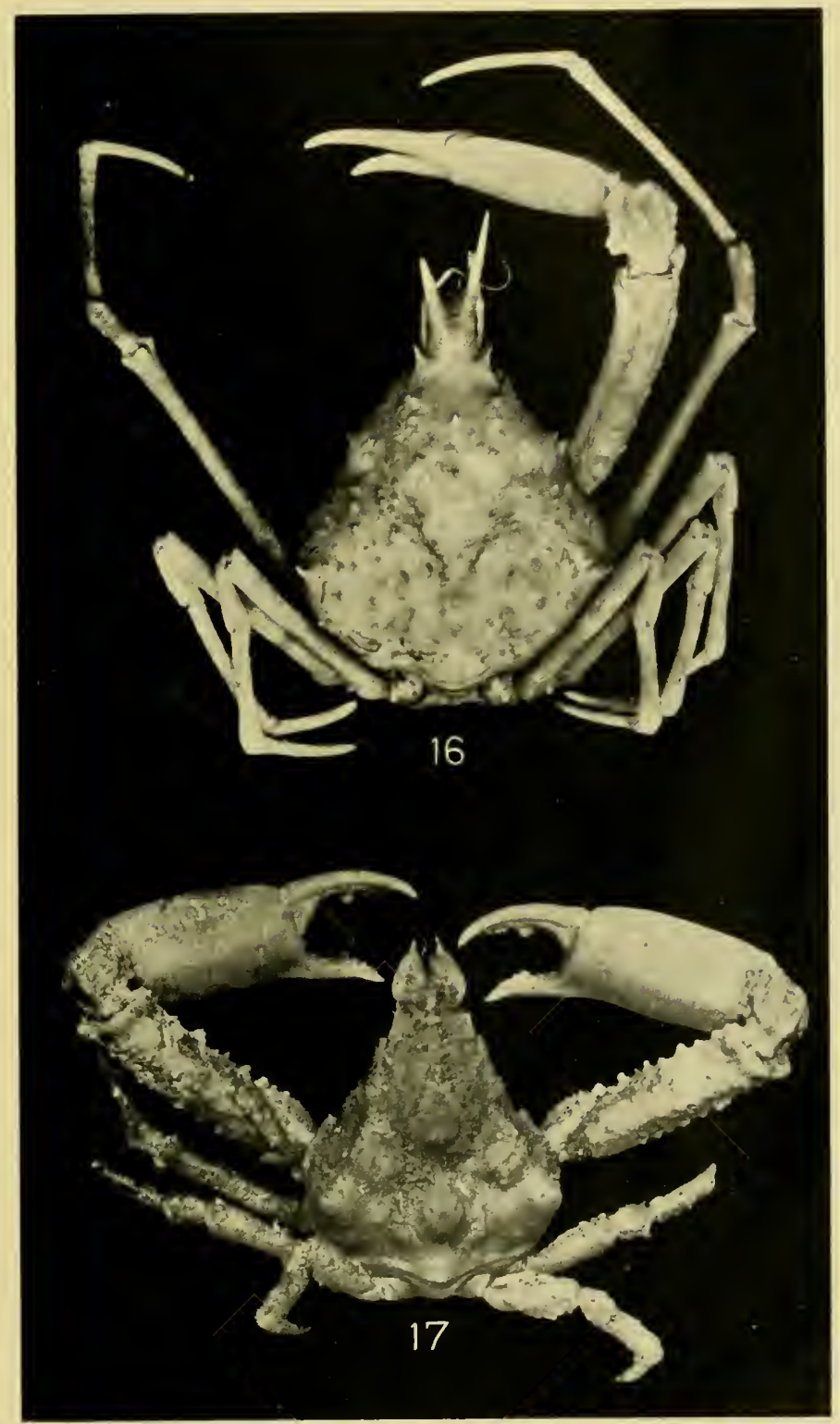




Plate VII.

Fig. I8. Rhodia parvifrons (Randall).

$\hat{o}$, nat. size. Monterey Bay, Cal.

Fig. 19. Chionoecetes tanneri Rathbun.

ô, nat. size. Seattle, Wash. 


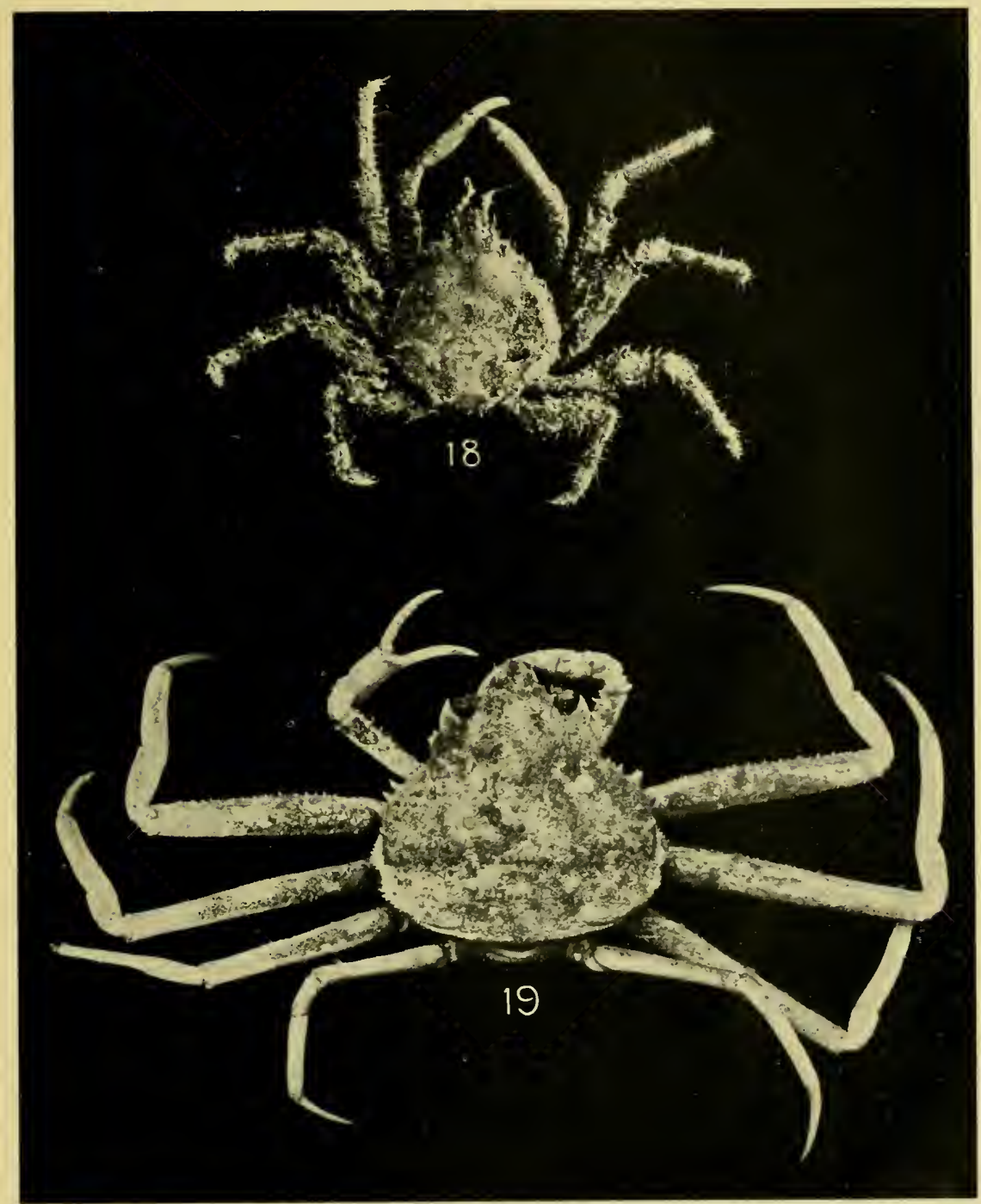



Plate VIII.

Fig. 20. Cancer productus Randall. Immature, nat. size. Monterey Bay, Cal.

Fig. 21. Cancer productus Randall. Immature, nat. size. Monterey Bay, Cal.

Fig. 22. Cancer productus Randall. Immature, nat. size. Monterey Bay, Cal.

Fig. 23. Cancer productus Randall. Immature $\&$, nat. size, showing the striping of the carapace often present in young individuals. Monterey Bay, Cal.

Fig. 25. Cancer productus Randall. Adult of, x 1/2. Monterey Bay, Cal. 

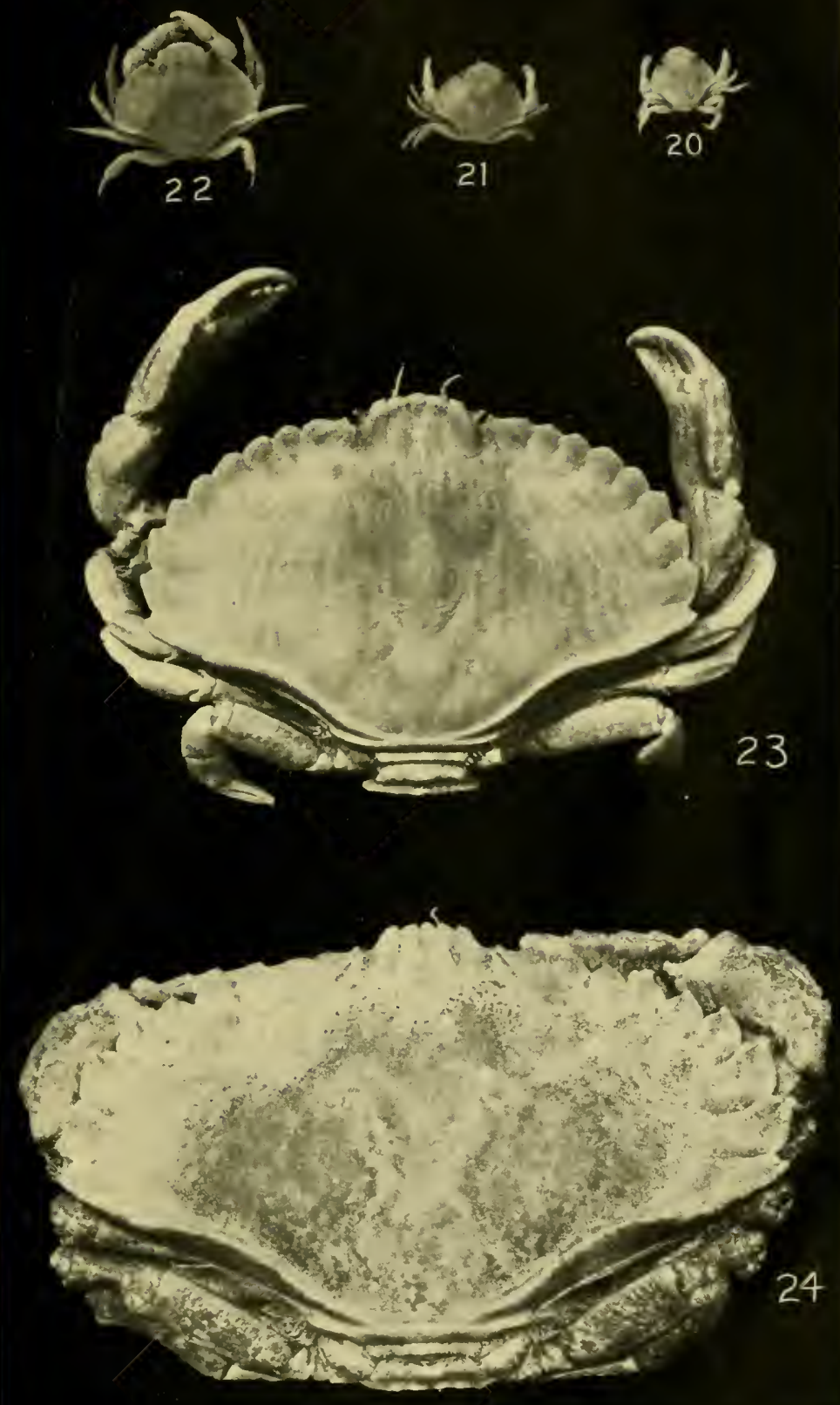

Plate IX.

Fig. 25. Cancer magister Dana.

Egg-bearing $q, x^{1} / 2$. San Francisco, Cal.

Fig. 26. Cancer gracilis Dana.

Immature, nat. size. Monterey Bay, Cal.

Fig. 27. Cancer gracilis Dana.

Immature, nat. size. Monterey Bay, Cal.

Fig. 28. Cancer gracilis Dana.

§, nat. size. Monterey Bay, Cal. 


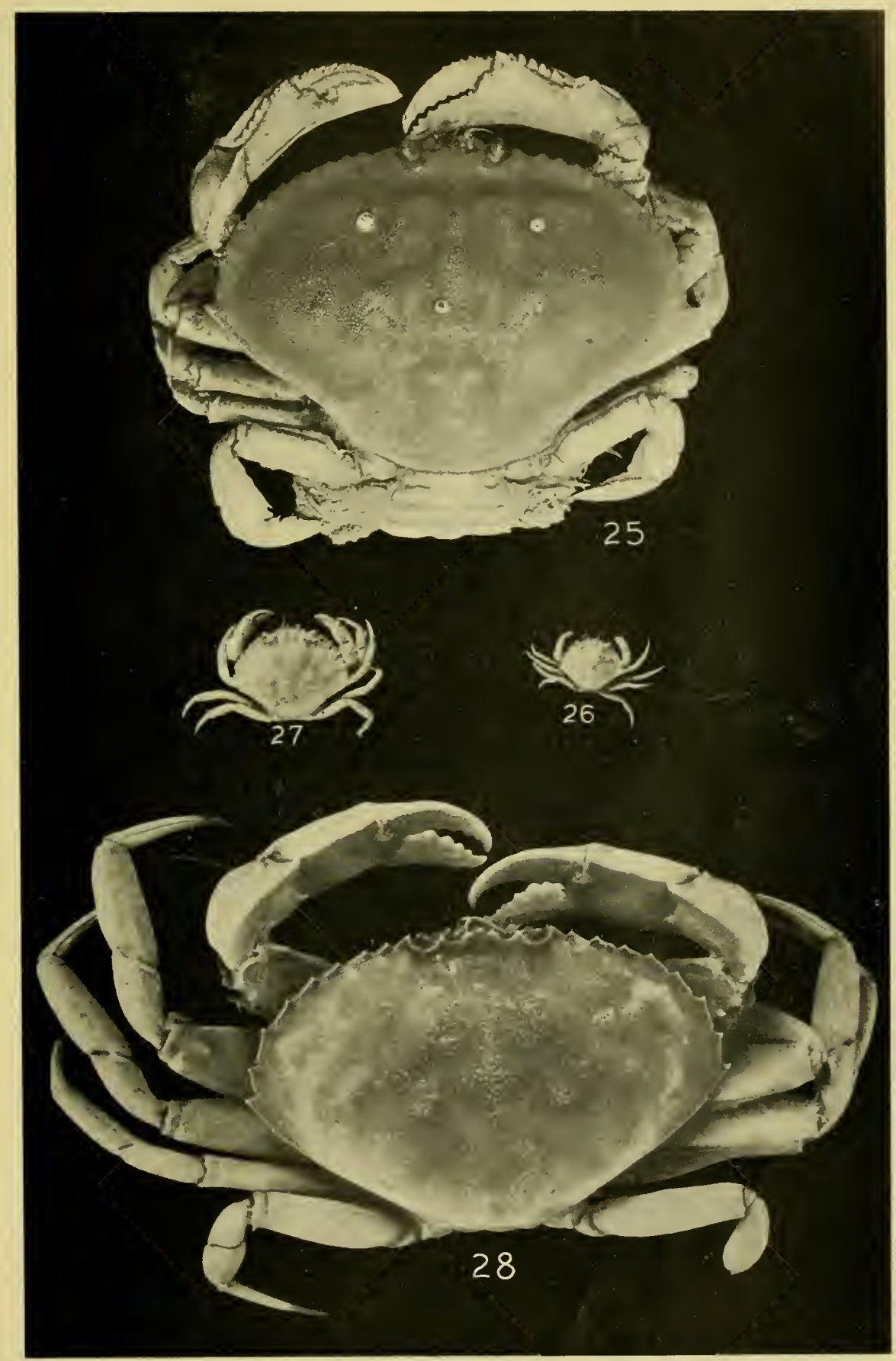




Plate X.

Fig. 29. Cancer gibbosulus (de Haan). ô, nat. size. Monterey Bay, Cal.

Fig. 3o. Cancer jordani Rathbun. $\hat{o}$, nat. size. Monterey Bay, Cal.

Fig. 3r. Cancer antennarius Stimpson. Adult $\hat{o}, x \frac{1}{2}$. Monterey Bay, Cal. 


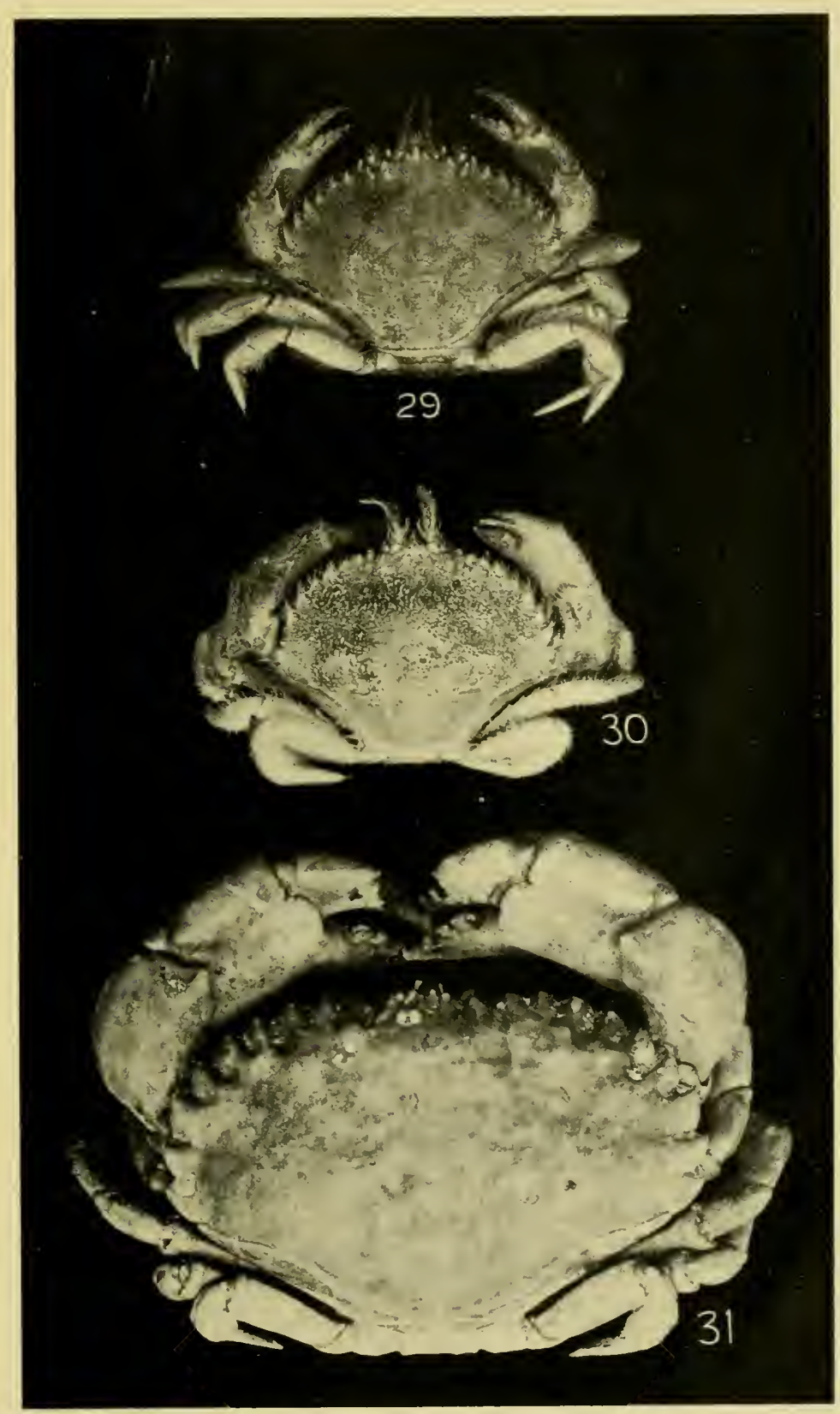






\section{Plate XI.}

Fig. 32. Cancer antennarius Stimpson. \&, nat. size. Monterey Bay, Cal. The extreme pubesence here shown is not typical of the species.

Fig. 33. Cancer anthonyi Rathbun. o, $\mathrm{x} \mathrm{x} / 2$. San Diego, Cal.

Fig. 34. Cancer oregonensis (Dana). $\$$, nat. size. Orca, Prince William Sound, Alaska. 


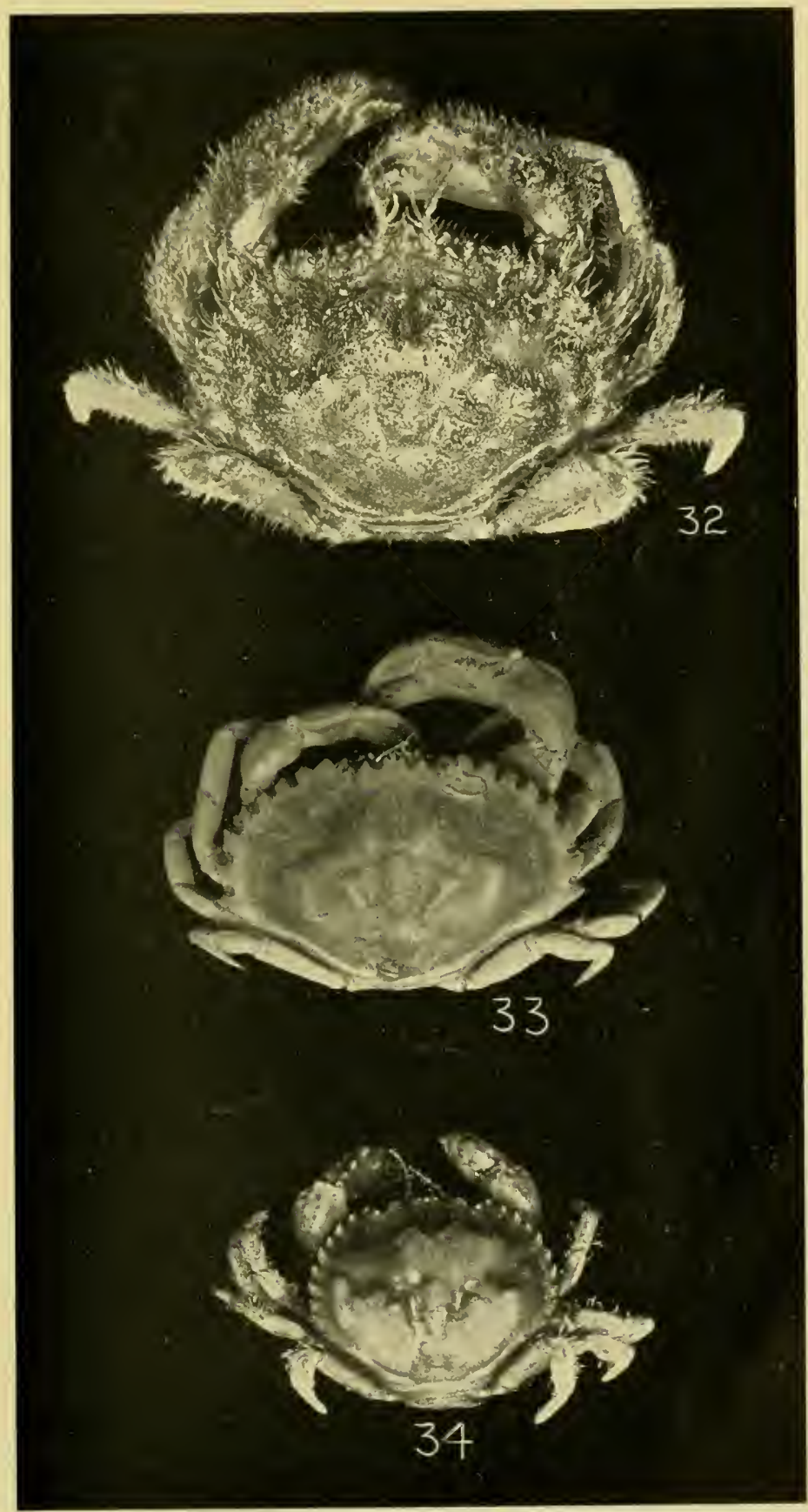






\section{Plate XII.}

Fig. 35. Portunus xantusii (Stimpson). $\hat{\jmath}$, nat. size. San Diego, Cal.

Fig. 36. Cycloxanthops novemdentatus (Lockington). $\hat{o}$, nat. size. Monterey Bay, Cal.

Fig. 37. Lophopanopeus bellus (Stimpson). $\hat{o}$, nat. size. Monterey Bay, Cal.

Fig. 38. Lophopanopeus heathii Rathbun. $\hat{o}$, nat. size. Monterey Bay, Cal.

Fig. 39. Lophopanopeus diegensis Rathbun. $\hat{o}$, nat. size. Monterey Bay, Cal. 


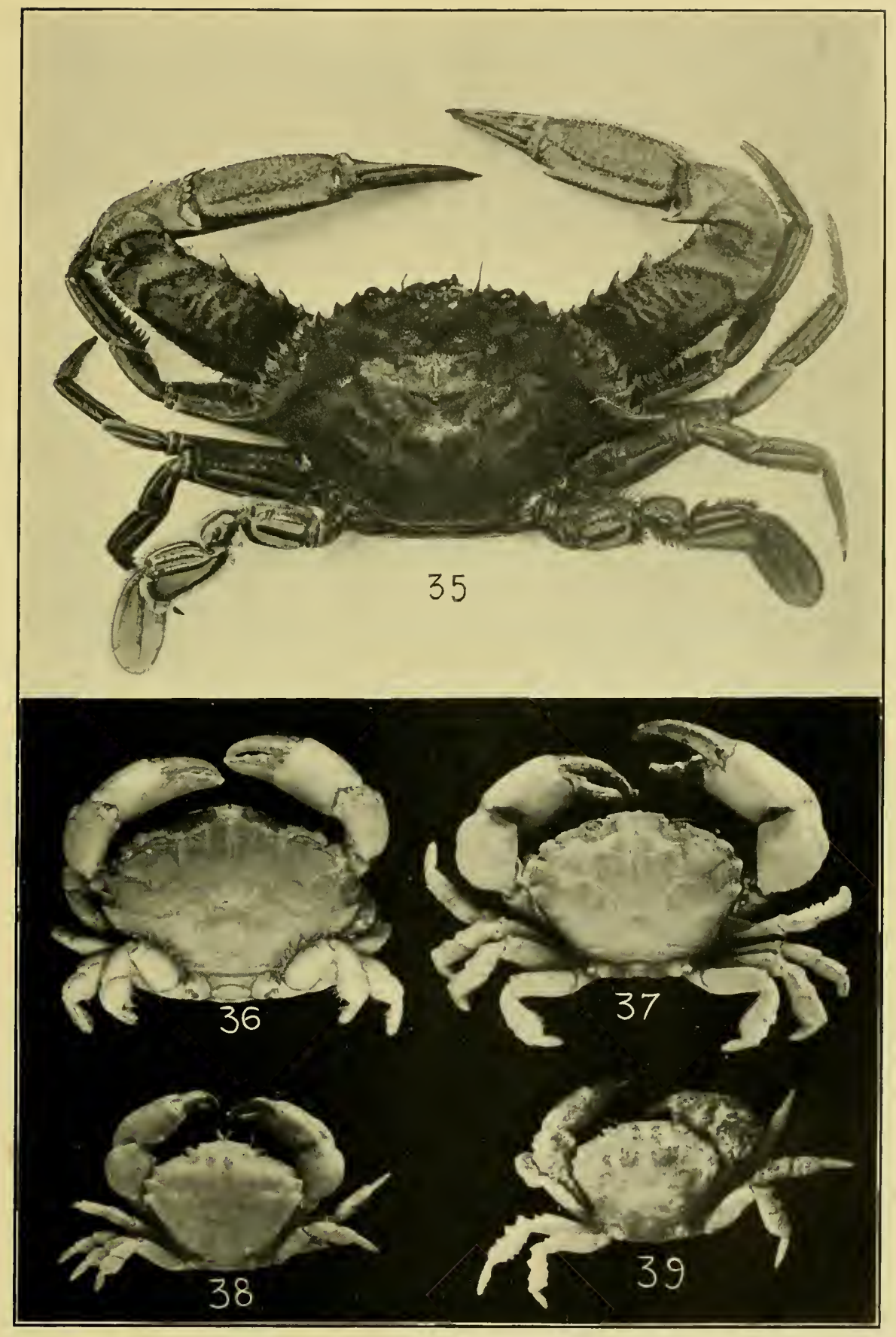






\section{Plate XIII.}

Fig. 40. Xanthias taylori (Stimpson). \&, nat. size. Monterey Bay, Cal.

Fig. 4I. Pachygrapsus crassipes Randall. ô, nat. size. Monterey Bay, Cal. 


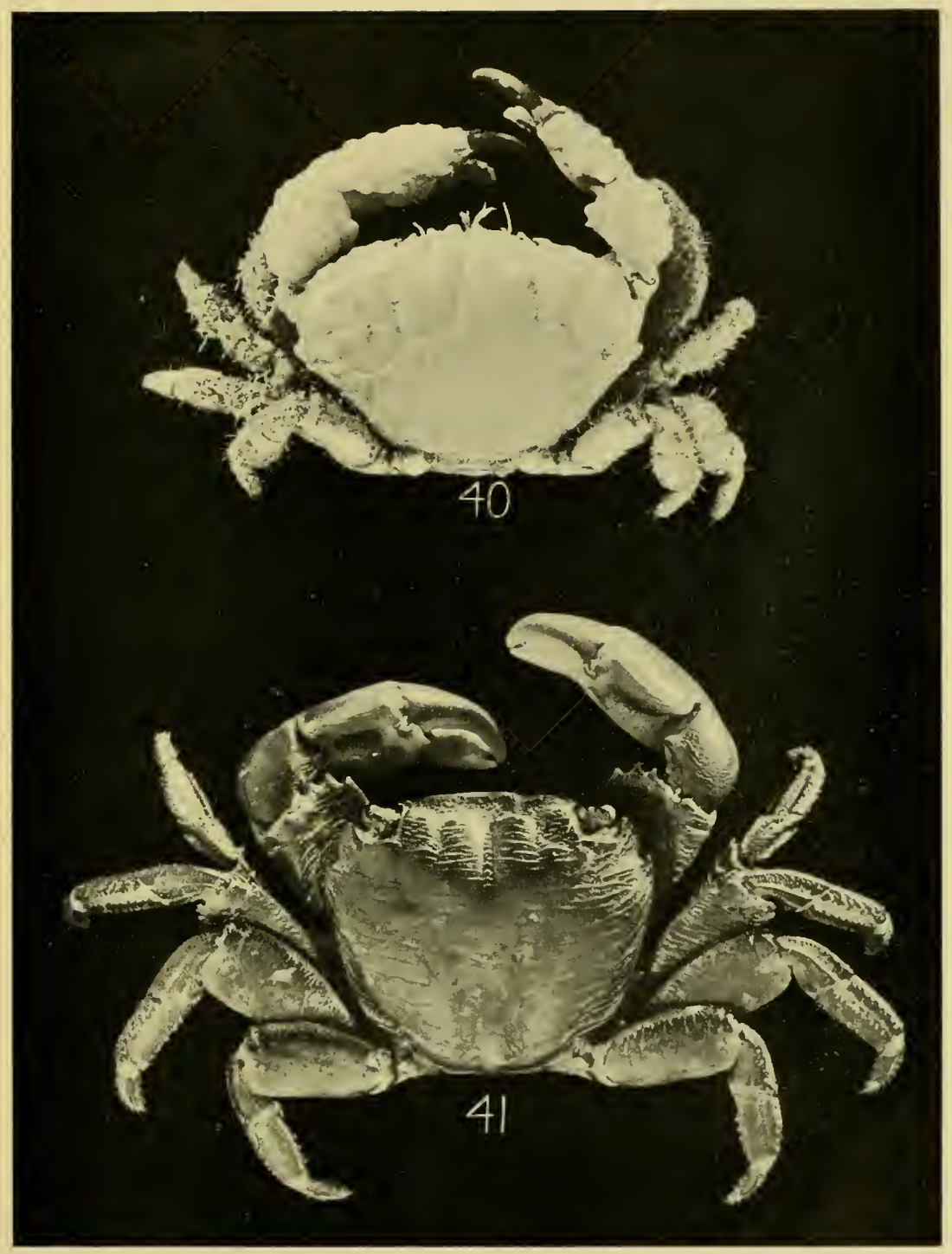






\section{Plate XIV.}

Fig. 42. Hemigrapsus nudus (Dana). o, nat. size. Monterey Bay, Cal.

Fig. 43. Hemigrapsus oregonensis (Dana). ô, nat. size. Monterey Bay, Cal.

Fig. 44. Planes minutus (Linnaeus). Egg-bearing o, nat. size. From floating sea turtle near the Galapagos Islands. 


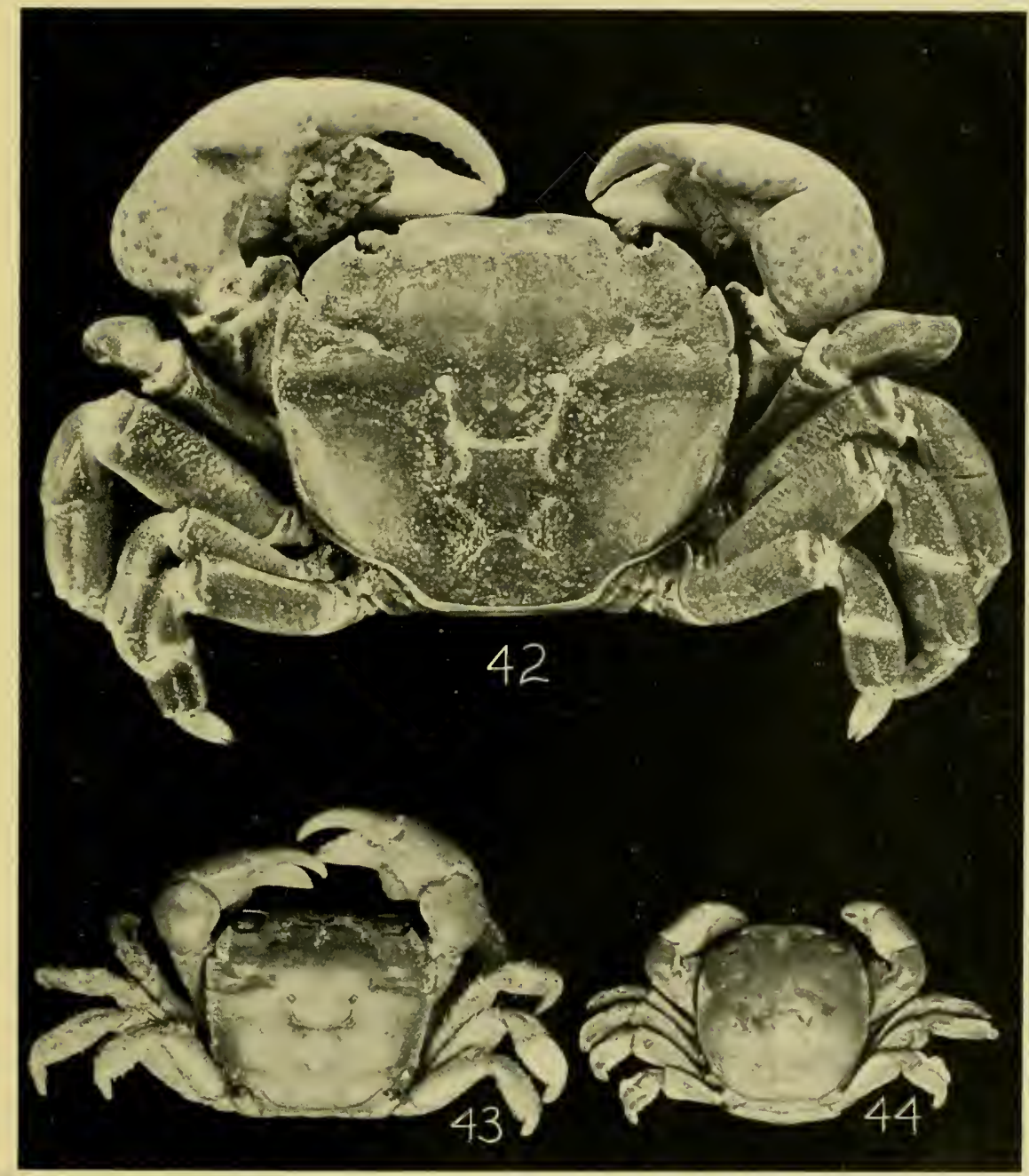





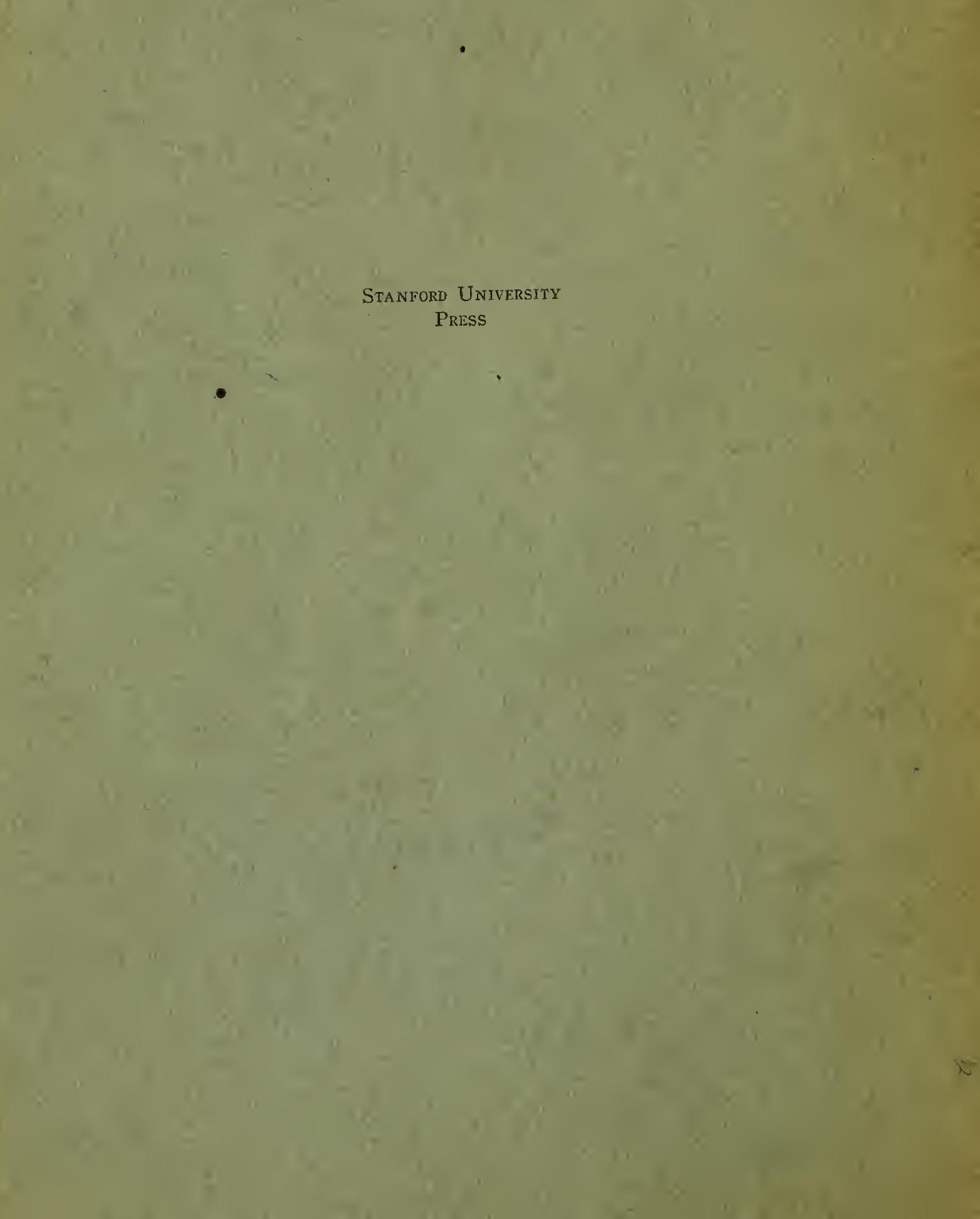





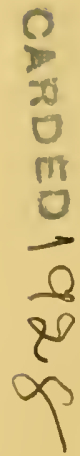





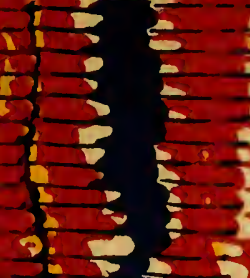

12,2

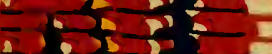

in:?

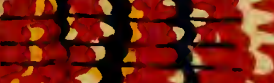

$\frac{1}{3} \div-5: 5$

$26=?$

$\rightarrow 28$

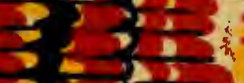

$\Rightarrow \frac{1}{5}$

$\rightarrow i^{2}$

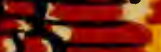

$+2$

$3 \rightarrow \frac{2}{2}$

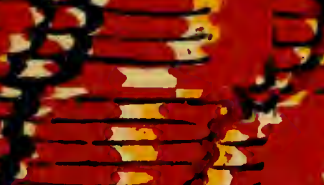

$\frac{5}{2}+\frac{5}{2}-5$ $25-1$

$\therefore$ :

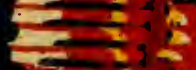

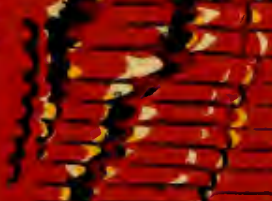

$\frac{1}{2}$

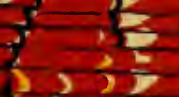

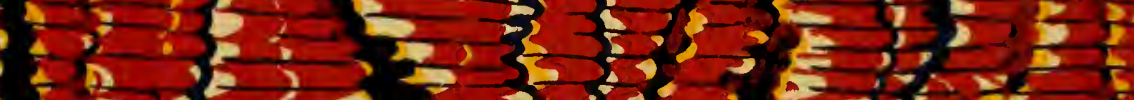

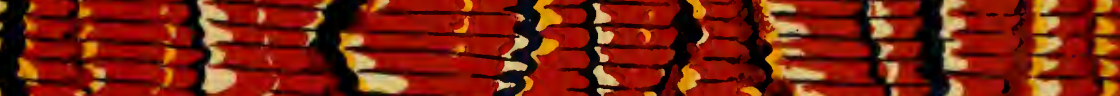

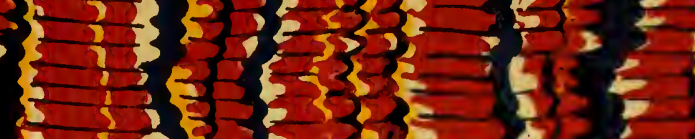

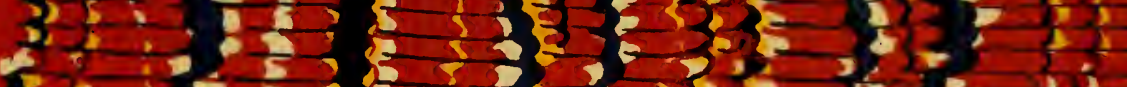

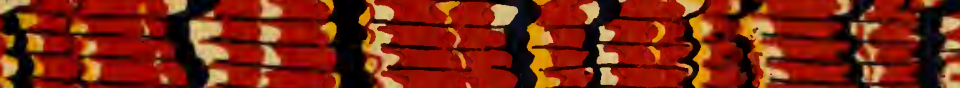

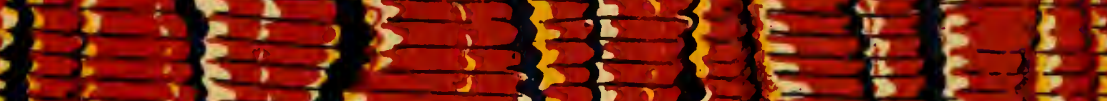

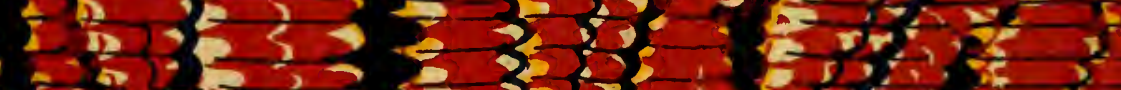

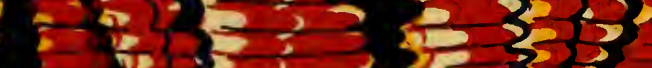

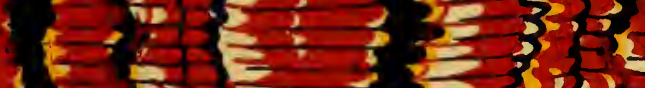

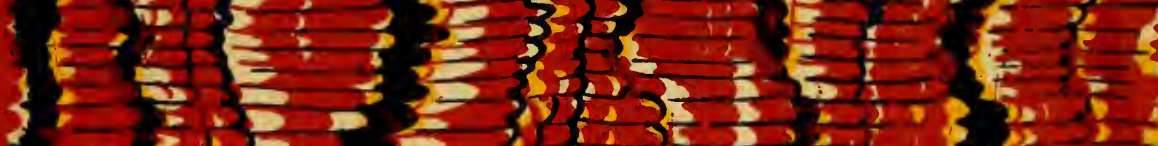

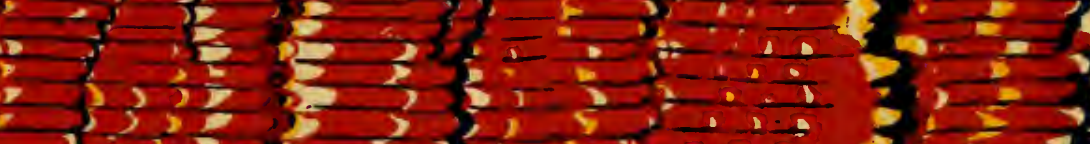

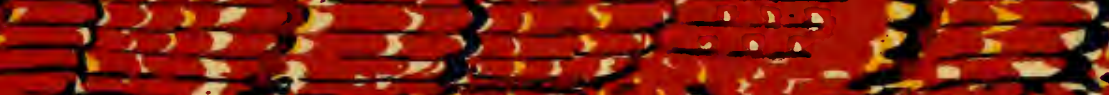

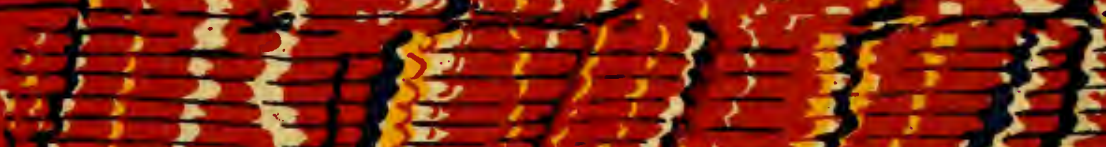

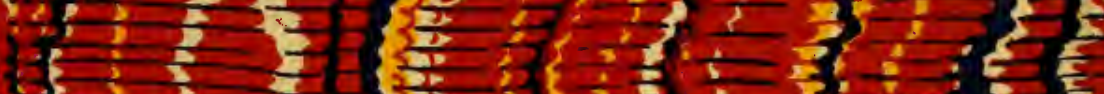

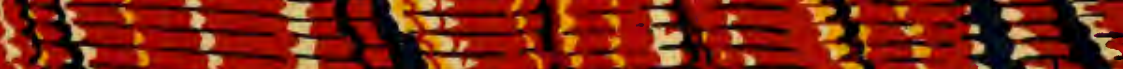

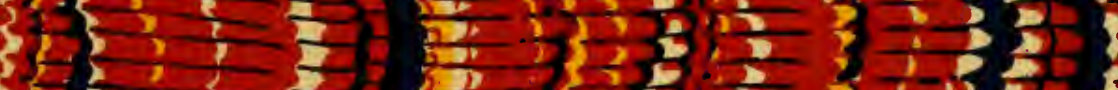

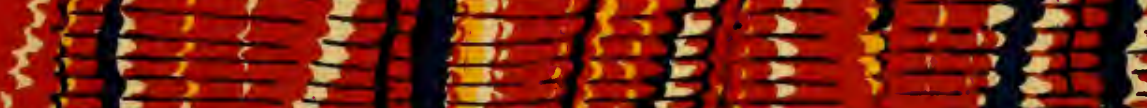

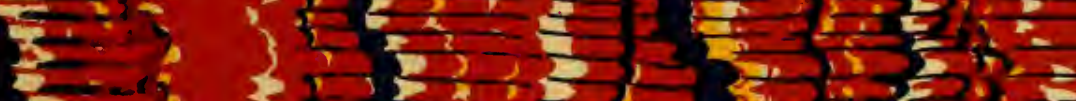

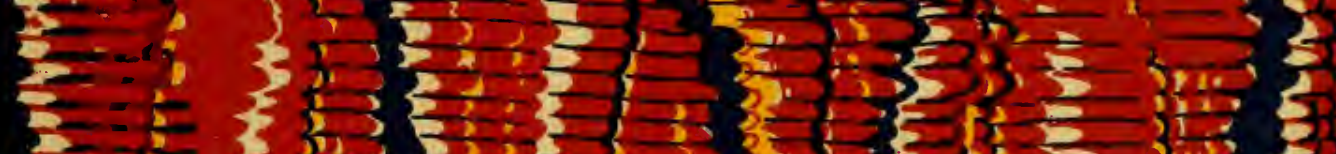

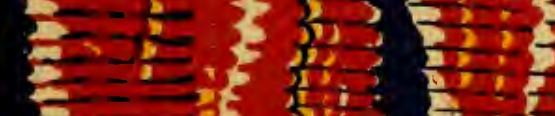

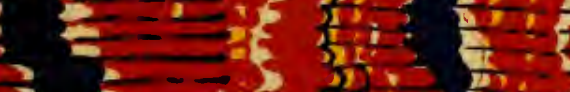

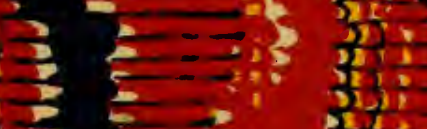

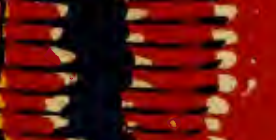
,

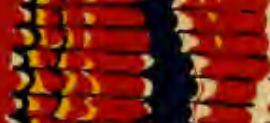
$3 \frac{3}{2}, 3 \frac{2}{2}$ $i \sum i \frac{2}{3}$

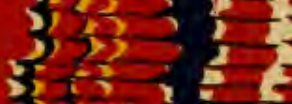
3
$\frac{3}{3-3} \sum^{2}=3$

$3 \frac{5}{2}-3=$

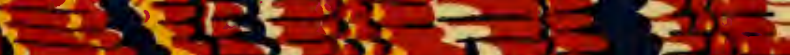

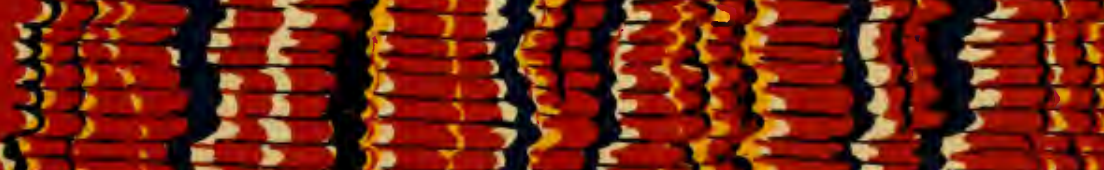

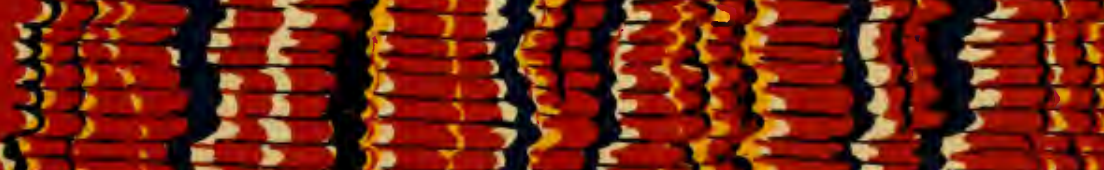
3. 35

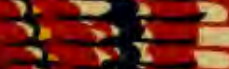

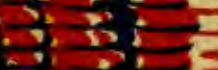

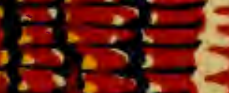

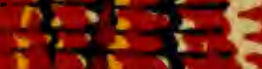

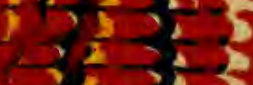

3 i

3) $5 \div 35$

;2-3: $: 5$

$z^{2}-\frac{1}{2} ; \frac{3}{3}$

i.

$\div 2=1$

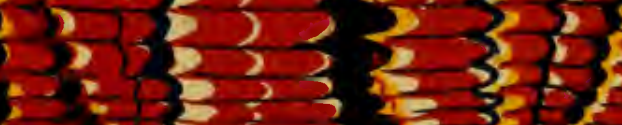

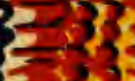

$=4232$ 
